Pontifícia Universidade Católica $_{\text {a }}$

DO RIO DE JANEIRO

Kárita Ressiguier Chagas Viana

Estudo do sistema construtivo em alvenaria estrutural

na cidade do Rio de Janeiro face aos conceitos e construção sustentável

Dissertação de Mestrado

Dissertação apresentada ao Programa de Pósgraduação em Engenharia Civil da PUC-Rio como requisito parcial para obtenção do título de Mestre em Engenharia Civil.

Orientador: Prof. Celso Romanel Co-orientador: Prof. Emil de Souza Sánchez Filho 
Pontifícia Universidade Católica $_{\text {a }}$

DO RIO DE JANEIRO

Kárita Ressiguier Chagas Viana

\title{
Estudo do sistema construtivo em alvenaria estrutural na cidade do Rio de Janeiro face aos conceitos de construção sustentável
}

Dissertação apresentada como requisito parcial para obtenção do título de Mestre em Engenharia Urbana e Ambiental (opção profissional) pelo Programa de Pós-Graduação em Engenharia Urbana e Ambiental da PUC-Rio. Aprovada pela Comissão Examinadora abaixo assinada.

\author{
Prof. Celso Romanel \\ Presidente / Orientador \\ Departamento de Engenharia Civil - PUC-Rio
}

Prof. Emil de Souza Sánchez Filho

Co-orientador

Departamento de Engenharia Civil - UFF

Prof. Júlio Jerônimo Holtz Silva Filho

Departamento de Engenharia Civil - PUC-Rio

Prof. Osvaldo Luiz de Carvalho Souza

Departamento de Arquitetura e Urbanismo do Instituto de Tecnologia -

UFRRJ

Prof. José Eugenio Leal

Coordenador Setorial de Pós-Graduação do Centro Técnico Científico - PUC-Rio

Rio de Janeiro, 09 de dezembro de 2013. 
Todos os direitos reservados. É proibida a reprodução total ou parcial do trabalho sem autorização da universidade, da autora e do orientador.

Kárita Ressiguier Chagas Viana

Graduou-se em Arquitetura e Urbanismo na UFRJ (Universidade Federal do Rio de Janeiro) em 2006. Concluiu a XXV Jornada de Iniciação Científica nos temas "Manual de arquitetura bioclimática tropical para redução do consumo energético" e "Representação gráfica de edifícios residenciais para estudos de interação com a radiação solar" no PROURB - FAU/UFRJ em 2003. Pós graduou-se em Gestão Empresarial na Escola Politécnica da UFRJ. Atua no mercado da construção civil desde 2003, tendo exercido as funções de arquiteta de obra, arquiteta de projeto executivo, coordenadora de incorporação e membro de comitê de sustentabilidade auxiliando no desenvolvimento de ações e nesse campo para o mercado da construção civil.

Ficha Catalográfica

Viana, Kárita Ressiguier Chagas

Estudo do sistema construtivo em alvenaria estrutural na cidade do Rio de Janeiro face aos conceitos e construção sustentável / Kárita Ressiguier Chagas Viana; orientador: Celso Romanel; co-orientador: Emil de Souza Sánchez Filho. - 2013.

131 f. : il. (color.); $29,7 \mathrm{~cm}$

Dissertação (mestrado) - Pontifícia Universidade Católica do Rio de Janeiro, Departamento de Engenharia Civil, 2013.

Inclui bibliografia

1. Engenharia civil - Teses. 2. Sustentabilidade. 3. Construção civil. 4. Tecnologias construtivas. 5. Alvenaria estrutural. I. Romanel, Celso. II. Sánchez Filho, Emil de Souza. III. Pontifícia Universidade Católica do Rio de Janeiro. Departamento de Engenharia Civil. IV. Título. 
Ao meu marido, Daniel, pelo incentivo e apoio. 


\section{Agradecimentos}

Ao meu orientador Professor Celso Romanel e co-orientador Professor Emil de Souza Sánchez Filho pelo estímulo e parceria para a realização deste trabalho.

Ao meu marido pelo incentivo de sempre.

Aos meus pais, pela educação e carinho de todas as horas.

Aos professores que participaram da Comissão examinadora.

A todos os professores e funcionários do Departamento pelos ensinamentos e pela ajuda.

A todos os amigos e familiares que me estimularam ou me ajudaram. 


\section{Resumo}

Viana, Kárita Ressiguier Chagas; Romanel, Celso (Orientador); Filho, Emil de Souza Sánchez (Co-orientador). Estudo do sistema construtivo em alvenaria estrutural na cidade do Rio de Janeiro face aos conceitos de construção sustentável. Rio de Janeiro, 2013. 131p. Dissertação de Mestrado Departamento de Engenharia Civil, Pontifícia Universidade Católica do Rio de Janeiro.

Nesta dissertação estuda-se o sistema construtivo em alvenaria estrutural na cidade do Rio de Janeiro face aos conceitos de construção sustentável. Avalia-se esse método construtivo em seus detalhes de execução, materiais utilizados e outros benefícios na obra como redução de resíduos e ganhos em prazo de construção. Também são analisados impactos qualitativos no produto e os aspectos sociais e culturais devido as limitações técnicas do sistema bem como as legislações que têm influência. Levando-se em consideração as necessidades atuais do mercado imobiliário na busca por processos sustentáveis, foram analisadas as principais certificações. Tem-se como principal conclusão que nem sempre o processo atenderá de forma completa as necessidades de determinado empreendimento em função de algumas limitações técnicas. Do ponto de vista da sustentabilidade, o processo apresenta qualidades devido à modulação do sistema que gera menos desperdícios, porém, pode limitar a concepção de um produto diversificado e mais confortável através de soluções diferenciadas de planta e fachada, por exemplo. Mesmo que as construtoras tenham tentado utilizar o sistema em padrões médios de empreendimento, com preços de venda que giram em torno de 7.000 a 8.000 reais por metro quadrado, a solução não teve boa aceitação tanto pelos construtores como pelos clientes, e nota-se que o mesmo é utilizado em larga escala para empreendimentos de padrões populares.

\section{Palavras-chave}

Sustentabilidade; construção civil; tecnologias construtivas; alvenaria estrutural. 


\section{Abstract}

Viana, Kárita Ressiguier Chagas; Romanel, Celso (Advisor); Filho, Emil de Souza Sánchez (Co-advisor). Study of the constructive system in structural masonry in the city of Rio de Janeiro face to the concepts of sustainable construction. Rio de Janeiro, 2013. 131p. MSc. Dissertation - Departamento de Engenharia Civil, Pontifícia Universidade Católica do Rio de Janeiro.

In this thesis the use of structural masonry constructive system is investigated in light of the concepts of sustainable construction in the city of Rio de Janeiro. This study is based on the evolution and growing importance of the construction sector within Brazilian economy, and the current trend in the construction market in the search for processes that minimize impacts on the environment with rational use of natural resources.

The earliest records of civil construction activity in the city of Rio de Janeiro date from the colonial period, at a time which those activities were unregulated. In 1810 King João VI established the engineering school. The period between the late nineteenth century and early twentieth century was a time of intense economic transformation with the decay of the coffee plantations and the beginning of the industrial development.

In 1940 there was a breakthrough in civil construction in Brazil, when the sector was considered one of the most advanced of its time. In 1971 there was great progress in the sector of construction in Rio de Janeiro with the creation of BNH, Banco Nacional da Habitação, and the Law of the Real Estate Development (Lei das Incorporações).

The 90s were marked by the improvement of the qualification of the workforce, resulting in better products. The 2000s were distinguished by the boom in housing construction in the west zone and the expansion of large construction companies' landbanks. In 2008 the growth was toward the north zone, however, by the end of that year, with the peak of the global crisis known as "Subprime", the sector started suffering from a poor performance cycle until in the first half of 2009. The government program called Minha Casa Minha Vida was launched providing a better environment, with the incentive to produce one 
million new housing units. By the second half of 2009 the construction market was fully recovered.

Many companies created new brands or subsidiaries to focus their business in this new market niche, and the use of large-scale structural masonry was considered the most suitable technology to be used in this type of construction. In 2011, the sector continued to grow driven by the demand fostered by the Olympic Games and the approval of new urban zoning laws.

In this study the major projects launched in the city of Rio de Janeiro between 2005 and 2012 were mapped as well as the number of constructions that adopted structural masonry during this period.

Impacts of civil construction on the environment range from the generation of raw material to the end of the useful life of products built. As a consequence of the growth experienced by the civil construction sector and its great economic impact, principles of sustainability standards and certifications arouse aiming the achievement of sustainable development in the entire production chain.

Over the years, several international events debated on sustainability. In 1713 Carl Von Carlowitz published the first treaty on sustainable use of forest resources. In 1976 the first world conference on housing and environment was held in Canada.

The system in structural masonry is ancient and its use dates back to early human activity process. Around 4000 years before Christ structures were employed for varied purposes and materials were usually blocks of clay and stone. In the seventeenth century the system becomes a construction technology based on principles of static. Element resistance tests begun to be performed in the nineteenth and twentieth centuries. The projects were based on limited empirical calculation methods, resulting in very thick walls and slow production speed. In the 50's there was a revival of interest in structural masonry driven by the shortage of building materials in Europe, such as steel.

The use of structural masonry in Brazil began in the sixteenth century, during the colonial period; yet, the process was not rationalized. By the 70 s, the structural masonry was considered engineering technology in Brazil and projects started to be based on scientifically validated principles. With this evolution, it became more efficient and an economical alternative, although still somewhat precarious. Structural masonry achieved its consolidation with official norms in the 80s. 
Ancient definitions considered that the buildings should be formed of natural or artificial stones linked together in a stable manner by the combination of joints and mortar (or only by one of the two), capable of resisting only to compressive stresses.

Currently, buildings in structural masonry are formed by industrial blocks (ceramic or concrete) designed and sized by calculation procedures to support loads beyond their own weight and resist compression. They are linked together by the interposition of mortar and can contain rebar in concrete or mortar in horizontal and / or vertical plane. They are classified as armed, unarmed, partially armed or pre-stressed.

The structural masonry consists of four main components. The units are the basic components that define the resistance characteristics. Units can be concrete, ceramic or sand-lime blocks, solid or hollow. The mortar is a mixture of sand, cement, lime and water responsible for laying and unifying the units. It transmits and uniforms the stresses throughout the blocks, seal out water and wind and even out small deformations. Rebars are steel bars surrounded by grout that make all components of the masonry work together. The grout is a very fluid micro concrete with aggregates and it is responsible for the union of blocks with rebars within its hollows.

The rationalization of structural masonry brings results by improving productivity and quality, with consequent increased value added. It also incentives increase in productivity and cost reduction in the supply chain, while meeting construction standards. As a result, the final consumer can buy at a lower price.

Modulation was already used by the Greeks, Romans and Japanese. It represented to them, respectively, aesthetic, functional and aesthetic and functional character. At present time, for the modulation process to be harmonized, it is needed to update the standard as to the sizing of the blocks. The incompatibility between the dimensions of the components of the building often results in large thicknesses dimensional settings and designs solutions that do not properly address these adjustments, which end up being performed impromptu in the work site.

The advantages of modulation are: simplification in project design, standardization of building components, optimization of the dimensions with reduction of different shapes, less interface problems between components and 
subsystems, standardization of detail and dimensional accuracy, rationalization and simplification in the execution of the work due to ease of assembly, reduction of material breaks, thus avoiding losses in construction. The disadvantages are: the need to have standardized components without dimensional and qualitative variation in the market, and need for investment in preparation and training of manpower.

The definition of the system to be used by the constructor occurs in the study phase. It is usually observed: the type and purpose of the project, the maximum number of floors, the ceiling heights between slabs, the size of compartments and wall allocation, the eventual need for sheltered parking and its mixed solution analysis, the size of balconies, the need for flexibility of plans, if penthouses should have swimming pool, the dimensioning of the common areas. In the cases where the product can fit in structural masonry guidelines, this has been the preferred construction system.

The project in structural masonry should consider the coordination between the various project disciplines with the integration between the design teams. Schedule of the project design should be prepared with the correct interaction of reconciliations. The design should be standardized and simplify the solutions and should provide full details of projects to avoid doubts and execution errors during construction.

Wall rebar can be done directly with interlocking blocks, requiring interposition between blocks of $50 \%$ in intercepted wall. It also can be done by placing the rebar in mortar joints with $90^{\circ}$ angle, as well as through folded steel bars, industrialized trusses or staples, steel decks or similar materials of proven resistance.

Electrical installation must be standardized in the predefined rows heights. The hydraulic and gas installations must be apparent and not embedded in order not to interfere in modulations. The project modulated masonry must have solutions that minimize the need for adjustments or additional elements while helping reconcile the different project disciplines.

This constructive method is examined regarding its execution details, increase in production and other benefits to the construction itself. 
Furthermore, qualitative impacts on the product and the social and cultural aspects due to the system's technical limitations and the applicable laws and regulations are analyzed.

The main certifications like AQUA, LEED, PROCEL EDIFICA, CASA AZUL, SANTANDER OBRA SUSTENTÁVEL and QUALIVERDE were analyzed in view of the current necessity of the real estate market to seek for more sustainable construction processes. It was analyzed the positive and negative aspects, as well as possible limitations of structural masonry for obtaining the building approvals.

Two recently launched projects in structural masonry were analyzed. Through case studies one can compare them to competing projects built in conventional reinforced concrete structure and it is possible to understand the main differences between the products.

The projects were also evaluated for the possibility of obtaining green building certification. AQUA was chosen as the reference certification. It provided the features used in the comparative between the different systems. To meet all categories of the certification, some aspects of the project might need to be adjusted, such as layout, wall thickness and span dimension.

The main conclusion is that structural masonry will not always completely fulfill the needs of various projects because of certain technical limitations. Taking sustainability into account, structural masonry has a number of benefits beginning with the modulation of the process which generates less waste. However, it can limit the design of more comfortable and sophisticated products, for example with differentiated solutions for layout and façades.

Even considering that some companies have used structural masonry in the construction of buildings for the middle class, with selling prices around BRL 7,000 to BRL 8,000 per square meter, this solution was not well accepted either by the contractors or those clients, whereas it is largely used in lower class constructions.

\section{Keywords}

Sustainability; civil construction; constructive technologies; structural masonry. 


\section{Sumário}

1. Introdução 20

$\begin{array}{ll}\text { 1.1. Justificativas } & 20\end{array}$

$\begin{array}{ll}\text { 1.2. Objetivos } & 21\end{array}$

$\begin{array}{ll}\text { 1.2.1. Objetivo geral } & 21\end{array}$

$\begin{array}{ll}\text { 1.2.2. Objetivos específicos } & 21\end{array}$

$\begin{array}{ll}\text { 1.3. Metodologia } & 21\end{array}$

1.4. Organização da dissertação 22

2. Mercado da construção civil na cidade do Rio de Janeiro 23

2.1. Histórico da construção civil na cidade do Rio de Janeiro 23

2.2. Sustentabilidade na indústria da construção civil 30

2.2.1. Cadeia produtiva da construção 31

2.2.2. Contexto atual da sustentabilidade na construção civil 33

2.3. Contexto atual da construção civil na cidade do

Rio de Janeiro e o incremento da alvenaria estrutural 36

3. Sistema construtivo em alvenaria estrutural 46

3.1. Histórico do sistema construtivo em alvenaria estrutural 46

3.1.1. Edificações históricas em alvenaria estrutural 47

3.1.2. Edificações em alvenaria estrutural no Brasil 50

3.2. Conceito do sistema $\quad 51$

3.3. Estudo dos materiais $\quad 52$

3.3.1. Componentes do sistema construtivo 52

3.3.1.1. Unidade 52 
$\begin{array}{ll}\text { 3.3.1.2. Argamassa } & 54\end{array}$

3.3.1.3. Armaduras 54

3.3.1.4. Graute 54

3.3.2. Materiais alternativos $\quad 55$

3.3.2.1. Bloco de concreto reforçado com fibras de polipropileno 55

3.3.2.2. Concreto leve 55

3.3.2.3. Concreto reciclado 56

3.4. Modulação $\quad 59$

3.4.1. Aspectos históricos da modulação 61

3.4.2. Modulação na alvenaria estrutural 63

3.4.3. Vantagens e desvantagens da coordenação modular 64

3.5. Projetos em alvenaria estrutural 65

3.5.1. Eficiência desde o projeto 70

3.6. Execução de obra em alvenaria estrutural e economias 74

4. Legislação

4.1. Limitações da legislação 82

4.1.1. NBR 15961: Alvenaria estrutural - blocos de concreto 82

4.1.1.1. NBR 15961-1: Parte 1 - Projeto 82

4.1.1.2. NBR 15961-2: Parte 2 - Execução e controle de obras 83

4.1.2. NBR 15270-2: Componentes cerâmicos - Parte 2 - Blocos
cerâmicos para alvenaria estrutural - Terminologia e requisitos

4.1.3. NBR 6136: Bloco vazado de concreto simples para alvenaria estrutural $\quad 85$

4.1.4. NBR 10837: Cálculo de alvenaria estrutural de blocos vazados de concreto 
4.1.5. NBR 8949: Paredes de alvenaria estrutural -

Ensaio a compressão simples

4.1.6. NBR 15873 - Coordenação modular para edificações

88

5. Certificações 89

5.1. Incentivos atuais com vistas à sustentabilidade 89

5.1.1. Selo AQUA - Alta Qualidade Ambiental 89

5.1.2. LEED - Leadership in Energy and Environmental Design 92

5.1.3. Selo Procel Edifica 95

5.1.4. Selo Casa Azul 96

5.1.5. Selo Santander 100

5.1.6. Selo Qualiverde 101

6. Estudo de caso 104

6.1. Empreendimento $1 \quad 104$

$\begin{array}{ll}\text { 6.2. Empreendimento } 2 & 107\end{array}$

6.3. Aspectos do sistema nos empreendimentos em questão 109

7. Conclusões e sugestões para trabalhos futuros 122

7.1. Conclusões 122

$\begin{array}{ll}\text { 7.2. Sugestões } & 123\end{array}$

8. Referências bibliográficas 125

9. Sítios consultados 


\section{Lista de figuras}

Figura 2.1 - Percentual de lançamentos por bairros - $2005 \quad 26$

Figura 2.2 - Percentual de lançamentos por bairros - $2006 \quad 26$

Figura 2.3 - Percentual de lançamentos por bairros - $2007 \quad 27$

Figura 2.4 - Percentual de lançamentos por bairros - $2008 \quad 27$

Figura 2.5 - Percentual de lançamentos por bairros - $2009 \quad 28$

Figura 2.6 - Percentual de lançamentos por bairros - $2010 \quad 28$

Figura 2.7 - Percentual de lançamentos por bairros - $2011 \quad 29$

Figura 2.8 - Percentual de lançamentos por bairros - 2012

Figura 2.9 - Elos da produção na cadeia da construção 32

Figura 2.10 - Linha do tempo da sustentabilidade 34

Figura 2.11 - Principais empreendimentos lançados entre 2008 e 2012 por padrão

Figura 2.12 - Principais empreendimentos lançados entre 2008 e 2012 por bairro/região

Figura 2.13 - Principais empreendimentos lançados entre 2008 e 2012 por sistema construtivo

Figura 2.14 - Total aproximado de área construída referente aos lançamentos em alvenaria estrutural entre 2008 e 2012

Figura 2.15 - Custo aproximado do total de área construída referente aos lançamentos em alvenaria estrutural entre 2008 e 2012 e economia em relação ao sistema de estrutura convencional em concreto armado

Figura 3.1 - Pirâmides de Guizé $\quad 47$

Figura 3.2 - Coliseo $\quad 48$

Figura 3.3 - Catedral de Reims 48

Figura 3.4 - Edifício Monadnock $\quad 49$

Figura 3.5 - Hotel Excalibur $\quad 50$

Figura 3.6 - Exemplo de blocos cerâmicos 53

Figura 3.7 - Exemplo de blocos de concreto $\quad 54$

Figura 3.8 - Exemplo de equipamento para a reciclagem de entulhos e resíduos da construção civil $\quad 57$

Figura 3.9 - Exemplo de tapume de obras com coleta seletiva 58

Figura 3.10 - Ciclo dos resíduos da construção civil sem reciclagem $\quad 58$

Figura 3.11 - Ciclo dos resíduos da construção civil com reciclagem $\quad 59$

Figura 3.12 - Vãos normais e de esquina na arquitetura grega 61 
Figura 3.13 - Planta de residência típica japonesa

Figura 3.14 - Planta de arquitetura

Figura 3.15 - Planta de modulação M-15 da $1^{\mathrm{a}}$ fiada com blocos BL-15 66

Figura 3.16 - Planta de modulação $\mathrm{M}-15$ da $1^{\mathrm{a}}$ fiada com blocos BL-15 e emprego de bloco especial de $35 \mathrm{~cm}$ de comprimento modular

Figura 3.17 - Exemplo de amarração direta 69

Figura 3.18 - Exemplo de amarração indireta 69

Figura 3.19 - Exemplo de planta e legenda de projeto de alvenaria com modulação da $2^{\mathrm{a}}$ fiada $\quad 72$

Figura 3.20 - Exemplo de vista de projeto de alvenaria modulada $\quad 74$

Figura 3.21 - Assentamento primeira fiada $\quad 75$

Figura 3.22 - Encaixe dos blocos nas barras de aço $\quad 75$

Figura 3.23 - Verificação do alinhamento entre os blocos da mesma fiada 76

Figura 3.24 - Preparação blocos com pontos de instalação 76

Figura 3.25 - Utilização de ferramentas corretas para aplicação de argamassa $\quad 77$

Figura 3.26 - Marcação das extremidades da alvenaria $\quad 77$

Figura 3.27 - Verificação do alinhamento, nível e prumo da alvenaria 78

Figura 3.28 - Passagem das tubulações elétricas e hidráulicas na alvenaria

Figura 3.29 - Nível e prumo das paredes $\quad 79$

Figura 3.30 - Intersecção perpendicular entre as paredes 79

Figura 3.31 - Execução de vãos: janelas e portas 80

Figura 3.32 - Reforço vertical nas extremidades $\quad 80$

Figura 3.33 - Execução da cinta $\quad 81$

Figura 5.1 - Logomarca Processo AQUA - Construção Sustentável 89

Figura 5.2 - Logomarca LEED - Leadership in Energy and Environmental Design $\quad 92$

Figura 5.3 - Logomarca Procel Edifica 95

Figura 5.4 - Logomarca Selo Casa Azul - Construção sustentável 96

Figura 5.5 - Logomarca Selo Santander - Obra sustentável $\quad 100$

Figura 5.6 - Logomarca Prefeitura do Rio de Janeiro 102

Figura 6.1 - Localização do empreendimento 1 
Figura 6.2 - Perspectiva ilustrativa da fachada do empreendimento $1 \quad 105$

Figura 6.3 - Masterplan do empreendimento $1 \quad 106$

Figura 6.4 - Planta da unidade de 3 quartos do empreendimento 1

Figura 6.5 - Localização do empreendimento $2 \quad 107$

Figura 6.6 - Perspectiva ilustrativa do empreendimento $2 \quad 108$

Figura 6.7 - Masterplan do empreendimento 2

Figura 6.8 - Planta da unidade de 3 quartos do empreendimento $2 \quad 109$

Figura 6.9 - Varanda embutida: empreendimento Minha Praia $\quad 110$

Figura 6.10 - Varanda do empreendimento Onda Carioca 110

Figura 6.11 - Opção de ampliação da sala na planta da unidade de três quartos do empreendimento 1

Figura 6.12 - Opção de ampliação da sala no empreendimento Park Premium

Figura 6.13 - Exemplo de planta de cobertura (pavimento inferior) do empreendimento 1

Figura 6.14 - Exemplo de planta de cobertura (pavimento superior) do empreendimento 1

Figura 6.15 - Exemplo de planta de cobertura do empreendimento Park Premium

Figura 6.16 - Exemplo de planta de cobertura do empreendimento Onda Carioca

Figura 6.17 - Planta pavimento térreo de um dos blocos do empreendimento 1

Figura 6.18 - Perspectiva ilustrativa da academia do empreendimento 1

Figura 6.19 - Perspectiva ilustrativa da academia do empreendimento 2

Figura 6.20 - Perspectiva ilustrativa do salão de festas do empreendimento 2

Figura 6.21 - Perspectiva ilustrativa da brinquedoteca do empreendimento Onda Carioca

Figura 6.22 - Perspectiva ilustrativa da academia do empreendimento Park Premium 


\section{Lista de tabelas}

Tabela 2.1 - Principais empreendimentos residenciais lançados em 2008

Tabela 2.2 - Principais empreendimentos residenciais lançados em 2009

Tabela 2.3 - Principais empreendimentos residenciais lançados em 2010

Tabela 2.4 - Principais empreendimentos residenciais lançados em 2011

Tabela 2.5 - Principais empreendimentos residenciais lançados em 2012

Tabela 3.1 - Medidas modulares romanas

Tabela 3.2 - Dimensões reais dos blocos modulares e submodulares de concreto segundo a NBR 6136

Tabela 3.3 - Dimensões reais dos blocos cerâmicos segundo a NBR 7171

Tabela 6.1 - Análise da redução de emissão de CO2 nos empreendimentos de estudo

Tabela 6.2 - Análise certificação AQUA nos empreendimentos de estudo 


\section{Ofício}

Os poemas que não fiz não os fiz porque estava dando ao meu corpo aquela espécie de alma que não pôde a poesia nunca dar-lhe Os poemas que fiz só os fiz porque estava pedindo ao corpo aquela espécie de alma que somente a poesia pode dar-lhe Assim devolve o corpo a poesia que se confunde com o duro sopro de quem está vivo e às vezes não respira.

Gastão Cruz 


\section{1 \\ Introdução}

1.1

Justificativas

Atualmente existe uma tendência do mercado da construção civil, espelhada na tendência mundial, para a busca de práticas sustentáveis em seus processos.

O desenvolvimento sustentável tem como objetivo utilizar os recursos naturais de forma racional, para que os mesmos não se esgotem no futuro.

Com a crescente evolução e importância do mercado da construção civil, fez-se necessária a substituição de práticas e métodos ultrapassados em prol de técnicas que minimizassem os impactos ambientais, garantindo o equilíbrio entre as três vertentes do desenvolvimento sustentável: econômica, social e ambiental.

Um dos processos na construção civil que minimizam os impactos ao meio ambiente é o método construtivo em Alvenaria Estrutural.

O principal objetivo desse método é aumentar a racionalização construtiva elevando a produtividade e reduzindo desperdícios e custos.

Em uma obra de Alvenaria Estrutural a execução normalmente é mais rápida em função do apuro no detalhamento do projeto, melhor padronização na execução dos procedimentos construtivos e maior simplicidade inerente ao processo. Além disso, existe a possibilidade de organização da produção para que o processo tenha um grau elevado de industrialização. A coordenação pode ser realizada de forma modular e é possível se obter um rígido controle de qualidade. Considerando o pós uso, o empreendimento irá gerar menos resíduos de obra, uma vez que as paredes não podem ser removidas e que normalmente as instalações hidráulicas não são embutidas podendo ser visitadas por shafts e carenagens. 


\section{2}

\section{Objetivos}

\subsection{1}

Objetivo Geral

Como objetivo geral, esta dissertação avalia a viabilidade de utilização do sistema construtivo em alvenaria estrutural como uma solução sustentável para empreendimentos imobiliários na cidade do Rio de Janeiro e avalia ainda a coerência do sistema construtivo com as diretrizes pré-estabelecidas por legislações e certificações inerentes ao tema.

Também constata as principais benefícios e os pontos de maior deficiência quando da escolha do sistema, tanto para as incorporadoras como para o cliente final.

\subsection{2 \\ Objetivos Específicos}

A seguir são listados os objetivos específicos desta dissertação.

1) Investigar e mapear na cidade do Rio de Janeiro o crescimento dessa técnica como solução construtiva para os empreendimentos.

2) Organizar as informações sobre especificidade dos projetos, materiais, tecnologia e forma de execução do processo que fazem com que a solução construtiva seja considerada sustentável, além de contribuir para a perpetuidade do meio ambiente, e proporcionar em longo prazo ganhos financeiros para o cliente final.

\section{3}

\section{Metodologia}

O tema será estudado por meio de pesquisa exploratória, utilizando-se o método estudo de caso.

Serão analisados os principais empreendimentos lançados nos últimos anos na cidade do Rio de Janeiro pelas empresas mais atuantes do mercado da construção civil. 


\section{4 \\ Organização da dissertação}

Essa dissertação foi dividida em sete capítulos. O primeiro capítulo apresenta uma breve introdução sobre as tendências atuais do mercado da construção civil na busca por processos sustentáveis, dentre eles, a alvenaria estrutural, e destaca os principais objetivos do trabalho.

O capítulo dois aborda o histórico do mercado da construção civil no Rio de Janeiro e sua evolução durante os últimos anos. Também traz informações sobre o desenvolvimento do tema sustentabilidade neste mercado bem como o contexto atual na cidade do Rio de Janeiro e o incremento da alvenaria estrutural.

$\mathrm{O}$ capítulo três discorre sobre o histórico do sistema construtivo em alvenaria estrutural desde as primeiras e notáveis edificações do mundo até os edifícios construídos no Brasil. É também neste capítulo que o sistema é conceituado com informações sobre materiais, modulação, projetos e execução das obras.

O capítulo quatro informa as principais legislações relacionadas à alvenaria estrutural que determinam os critérios para a elaboração dos projetos e execução das obras.

O capítulo cinco aborda as principais certificações em sustentabilidade direcionadas as edificações habitacionais. Demonstra ainda os incentivos atuais e relaciona os principais critérios de pontuação que um empreendimento em alvenaria estrutural pode obter ou não.

O capítulo seis descreve dois empreendimentos em alvenaria estrutural selecionados para o estudo de caso identificando os pontos positivos e negativos relacionados ao sistema em relação ao padrão do mesmo. Neste capítulo também há uma análise sobre a possibilidade de certificação AQUA para esses dois empreendimentos.

O capítulo sete resume as principais conclusões do trabalho e apresenta algumas sugestões para pesquisas futuras. 


\section{2 \\ Mercado da construção civil na cidade do Rio de Janeiro}

\section{1}

\section{Histórico da construção civil na cidade do Rio de Janeiro}

Os primeiros registros de construção civil no Brasil têm sua origem no período colonial. Eram atividades não regulamentadas como construções de fortificações e igrejas (MORAES, 2005).

Nesse período as categorias de profissionais que atuavam na área de engenharia eram os oficiais engenheiros e os mestres pedreiros. Os primeiros eram oficiais do exército português, cujo objetivo principal era a execução de obras de engenharia. Alguns não tinham curso regular na área, mas eram os únicos que tinham algum conhecimento sistemático a respeito. Os mestres, também chamados mestres de risco, projetavam e construíam as edificações em geral, e seus conhecimentos eram passados de geração a geração, sem nenhum conhecimento científico (TELLES, 1984).

Em 1810 foi criada por D. João VI a escola de engenharia brasileira, a Academia Real Militar do Rio de Janeiro. Nessa época quem executava tais serviços era chamado de engenheiro militar (mesmo não exercendo a carreira militar). Posteriormente, a academia teve seu nome mudado para Escola Politécnica do Rio de Janeiro e em 1858 foi criado o curso de engenharia civil ministrado aos civis (UFRJ, 2007).

No final do século XIX e início do século XX as cidades do país, principalmente as do sudeste, passaram por um momento de intensa transformação em função do momento econômico, com o auge e a decadência da cultura do café e o posterior desenvolvimento industrial.

Efetivamente 1930 é o ano que marca o início da industrialização no Brasil. Foi nesse ano que a atividade industrial passou a ser a mais importante do país. Esse início foi favorecido pela Crise de 1929, quando os Estados Unidos, principal comprador de café do Brasil, reduziu a compra desse produto ocasionando a transferência da capital da cafeicultura em decadência para a indústria. Após a Revolução de 1930, com a derrubada do governo oligárquico e 
com o início da chamada Era Vargas, Getúlio Vargas assumiu o poder e defendeu, dentre outros itens, o desenvolvimento da indústria nacional.

$\mathrm{Na}$ década de 1940 a construção civil teve um grande desenvolvimento. O setor foi considerado uns dos mais avançados da época. O Brasil era detentor importante da tecnologia do concreto armado.

"Em 1971, o setor da construção deu uma deslanchada muito grande na cidade do Rio de Janeiro. A criação do BNH, em 1967, e a Lei 4591 das Incorporações haviam facilitado imensamente a obtenção de financiamento. $O$ que se via era um fantástico boom imobiliário: os imóveis lançados eram vendidos e havia até ágio para a sua recompra. Era um momento excepcional para o Rio, que passou por profundas modificações, como a construção do Túnel Rebouças e do Aterro do Flamengo. Ipanema, Leblon e Lagoa ainda eram vistos como bairros de veraneio" (José Conde Caldas - ADEMI RJ: http://www.ademi.org.br, visitado em: 16/06/2012).

Na década de 1990 as construtoras começam a qualificar a mão de obra investindo em treinamentos e oferecendo produtos de qualidade elevada e mais personalizados.

Em 2000 as grandes construtoras buscaram ampliar seus landbanks com a aquisição de terrenos. Houve um boom imobiliário na zona oeste, mais especificamente no bairro da Barra da Tijuca que atualmente já quase não possui mais terrenos disponíveis. Em seguida, os investimentos giraram em torno do Recreio dos Bandeirantes e em Jacarepaguá.

"A Barra da Tijuca, o Recreio dos Bandeirantes e Jacarepaguá concentraram, em 2004, 71\% dos lançamentos. Já em 2005 esses três bairros reuniram 69\% de tudo que foi lançado na cidade e, em 2006, esse percentual foi de 76\%" (site ADEMI RJ: http://www.ademi.org.br, visitado em: 16/06/2012).

A partir de 2006 a zona norte, mesmo sendo uma área já consolidada e com pouca oferta de terrenos viáveis a implantação de empreendimentos, também foi alvo de grandes intervenções.

O lançamento de 989 unidades em um único empreendimento no Méier, elevou a participação deste bairro para 14\% do mercado em 2006 levando os investimentos para o crescimento da cidade também nessa direção. 
"Em 2007 essa tendência se comprova com bairros como Del Castilho e Campo Grande, que há muitos anos não recebiam novas unidades. Estes bairros atingiram, respectivamente, $7 \%$ e $6 \%$ do total de lançamentos do ano. Em 2008, além de termos Campo Grande em terceiro lugar (com $10 \%$ do mercado) e Campinho em sexto, bairros que não recebiam lançamentos imobiliários há anos como Pavuna e Abolição entraram no foco dos incorporadores"” (ADEMI RJ: http://www.ademi.org.br, visitado em: 16/06/2012).

Em setembro de 2008 o mercado foi surpreendido pela crise mundial que acabou por contribuir com o mau desempenho do primeiro semestre de 2009. No entanto, o programa Minha Casa Minha Vida do governo federal, ajudou a impulsionar uma virada surpreendente no segundo semestre deste ano, com resultados acima dos alcançados em 2008 que superaram todas as previsões.

Nos anos seguintes, o mercado continuou a crescer, buscando lançamentos pontuais no centro da cidade e na zona sul. Porém o novo eixo de crescimento está em direção aos bairros do Recreio dos Bandeirantes e Vargens fundamentado na aprovação de novos decretos de incentivo à construção nessas áreas e na própria valorização com investimentos em infraestrutura na região.

"Em 2010, em números absolutos, foram lançadas 19.994 unidades e em 2011, 25.197.

O crescimento do número de lançamentos do mercado imobiliário no ano de 2011 seguiu o excelente desempenho que vinha sendo desenhado desde 2010 e superou as 25 mil unidades que eram esperadas." (ADEMI RJ: http://www.ademi.org.br, visitado em: 10/01/2013).

As Figuras 2.1 a 2.8 mostram os percentuais de lançamentos imobiliários entre os anos de 2005 e 2012 separados por bairros da cidade do Rio de Janeiro. 


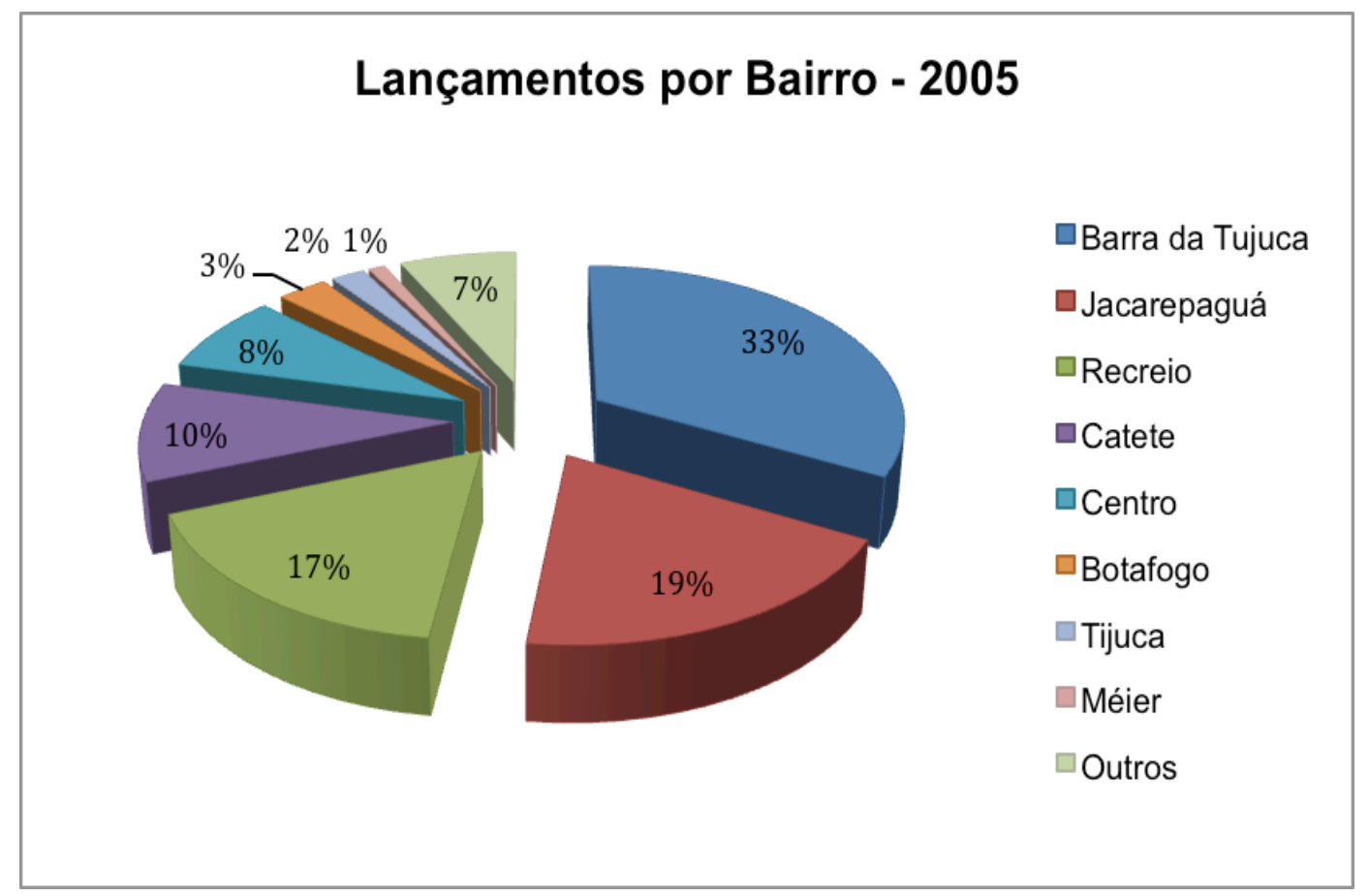

Figura 2.1 - Percentual de lançamentos por bairros - 2005; ADEMI RJ: http://www.ademi.org.br, visitado em: 16/06/2012.

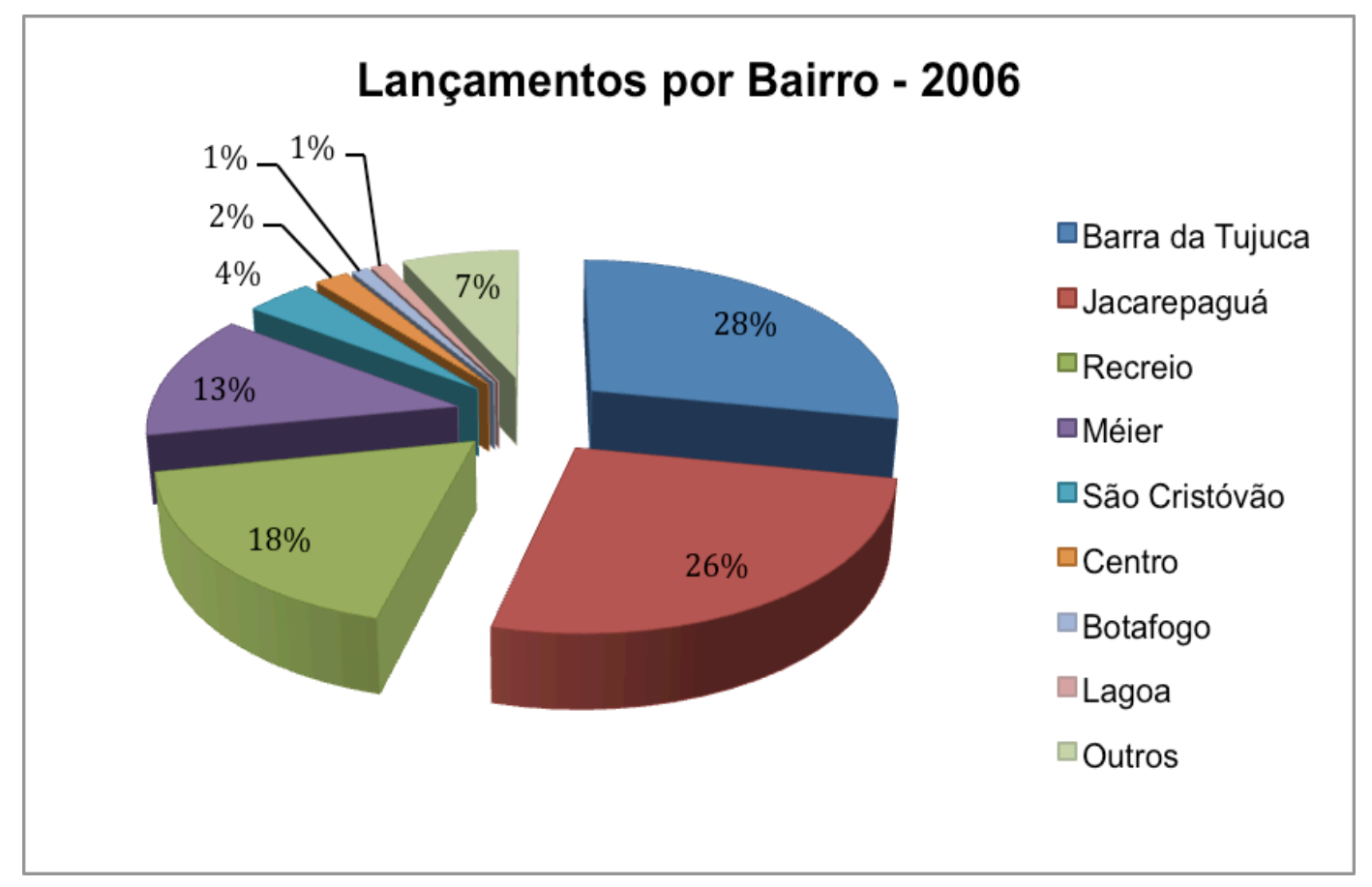

Figura 2.2 - Percentual de lançamentos por bairros - 2006; ADEMI RJ: http://www.ademi.org.br, visitado em: 16/06/2012. 


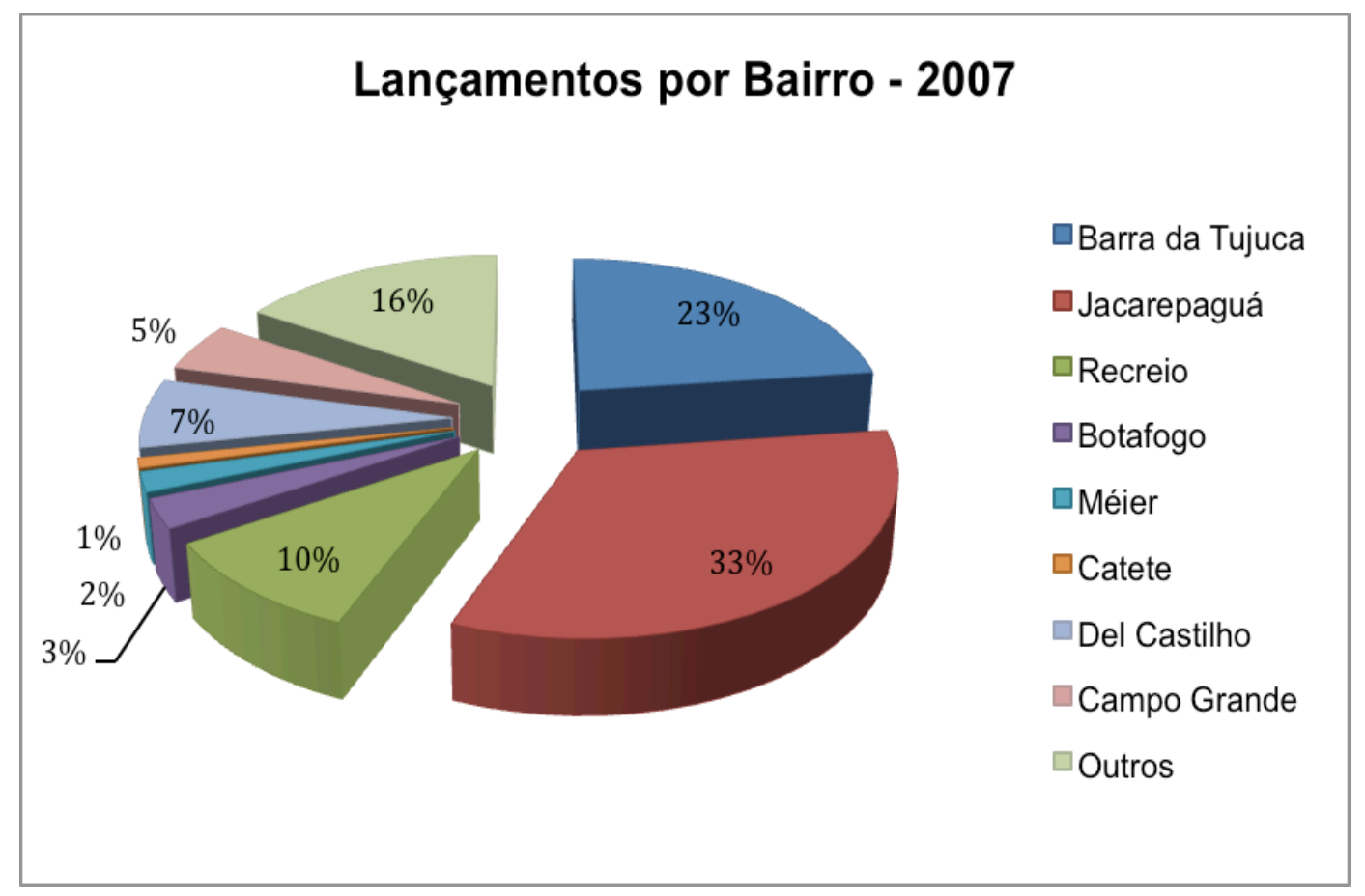

Figura 2.3 - Percentual de lançamentos por bairros - 2007; ADEMI RJ:

http://www.ademi.org.br, visitado em: 16/06/2012.

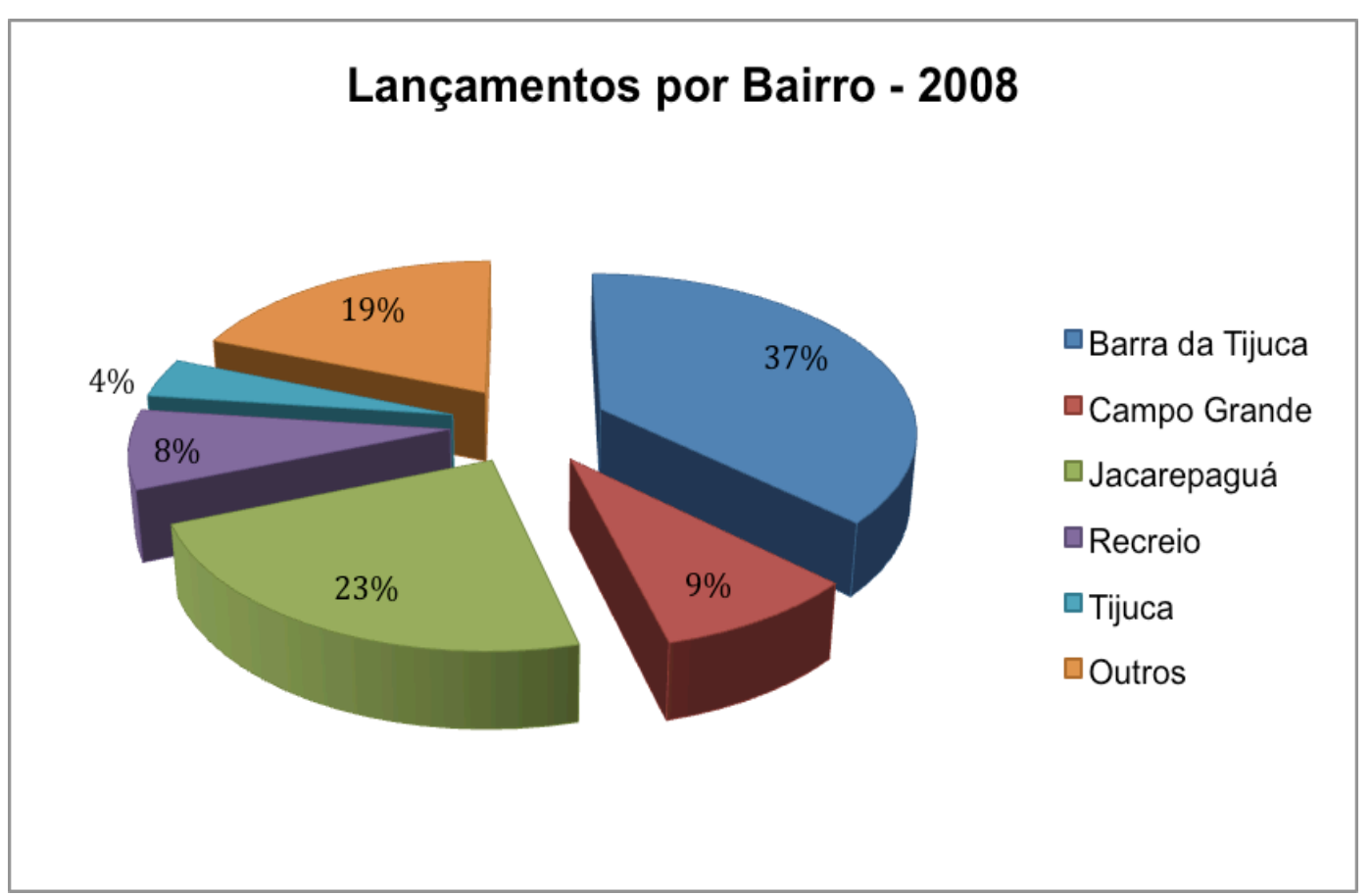

Figura 2.4 - Percentual de lançamentos por bairros - 2008; ADEMI RJ:

http://www.ademi.org.br, visitado em: 10/01/2013. 


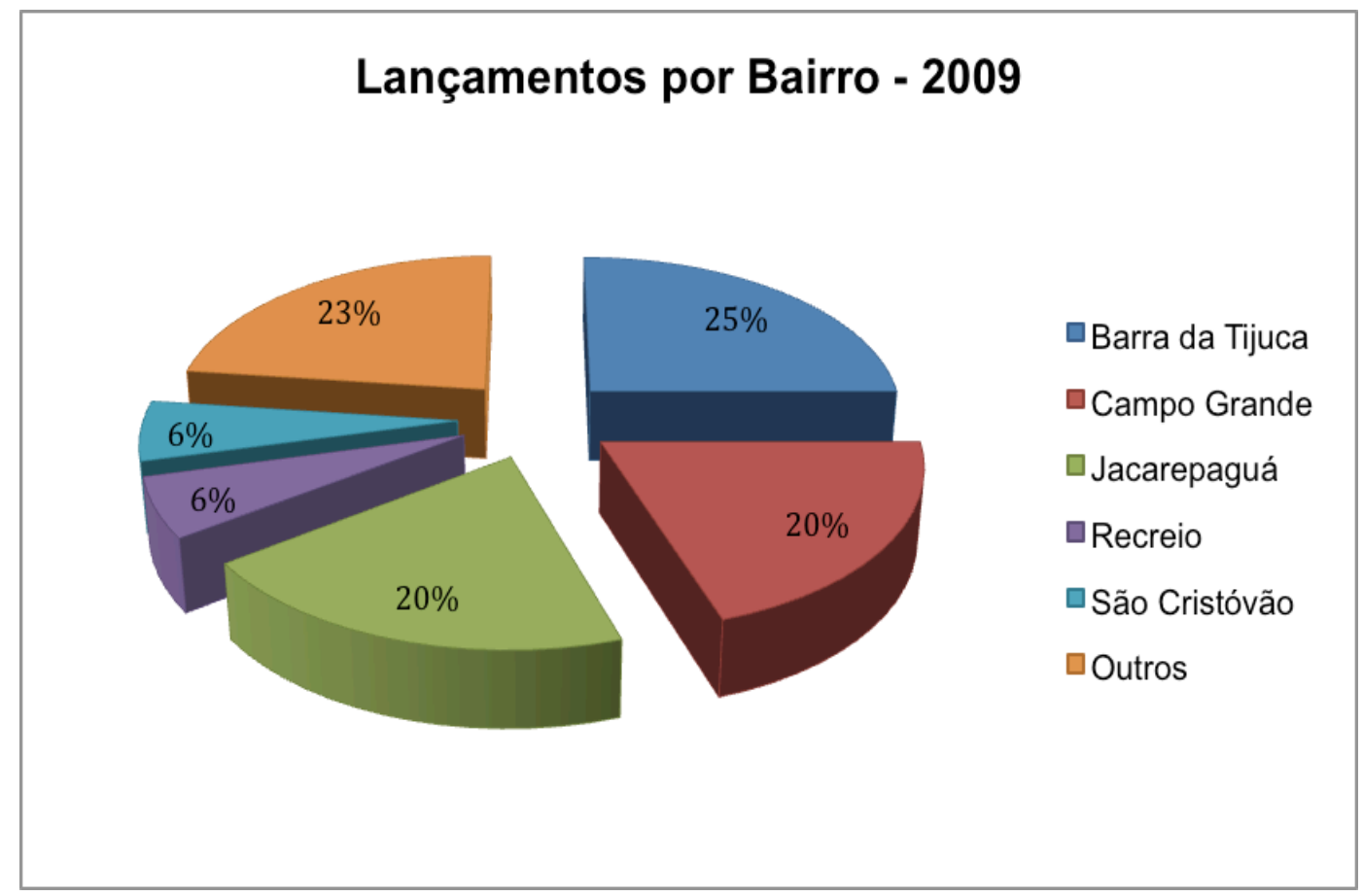

Figura 2.5 - Percentual de lançamentos por bairros - 2009; ADEMI RJ:

http://www.ademi.org.br, visitado em: 10/01/2013.

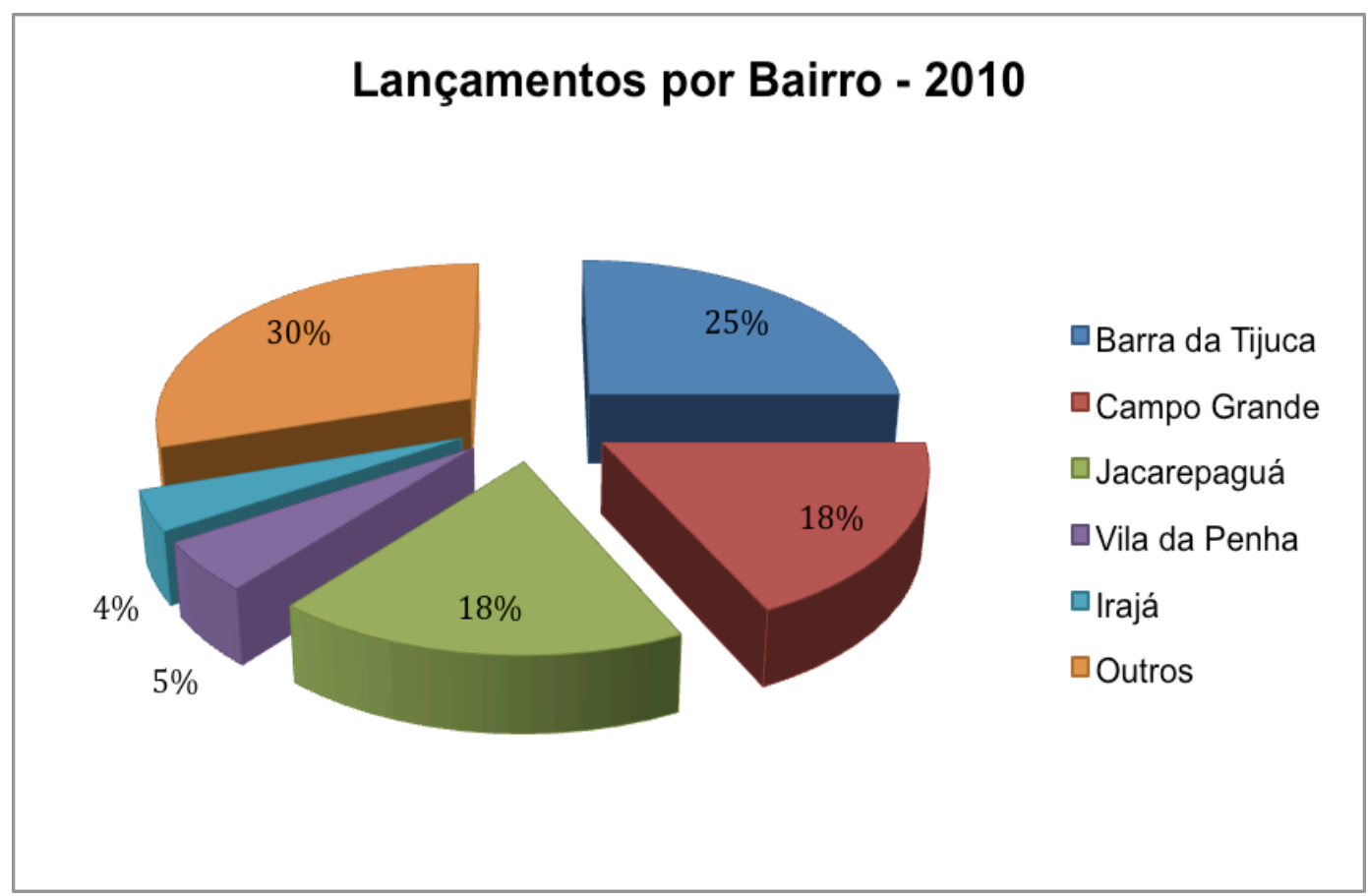

Figura 2.6 - Percentual de lançamentos por bairros - 2010; ADEMI RJ:

http://www.ademi.org.br, visitado em: 10/01/2013. 


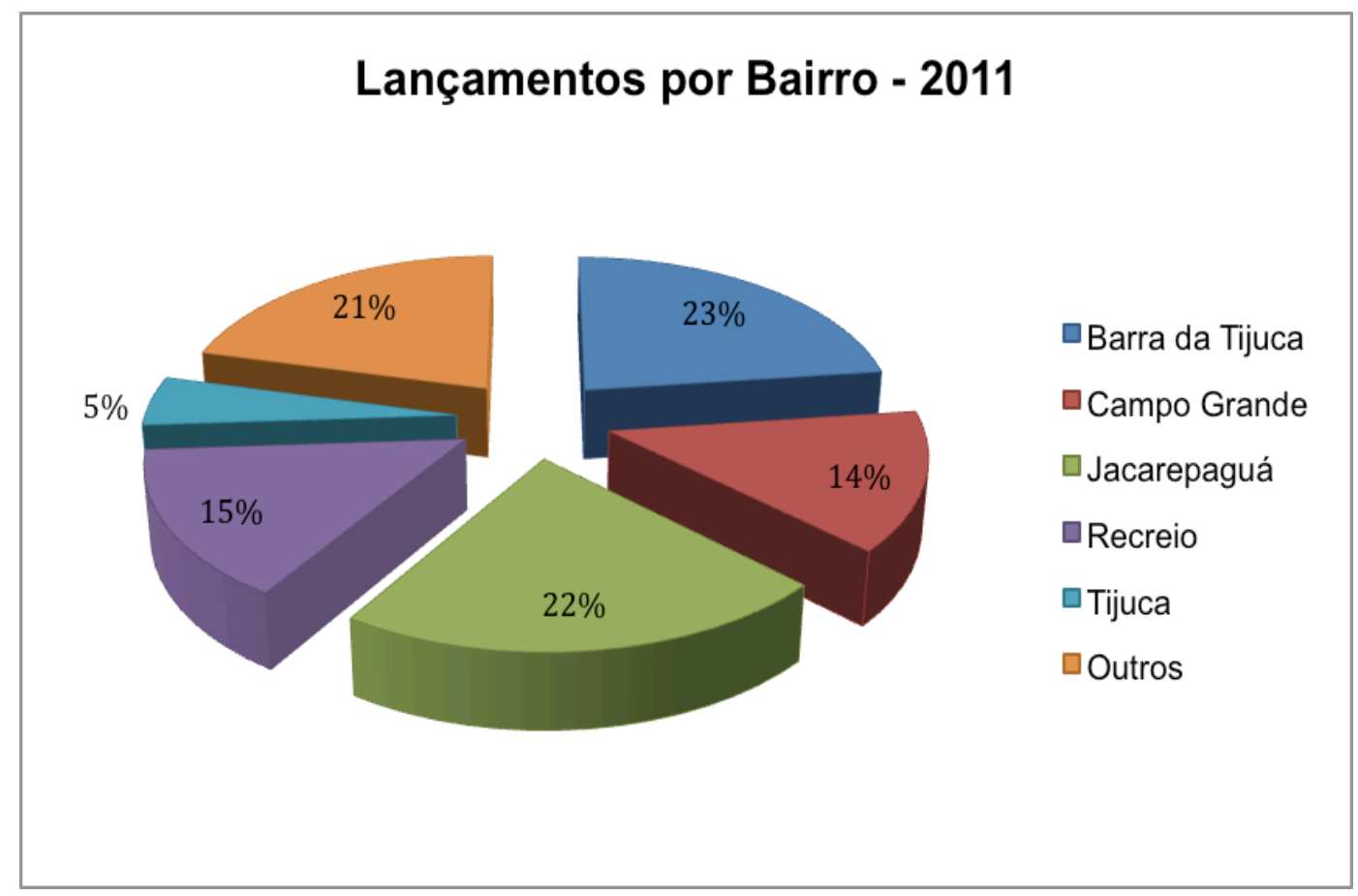

Figura 2.7 - Percentual de lançamentos por bairros - 2011; ADEMI RJ:

http://www.ademi.org.br, visitado em: 10/01/2013.

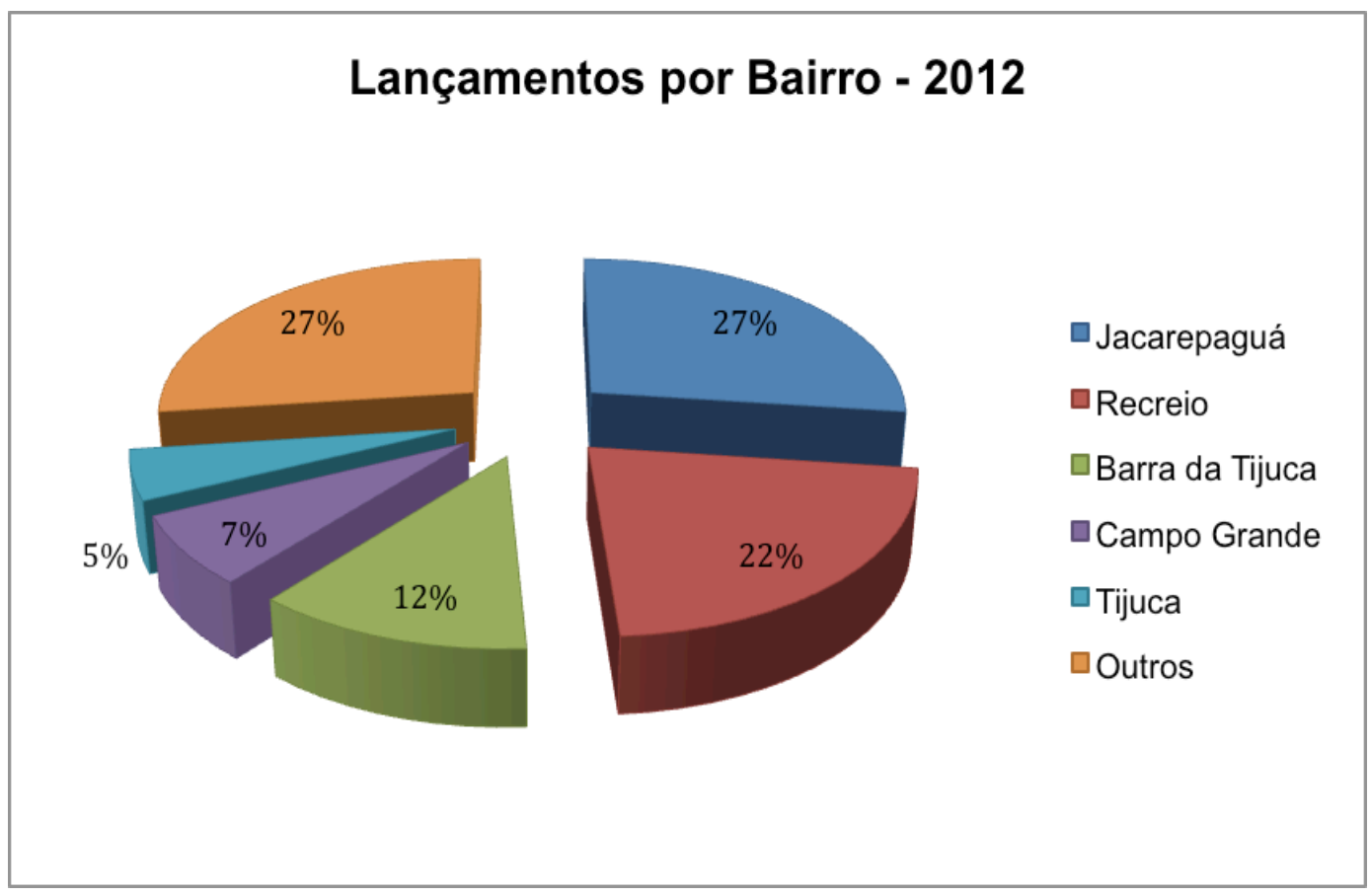

Figura 2.8 - Percentual de lançamentos por bairros - 2012; ADEMI RJ:

http://www.ademi.org.br, visitado em: 23/06/2013. 


\section{2}

\section{Sustentabilidade na indústria da construção civil}

O crescimento vertiginoso e inédito do mercado da construção civil fez com que o mesmo se tornasse recordista em número de empregos gerados, líder em concentração de investimentos e responsável pela mobilização de uma ampla cadeia produtiva. Esses fatores contribuíram para a estabilidade econômica do país durante a primeira fase da crise mundial de 2008.

Com todo esse crescimento surgiu também a necessidade e a preocupação em se ter um desenvolvimento sustentável. As construtoras passaram a investir em programas de redução de entulho, coleta seletiva e reciclagem de resíduos, estudos de redução das emissões de $\mathrm{CO} 2$, programas sociais e educacionais para a mão de obra que ficou bastante escassa com o grande crescimento do montante de obras, e programas sociais para a comunidade como um todo.

Essa mentalidade está cada vez mais presente no cotidiano dessas empresas, que incluem em seus processos e planos de metas tecnologias e premissas sustentáveis.

"Neste contexto, já somos o quarto país do mundo em número de empreendimentos com certificados de sustentabilidade e estamos promovendo uma verdadeira revolução nos canteiros de obra com geração de empregos em níveis cada vez maiores de qualificação que estão mudando para sempre o perfil de nossos profissionais. O setor tem dado provas do seu amadurecimento incorporando no dia a dia das empresas uma preocupação cada vez mais presente com o desenvolvimento e a inclusão social aliada ao cuidado ambiental." (Guia CBIC de boas práticas em sustentabilidade na indústria da construção, 2012).

Apesar da grande evolução do tema, muitas empresas da cadeia produtiva da construção ainda têm o desafio de lidar com a sustentabilidade e buscar soluções para problemas sociais e ambientais gerados por suas atividades.

Boa parte dessas empresas são de pequeno a médio porte e ainda não perceberam os benefícios e o retorno a médio e longo prazo que as novas medidas podem trazer aos seus processos e produtos.

As construtoras possuem o papel principal de exigir produtos e serviços condizentes com essa nova realidade incentivando a transformação em toda a cadeia. 


\subsection{1}

\section{Cadeia produtiva da construção}

Os impactos no setor da construção são variados, difusos e de longo prazo o que faz com que seja difícil mensurar os resultados. Eles têm início antes mesmo da produção de qualquer material empregado na execução das obras e só finalizam ao fim da vida útil do empreendimento a ser entregue.

Entende-se por vida útil do empreendimento o período de tempo em que o edifício e seus sistemas se prestam às atividades para as quais foram projetados e construídos, considerando a correta execução e periodicidade dos processos de manutenção especificados.

A cadeia produtiva da construção engloba além das construtoras e incorporadoras, prestadoras de serviços auxiliares para o planejamento e a realização das obras (serviços técnico-profissionais, financeiros e seguros), vários segmentos da indústria que produzem os materiais de construção e por segmentos do comércio varejista e atacadista.

A Figura 2.9 mostra os elos da produção através de uma planta da cadeia da construção. 


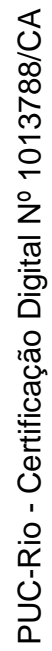

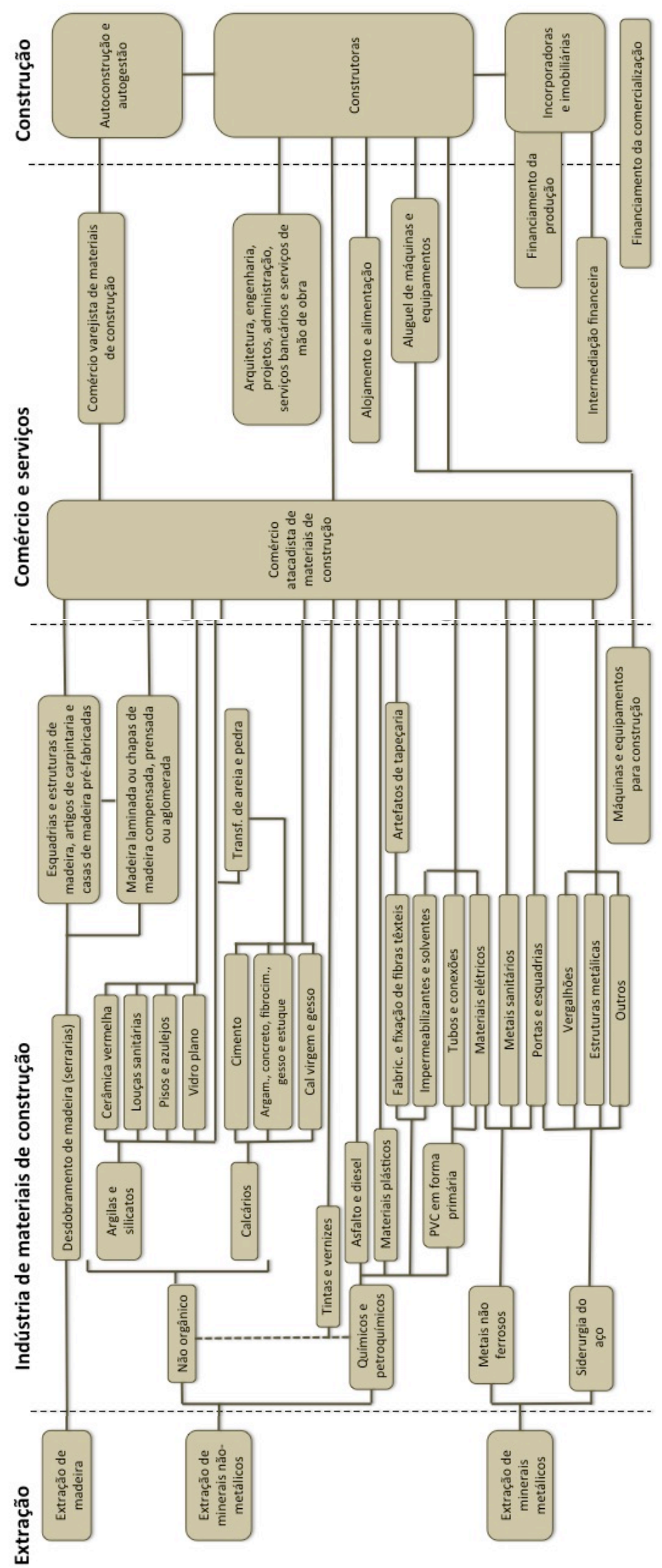

Figura 2.9 - Elos da produção na cadeia da construção; Guia CBIC de boas práticas em sustentabilidade na indústria da construção, 2012, pg 20 e 21. 


\subsection{2 \\ Contexto atual da sustentabilidade na construção civil}

Na década de 1960 foram constatados fenômenos naturais inéditos como chuvas ácidas e alta mortalidade de animais em áreas de lavoura.

A partir disso, cresceu o engajamento com relação ao cuidado com as questões ambientais e com o rumo que o planeta estava tomando.

Cresceram grupos de defesa à preservação ambiental e a eles se uniram interessados em direitos humanos entre outras questões sociais relevantes.

"Da pressão destes grupos de defesa à preservação ambiental e de ações no âmbito da Organização das Nações Unidas, em 1987, o termo Desenvolvimento Sustentável aparece pela primeira vez na forma de conceito: Aquele que atende as necessidades do presente sem comprometer a possibilidade de as gerações futuras atenderem as suas próprias necessidades. (COMISSÃO MUNDIAL SOBRE O MEIO AMBIENTE E DESENVOLVIMENTO, 1991)." (Guia CBIC de boas práticas em sustentabilidade na indústria da construção, 2012).

Alinhadas com esse discurso, as empresas começam a inovar com o objetivo comum de minimizar os impactos negativos gerados e passam a contribuir com uma sociedade justa, inclusive com as gerações futuras, produzindo impactos menores do que a capacidade do ambiente em se recuperar, garantindo a preservação da oferta de bens e serviços naturais para atingir o estágio da sustentabilidade.

A Figura 2.10 mostra a linha do tempo da sustentabilidade com a indicação de fatos importantes ocorridos durante os anos. 


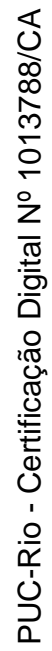
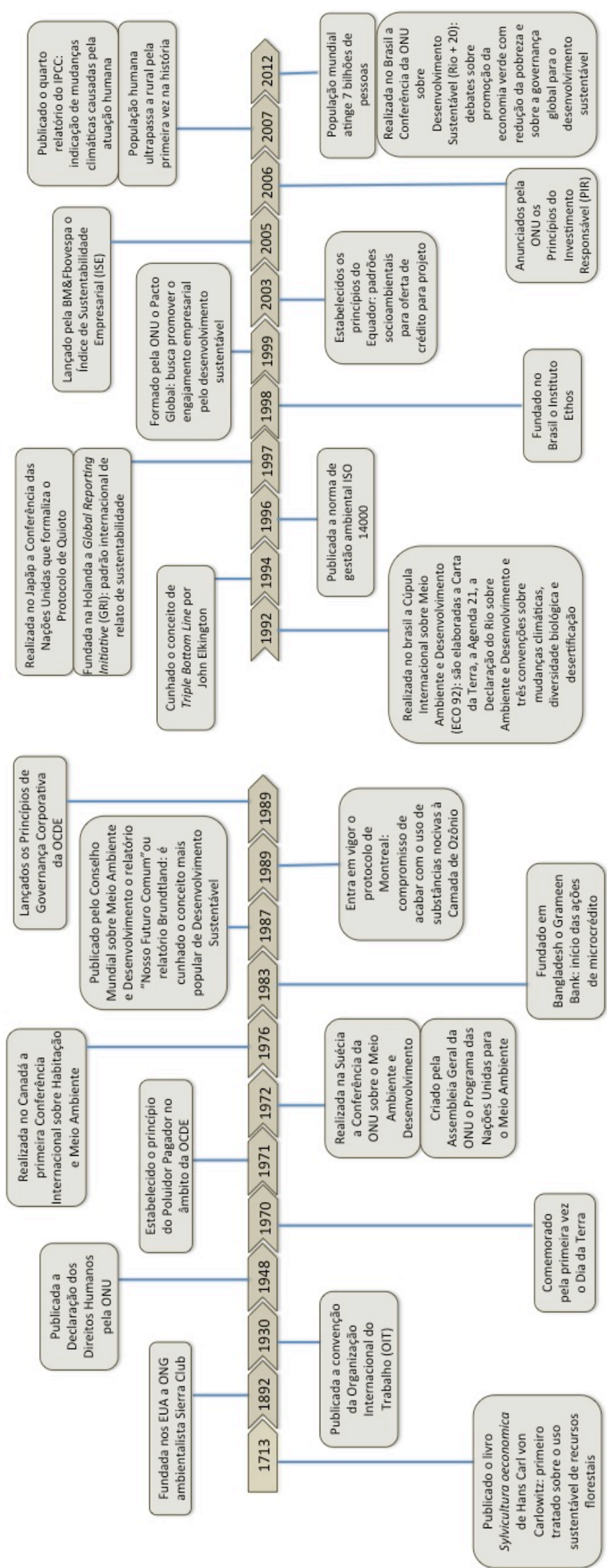

Figura 2.10 - Linha do tempo da sustentabilidade; Guia CBIC de boas práticas em sustentabilidade na indústria da construção, 2012, p. 22 e 23. 
De acordo com (PNUD, 2012) a construção é responsável por 12\% do consumo total de água. A cadeia tem emissões de gases de efeito estufa significativos. As atividades de construção geram $40 \%$ de todos os resíduos gerados pela sociedade e grandes empreendimentos de infraestrutura geram pressão sobre diferentes ecossistemas.

O mercado da construção tem grande impacto econômico para o país.

Segundo estudos da ABRAMANT e FGV (2011), a cadeia produtiva teve uma produção total de aproximadamente $\mathrm{R} \$ 300$ bilhões em 2010, o que equivale a $8,1 \%$ do PIB brasileiro.

A indústria da construção certamente será importante para o futuro crescimento do país em função da grande demanda por obras habitacionais e de infraestrutura.

Atualmente tem-se notado uma grande pressão sobre as empresas para atuarem de acordo com os princípios de sustentabilidade.

O governo vem apresentando papel importante, nas esferas federal, estadual e municipal para a regulação do setor. Uma importante medida foi a regulamentação da seleção de resíduos com a resolução 307 do Conama, que definiu cinco classes para categorizar os resíduos da construção. Também em 2010 foi sancionada a Lei número 12.305 que instituiu a política nacional de resíduos sólidos.

Além disso, o estímulo à produção de unidades habitacionais de baixa renda pelo governo vem impulsionando o setor. Para participar dos programas são impostos condicionantes por meio de legislação ou por imposição de empresas públicas.

Pontualmente, crescem as regras locais para o setor da Construção, como por exemplo, a imposição de medições individualizadas de água e gás, aquecimento solar de água e elaboração de programas de gestão de resíduos.

Já existem normas técnicas que indicam como as empresas podem construir um sistema de gestão integrada, como por exemplo:

a) NBR ISO 9000 para a qualidade;

b) NBR ISO 14000 para o meio ambiente;

c) OSHAS 18000 e SA 8000 para a saúde e segurança do trabalhador;

d) NBR 16000, NBR ISO 26000 para a gestão da responsabilidade social. 
Existe ainda a Norma de Desempenho (NBR 15575) que indica o desempenho mínimo exigido dos sistemas estruturais, de pisos, de vedações, de coberturas e hidrossanitários das novas edificações residenciais.

Também estão sendo responsáveis pelo processo de adesão às práticas sustentáveis as diversas certificações ambientais: LEED, do Green Building Council Brasil; AQUA, da Fundação Vanzolini; o BREEAM, da BRE e o DNGB do Conselho Alemão de Construção Sustentável.

Já no setor público contamos com a Etiqueta Procel Edifica, da Eletrobrás; o Selo Casa Azul, da Caixa Econômica Federal; a certificação QUALIVERDE da Prefeitura do Rio de Janeiro, dentre outras.

As empresas estão buscando o enquadramento nas questões sustentáveis mas ainda há muito trabalho pela frente. Como principais desafios apontados pela CBIC (Câmara Brasileira da Indústria da Construção) na publicação do documento Desenvolvimento com Sustentabilidade estão:

a) valorização e desenvolvimento da mão de obra;

b) inovação tecnológica;

c) desenvolvimento urbano sustentável.

Para que os objetivos sejam atingidos, o setor precisa atuar de forma conjunta. Questões sociais, legais, tributárias e institucionais devem ser debatidas a exaustão para que se atenda o maior número possível de interessados.

"Para que a construção seja sustentável surge, também o desafio da qualificação das empresas no diálogo contínuo e frutífero com seus variados steakeholders". (Guia CBIC de boas práticas em sustentabilidade na indústria da construção, 2012).

\section{3 \\ Contexto atual da construção civil na cidade do Rio de Janeiro e o incremento da Alvenaria Estrutural}

Atualmente na cidade do Rio de Janeiro aproximadamente 15 grandes construtoras constituem a maior fatia do mercado imobiliário, sendo as demais de pequeno porte e com participação pontual.

Em 25 de março de 2009 foi lançado pelo governo federal o programa Minha Casa Minha Vida, com a finalidade de criar mecanismos de incentivo à 
produção e aquisição de 1 milhão de novas unidades habitacionais, atualmente essa meta é de 2 milhões de novas moradias para as famílias com renda bruta mensal de até $\mathrm{R} \$ 5.000,00$.

A partir desse programa as construtoras, de um modo geral, passaram a investir no mercado de construção popular, muitas vezes criando marcas e equipes próprias para desenvolver e divulgar os produtos.

Algumas já detinham a tecnologia e já estavam consolidadas nessa fatia de mercado, outras buscavam ampliar seus negócios investindo nessa nova tipologia de empreendimentos.

A maioria dos empreendimentos voltados para esse público tinham como técnica construtiva a alvenaria estrutural. Normalmente são projetos mais simples, com plantas compactas e sem grandes possibilidades de alterações futuras.

Nesse período houve um grande aumento de projetos em desenvolvimento utilizando a alvenaria estrutural como método construtivo.

Os projetistas buscaram se especializar, pois a demanda por projetos era maior do que a disponibilidade de equipes.

As construtoras de maior porte passaram a utilizar a tecnologia da alvenaria estrutural em seus processos, e o têm usado em grande escala.

Tem-se observado o aumento da utilização desse padrão de construção não só nos empreendimentos para o público de baixa renda, como também para empreendimentos voltados para o público de maior poder aquisitivo, e até mesmo de padrão aquisitivo enquadrado como classe média, isso como forma de viabilizar os empreendimentos.

Além disso o método tem sido amplamente estudado e desenvolvido nas construtoras por ser eficaz com relação a algumas questões de sustentabilidade, assunto em evidência no momento e necessário para manter o equilíbrio do desenvolvimento sustentável.

As Tabelas 2.1 a 2.5 mostram os dados comparativos levantados através de pesquisa de campo, como padrão, número de unidades, área das unidades e localização, dos principais empreendimentos residenciais lançados entre 2008 e 2012 na cidade do Rio de Janeiro e a utilização do sistema em alvenaria estrutural.

Para a determinação do padrão do empreendimento leva-se em consideração o VGV (valor geral de vendas) que é calculado pela soma do valor potencial de venda de todas as unidades de um empreendimento. 
Por meio das tabelas poderemos verificar a evolução da utilização do sistema nos empreendimentos ao longo desses anos.

Tabela 2.1 - Principais empreendimentos residenciais lançados em 2008.

\begin{tabular}{|c|c|c|c|c|c|}
\hline Empreendimento & Bairro & Padrão & $\mathrm{N}^{\circ}$ unids. & Área unids. & $\begin{array}{l}\text { Alvenaria } \\
\text { estrutural }\end{array}$ \\
\hline Park Rossete & $\begin{array}{l}\text { Campo } \\
\text { Grande }\end{array}$ & Popular & 192 & $33 / 46 \mathrm{~m}^{2}$ & Sim \\
\hline Park Ritz & $\begin{array}{l}\text { Campo } \\
\text { Grande }\end{array}$ & Popular & 192 & $33 / 46 m^{2}$ & Sim \\
\hline $\begin{array}{c}\text { Mais Residencial } \\
\text { Clube }\end{array}$ & Pechincha & Emergente & 468 & $59 / 70 \mathrm{~m}^{2}$ & Sim \\
\hline Reserva do Parque & $\begin{array}{l}\text { Barra da } \\
\text { Tijuca }\end{array}$ & Médio & 1258 & $74 / 115 \mathrm{~m}^{2}$ & Nāo \\
\hline Estrelas & $\begin{array}{l}\text { Barra da } \\
\text { Tijuca }\end{array}$ & Médio & 992 & $62 / 77 \mathrm{~m}^{2}$ & Nāo \\
\hline Arboretto & Cachambi & Emergente & 222 & $49 / 57 \mathrm{~m}^{2}$ & Sim \\
\hline Reserva Jardim & $\begin{array}{l}\text { Barra da } \\
\text { Tijuca }\end{array}$ & Médio & 1292 & $78 / 150 \mathrm{~m}^{2}$ & Nāo \\
\hline Barra Mais & $\begin{array}{l}\text { Barra da } \\
\text { Tijuca }\end{array}$ & Médio & 180 & $57 / 83 \mathrm{~m}^{2}$ & Nāo \\
\hline Avant Garde & Freguesia & Médio & 154 & $60 / 78 \mathrm{~m}^{2}$ & Não \\
\hline Gávea Green & Sāo Conrado & Alto & 38 & $\begin{array}{c}380 / \\
1220 \mathrm{~m}^{2}\end{array}$ & Nāo \\
\hline Máximo Recreio & Recreio & Médio & 192 & $95 / 293 \mathrm{~m}^{2}$ & Nāo \\
\hline Arena Park & Mèier & Emergente & 989 & $59 / 115 \mathrm{~m}^{2}$ & Nāo \\
\hline Quinta do Conde & Sāo Cristovāo & Médio & 220 & $59 / 83 \mathrm{~m}^{2}$ & Nāo \\
\hline Jardins do Recreio & Recreio & Médio-Alto & 450 & $103 / 114 \mathrm{~m}^{2}$ & Nāo \\
\hline High Residence & Freguesia & Médio & 136 & $57 / 74 \mathrm{~m}^{2}$ & Não \\
\hline
\end{tabular}

Tabela 2.2 - Principais empreendimentos residenciais lançados em 2009.

\begin{tabular}{|c|c|c|c|c|c|}
\hline Empreendimento & Bairro & Padrão & $\mathrm{N}^{\circ}$ unids. & Área unids. & $\begin{array}{l}\text { Alvenaria } \\
\text { estrutural }\end{array}$ \\
\hline Morada Carioca & Sāo Cristovāo & Emergente & 144 & $45 / 46 \mathrm{~m}^{2}$ & Sim \\
\hline Villa do Rio & Vila da Penha & Emergente & 156 & $44 / 53 \mathrm{~m}^{2}$ & Nāo \\
\hline Parque dos Sonhos & $\begin{array}{l}\text { Campo } \\
\text { Grande }\end{array}$ & Popular & 300 & $48 / 56 \mathrm{~m}^{2}$ & Sim \\
\hline Vila Guaratiba & Guaratiba & Popular & 120 & $45 / 56 \mathrm{~m}^{2}$ & Sim \\
\hline Vila Cachamorra & $\begin{array}{l}\text { Campo } \\
\text { Grande }\end{array}$ & Popular & 440 & $45 / 56 \mathrm{~m}^{2}$ & Sim \\
\hline Vila Cordovil & $\begin{array}{c}\text { Parada de } \\
\text { Lucas }\end{array}$ & Popular & 440 & $45 / 55 \mathrm{~m}^{2}$ & Sim \\
\hline Vila Guandu Sapê & $\begin{array}{l}\text { Campo } \\
\text { Grande }\end{array}$ & Popular & 380 & $45 / 56 \mathrm{~m}^{2}$ & Sim \\
\hline Norte Parque & Méier & Popular & 497 & $47 / 98 \mathrm{~m}^{2}$ & Sim \\
\hline
\end{tabular}


Tabela 2.2 - Continuação.

\begin{tabular}{|c|c|c|c|c|c|}
\hline Empreendimento & Bairro & Padrão & $\mathrm{N}^{\circ}$ unids. & Área unids. & $\begin{array}{l}\text { Alvenaria } \\
\text { estrutural }\end{array}$ \\
\hline Tudo Azul & Irajá & Popular & 236 & $44 / 49 \mathrm{~m}^{2}$ & Sim \\
\hline Park Riviera da Costa & $\begin{array}{l}\text { Campo } \\
\text { Grande }\end{array}$ & Popular & 237 & $37 / 57 \mathrm{~m}^{2}$ & Sim \\
\hline $\begin{array}{l}\text { Residencial América } \\
\text { Life }\end{array}$ & $\begin{array}{l}\text { Jardim } \\
\text { América }\end{array}$ & Popular & 139 & $42 / 71 \mathrm{~m}^{2}$ & Sim \\
\hline Maraville & Taquara & Popular & 658 & $50 / 51 \mathrm{~m}^{2}$ & Sim \\
\hline Alegria & Taquara & Emergente & 294 & $58 / 156 \mathrm{~m}^{2}$ & Sim \\
\hline Palazzo Imperial & Freguesia & Médio-Alto & 84 & $79 / 116 \mathrm{~m}^{2}$ & Nāo \\
\hline Mais São Cristovão & Sāo Cristovāo & Emergente & 211 & $48 / 107 \mathrm{~m}^{2}$ & Sim \\
\hline Conde de Bragança & Tijuca & Médio & 120 & $57 / 79 \mathrm{~m}^{2}$ & Nāo \\
\hline $\begin{array}{c}\text { Richmond } \\
\text { Condominio Resort }\end{array}$ & Taquara & Emergente & 252 & $48 / 63 \mathrm{~m}^{2}$ & Sim \\
\hline Joia do Campo & $\begin{array}{l}\text { Campo } \\
\text { Grande }\end{array}$ & Popular & 295 & $49 / 96 m^{2}$ & Sim \\
\hline Jardim Europa & $\begin{array}{l}\text { Campo } \\
\text { Grande }\end{array}$ & Médio & 154 & $74 / 236 m^{2}$ & $\operatorname{Sim}$ \\
\hline Park Riviera do Sol & $\begin{array}{l}\text { Campo } \\
\text { grande }\end{array}$ & Popular & 237 & $37 / 57 \mathrm{~m}^{2}$ & Sim \\
\hline Vitality & $\begin{array}{l}\text { Barra da } \\
\text { Tijuca }\end{array}$ & Médio Alto & 354 & $67 / 178 \mathrm{~m}^{2}$ & Nāo \\
\hline Renaissance & Tijuca & Médio Alto & 56 & $98 / 105 \mathrm{~m}^{2}$ & Nāo \\
\hline $\begin{array}{c}\text { Life Resort Campo } \\
\text { Grande }\end{array}$ & $\begin{array}{l}\text { Campo } \\
\text { Grande }\end{array}$ & Emergente & 496 & $55 / 136 \mathrm{~m}^{2}$ & Sim \\
\hline Scenario Vieira Souto & Ipanema & Alto & 5 & $212 / 396 \mathrm{~m}^{2}$ & Nāo \\
\hline Reserva Freguesia & Freguesia & Médio Alto & 66 & $83 / 204 m^{2}$ & Nāo \\
\hline Ideal Quality Living & Gávea & Alto & 30 & $86 / 179 \mathrm{~m}^{2}$ & Nāo \\
\hline Galleria Paissandu & Flamengo & Alto & 18 & $159 / 370 \mathrm{~m}^{2}$ & Nāo \\
\hline Via Quintas do Lago & Praça Seca & Emergente & 288 & $41 / 70 \mathrm{~m}^{2}$ & Não \\
\hline Original Grajaú & Grajaú & Médio & 80 & $75 / 94 \mathrm{~m}^{2}$ & Nāo \\
\hline Vila Brasil & Benfica & Emergente & 192 & $44 / 93 \mathrm{~m}^{2}$ & Sim \\
\hline Option & Humaitá & Alto & 16 & $94 / 99 \mathrm{~m}^{2}$ & Nāo \\
\hline Griffe Botafogo & Botafogo & Alto & 37 & $92 / 96 \mathrm{~m}^{2}$ & Nāo \\
\hline Recanto Humaitá & Botafogo & Alto & 24 & $80 / 115 \mathrm{~m}^{2}$ & Nāo \\
\hline Le Quartier & $\begin{array}{l}\text { Barra da } \\
\text { Tijuca }\end{array}$ & Médio Alto & 188 & $71 / 196 \mathrm{~m}^{2}$ & Nāo \\
\hline
\end{tabular}

Tabela 2.3 - Principais empreendimentos residenciais lançados em 2010.

\begin{tabular}{|c|c|c|c|c|c|}
\hline Empreendimento & Bairro & Padrão & N $^{\circ}$ unids. & Área unids. & $\begin{array}{c}\text { Alvenaria } \\
\text { estrutural }\end{array}$ \\
\hline Sky Residencial & Freguesia & Médio & 68 & $49 / 159 \mathrm{~m}^{2}$ & Não \\
\hline Royal Blue & $\begin{array}{c}\text { Barra da } \\
\text { Tijuca }\end{array}$ & Alto & 210 & $169 / 217 \mathrm{~m}^{2}$ & Não \\
\hline Bora Bora Hills & Freguesia & Médio & 160 & $75 / 233 \mathrm{~m}^{2}$ & Não \\
\hline Florença Residence & Tijuca & Médio & 160 & $78 / 230 \mathrm{~m}^{2}$ & Não \\
\hline
\end{tabular}


Tabela 2.3 - Continuação.

\begin{tabular}{|c|c|c|c|c|c|}
\hline Empreendimento & Bairro & Padrāo & $\mathrm{N}^{\circ}$ unids. & Área unids. & $\begin{array}{l}\text { Alvenaria } \\
\text { estrutural }\end{array}$ \\
\hline Lèssence Laranjeiras & Laranjeiras & Alto & 36 & $77 / 213 \mathrm{~m}^{2}$ & Nāo \\
\hline Vila Bela & Taquara & Médio & 218 & $75 / 192 \mathrm{~m}^{2}$ & Nāo \\
\hline $\begin{array}{c}\text { Espaço Engenho Life } \\
\text { IV }\end{array}$ & $\begin{array}{l}\text { Engenho da } \\
\text { Rainha }\end{array}$ & Popular & 200 & $42 / 55 \mathrm{~m}^{2}$ & Sim \\
\hline Vistta Laguna & $\begin{array}{l}\text { Barra da } \\
\text { Tijuca }\end{array}$ & Alto & 128 & $171 / 464 \mathrm{~m}^{2}$ & Nāo \\
\hline $\begin{array}{l}\text { Sorocaba } 527 \text { All } \\
\text { Suites }\end{array}$ & Botafogo & Alto & 10 & $154 / 200 \mathrm{~m}^{2}$ & Nāo \\
\hline $\begin{array}{l}\text { Adryana Varandas } \\
\text { Residence }\end{array}$ & $\begin{array}{l}\text { Campo } \\
\text { Grande }\end{array}$ & Popular & 243 & $47 / 52 \mathrm{~m}^{2}$ & Sim \\
\hline Minha Praia & $\begin{array}{l}\text { Barra da } \\
\text { Tijuca }\end{array}$ & Popular & 1170 & $50 \mathrm{~m}^{2}$ & Sim \\
\hline Wish & $\begin{array}{l}\text { Barra da } \\
\text { Tijuca }\end{array}$ & Alto & 6 & $240 \mathrm{~m}^{2}$ & Não \\
\hline Premier Lagoa & Lagoa & Alto & 20 & $103 / 313 \mathrm{~m}^{2}$ & Não \\
\hline Verano Comfort Stay & $\begin{array}{l}\text { Barra da } \\
\text { Tijuca }\end{array}$ & Médio & 169 & $63 / 71 \mathrm{~m}^{2}$ & Nāo \\
\hline Vale do Sol Life & $\begin{array}{l}\text { Campo } \\
\text { Grande }\end{array}$ & Popular & 78 & $45 / 55 \mathrm{~m}^{2}$ & Sim \\
\hline Caminhos da Barra & Gardênia Azul & Popular & 920 & $48 \mathrm{~m}^{2}$ & Sim \\
\hline Design life Style & Botafogo & Alto & 33 & $97 / 204 \mathrm{~m}^{2}$ & Nāo \\
\hline $\begin{array}{c}\text { Residencial California } \\
\text { XIII }\end{array}$ & Bangu & Popular & 210 & $48 / 57 \mathrm{~m}^{2}$ & Sim \\
\hline Pátio Carioca & Vila da Penha & Emergente & 672 & $57 / 165 \mathrm{~m}^{2}$ & Nāo \\
\hline Park Renovare & $\begin{array}{l}\text { Campo } \\
\text { Grande }\end{array}$ & Popular & 128 & $45 / 68 \mathrm{~m}^{2}$ & Sim \\
\hline Boulevard Carioca & $\begin{array}{l}\text { Campo } \\
\text { Grande }\end{array}$ & Popular & 420 & $41 / 62 \mathrm{~m}^{2}$ & Sim \\
\hline Barra Acrópole & $\begin{array}{l}\text { Barra da } \\
\text { Tijuca }\end{array}$ & Médio & 56 & $85 \mathrm{~m}^{2}$ & Nāo \\
\hline Boa Nova & Cachambi & Popular & 364 & $45 / 51 \mathrm{~m}^{2}$ & Sim \\
\hline $\begin{array}{l}\text { Park Riviera do } \\
\text { Campo }\end{array}$ & Bangu & Popular & 499 & $45 \mathrm{~m}^{2}$ & Sim \\
\hline Bossa Norte & Madureira & Popular & 240 & $44 / 49 \mathrm{~m}^{2}$ & Sim \\
\hline Le Quartier Vert & Recreio & Médio & 180 & $71 / 196 \mathrm{~m}^{2}$ & Nāo \\
\hline Via Flamboyant & Jacarepaguá & Emergente & 214 & $58 / 69 \mathrm{~m}^{2}$ & Nāo \\
\hline Paysages Residence & Botafogo & Alto & 84 & $77 / 120 \mathrm{~m}^{2}$ & Nāo \\
\hline Estaçāo Carioca & Irajá & Popular & 160 & $42 / 55 \mathrm{~m}^{2}$ & Sim \\
\hline Golden Residence & Cachambi & Médio & 72 & $89 \mathrm{~m}^{2}$ & Nāo \\
\hline Riservato Botafogo & Botafogo & Alto & 36 & $90 \mathrm{~m}^{2}$ & Nāo \\
\hline Aloha & Recreio & Médio & 176 & $73 / 156 \mathrm{~m}^{2}$ & Nāo \\
\hline St. Barth & $\begin{array}{l}\text { Barra da } \\
\text { Tijuca }\end{array}$ & Alto & 330 & $220 / 402 \mathrm{~m}^{2}$ & Nāo \\
\hline Grand Family & $\begin{array}{l}\text { Barra da } \\
\text { Tijuca }\end{array}$ & Médio & 94 & $80 / 195 \mathrm{~m}^{2}$ & Nāo \\
\hline $\begin{array}{l}\text { Residencial Florença } \\
\text { Life }\end{array}$ & $\begin{array}{l}\text { Campo } \\
\text { Grande }\end{array}$ & Popular & 210 & $42 / 43 \mathrm{~m}^{2}$ & Sim \\
\hline Solar de Valença & Tijuca & Médio & 10 & $115 / 235 \mathrm{~m}^{2}$ & Nāo \\
\hline Village de Capri & Praça Seca & Emergente & 96 & $64 / 139 \mathrm{~m}^{2}$ & Nāo \\
\hline Nas Nuvens & Praça Seca & Popular & 189 & $42 / 100 \mathrm{~m}^{2}$ & Sim \\
\hline Botafogo Plus & Botafogo & Médio & 14 & $50 / 121 \mathrm{~m}^{2}$ & Não \\
\hline
\end{tabular}


Tabela 2.4 - Principais empreendimentos residenciais lançados em 2011.

\begin{tabular}{|c|c|c|c|c|c|}
\hline Empreendimento & Bairro & Padrão & $\mathrm{N}^{\circ}$ unids. & Área unids. & $\begin{array}{l}\text { Alvenaria } \\
\text { estrutural }\end{array}$ \\
\hline $\begin{array}{l}\text { América Condominio } \\
\text { Clube }\end{array}$ & Del Castilho & Emergente & 452 & $47 / 59 \mathrm{~m}^{2}$ & Não \\
\hline Lisboa & Pavuna & Emergente & 30 & $54 \mathrm{~m}^{2}$ & Sim \\
\hline Maayan & $\begin{array}{l}\text { Barra da } \\
\text { Tijuca }\end{array}$ & Médio & 1108 & $69 / 86 \mathrm{~m}^{2}$ & Nāo \\
\hline $\begin{array}{l}\text { Reserva Carioca } \\
\text { Residencial }\end{array}$ & $\begin{array}{l}\text { Barra da } \\
\text { Tijuca }\end{array}$ & Médio Alto & 216 & $72 / 84 \mathrm{~m}^{2}$ & Não \\
\hline Reserva Pontal & Recreio & Alto & 49 & $76 / 99 \mathrm{~m}^{2}$ & Nāo \\
\hline Rio Residencial & Del Castilho & Emergente & 350 & $47 / 62 \mathrm{~m}^{2}$ & Não \\
\hline Versailles & Freguesia & Médio Alto & 44 & $90 / 119 \mathrm{~m}^{2}$ & Não \\
\hline Vila das Fontes & Vila da Penha & Emergente & 533 & $56 / 75 \mathrm{~m}^{2}$ & Nāo \\
\hline Submime & Recreio & Médio & 870 & $63 / 113 \mathrm{~m}^{2}$ & Nāo \\
\hline Viverde Residencial & Recreio & Médio & 322 & $63 / 211 \mathrm{~m}^{2}$ & Sim \\
\hline
\end{tabular}

Tabela 2.5 - Principais empreendimentos residenciais lançados em 2012.

\begin{tabular}{|c|c|c|c|c|c|}
\hline Empreendimento & Bairro & Padrão & $\mathrm{N}^{\circ}$ unids. & Área unids. & $\begin{array}{l}\text { Alvenaria } \\
\text { estrutural }\end{array}$ \\
\hline $360^{\circ}$ On the Park & $\begin{array}{l}\text { Barra da } \\
\text { Tijuca }\end{array}$ & Alto & 300 & $154 / 193 \mathrm{~m}^{2}$ & Nāo \\
\hline Adorabile & Tijuca & Médio & 126 & $57 / 78 \mathrm{~m}^{2}$ & Não \\
\hline Alphaland & $\begin{array}{l}\text { Barra da } \\
\text { Tijuca }\end{array}$ & Alto & 210 & $80 / 120 \mathrm{~m}^{2}$ & Nāo \\
\hline Bourgogne & Freguesia & Médio Alto & 272 & $67 / 86 \mathrm{~m}^{2}$ & Nāo \\
\hline Concetto & Recreio & Médio Alto & 192 & $72 / 83 \mathrm{~m}^{2}$ & Não \\
\hline Dez & $\begin{array}{l}\text { Rocha } \\
\text { Miranda }\end{array}$ & Emergente & 112 & $46 / 47 \mathrm{~m}^{2}$ & Sim \\
\hline Essence & $\begin{array}{l}\text { Barra da } \\
\text { Tijuca }\end{array}$ & Médio Alto & 362 & $73 / 155 \mathrm{~m}^{2}$ & Nāo \\
\hline Evidence & Taquara & Médio & 154 & $60 / 76 \mathrm{~m}^{2}$ & Nāo \\
\hline Focus Tijuca & Tijuca & Médio Alto & 84 & $98 / 100 \mathrm{~m}^{2}$ & Nāo \\
\hline Font Vielle & $\begin{array}{l}\text { Barra da } \\
\text { Tijuca }\end{array}$ & Alto & 90 & $276 / 552 \mathrm{~m}^{2}$ & Nāo \\
\hline $\begin{array}{l}\text { Freedom Club } \\
\text { Residencial }\end{array}$ & Freguesia & Médio Alto & 314 & $74 / 107 \mathrm{~m}^{2}$ & Nāo \\
\hline Fun Residencial & Cachambi & Emergente & 164 & $51 / 67 \mathrm{~m}^{2}$ & Sim \\
\hline Golden Tijuca & Tijuca & Médio Alto & 60 & $94 / 114 \mathrm{~m}^{2}$ & Não \\
\hline Grand Araguaia & Freguesia & Médio Alto & 55 & $94 / 418 \mathrm{~m}^{2}$ & Nāo \\
\hline Magnific & Freguesia & Médio & 61 & $67 / 95 \mathrm{~m}^{2}$ & Nāo \\
\hline Marmaris & Recreio & Médio Alto & 10 & $75 / 106 \mathrm{~m}^{2}$ & Não \\
\hline Mérito & $\begin{array}{l}\text { Engenho } \\
\text { Novo }\end{array}$ & Emergente & 96 & $48 / 55 \mathrm{~m}^{2}$ & Sim \\
\hline Mio Residencial Park & Jacarepaguá & Médio & 658 & $65 / 85 \mathrm{~m}^{2}$ & Nāo \\
\hline Onda Carioca & Recreio & Médio Alto & 438 & $68 / 107 \mathrm{~m}^{2}$ & Nāo \\
\hline Park Premium & Recreio & Médio Alto & 444 & $79 / 97 \mathrm{~m}^{2}$ & Não \\
\hline
\end{tabular}


Tabela 2.5 - Continuação.

\begin{tabular}{|c|c|c|c|c|c|}
\hline Empreendimento & Bairro & Padräo & $\mathrm{N}^{\circ}$ unids. & Área unids. & $\begin{array}{l}\text { Alvenaria } \\
\text { estrutural }\end{array}$ \\
\hline Scena Laguna & $\begin{array}{l}\text { Barra da } \\
\text { Tijuca }\end{array}$ & Alto & 70 & $156 \mathrm{~m}^{2}$ & Nāo \\
\hline Tijuca Uno & Tijuca & Médio Alto & 70 & $68 / 93 \mathrm{~m}^{2}$ & Nāo \\
\hline Union Square & $\begin{array}{l}\text { Barra da } \\
\text { Tijuca }\end{array}$ & Médio Alto & 670 & $78 / 96 \mathrm{~m}^{2}$ & Nāo \\
\hline Vernissage & Pechincha & Médio & 10 & $60 / 109 \mathrm{~m}^{2}$ & Nāo \\
\hline Vila Esplendida & Vila da Penha & Médio & 208 & $85 / 98 \mathrm{~m}^{2}$ & Nāo \\
\hline Village Vert & Freguesia & Médio Alto & 195 & $74 / 107 \mathrm{~m}^{2}$ & Nāo \\
\hline
\end{tabular}

$\mathrm{Na}$ Figura 2.11 a seguir observamos a quantidade dos principais empreendimentos lançados entre 2008 e 2012 por padrão. Nos anos de 2009 e 2010 vê-se um aumento vertiginoso de lançamentos de empreendimentos de padrão popular impulsionados pelo programa Minha Casa Minha Vida do governo federal. Em 2010, tem destaque a quantidade de lançamentos de padrão médio e de padrão alto refletindo o crescimento do mercado em direção ao centro da cidade, à zona sul e aos bairros do Recreio dos Bandeirantes e Vargens. Em 2012 muitos empreendimentos de padrão médio foram lançados nos bairros do Recreio, Jacarepaguá e Barra da Tijuca (próximo ao autódromo).

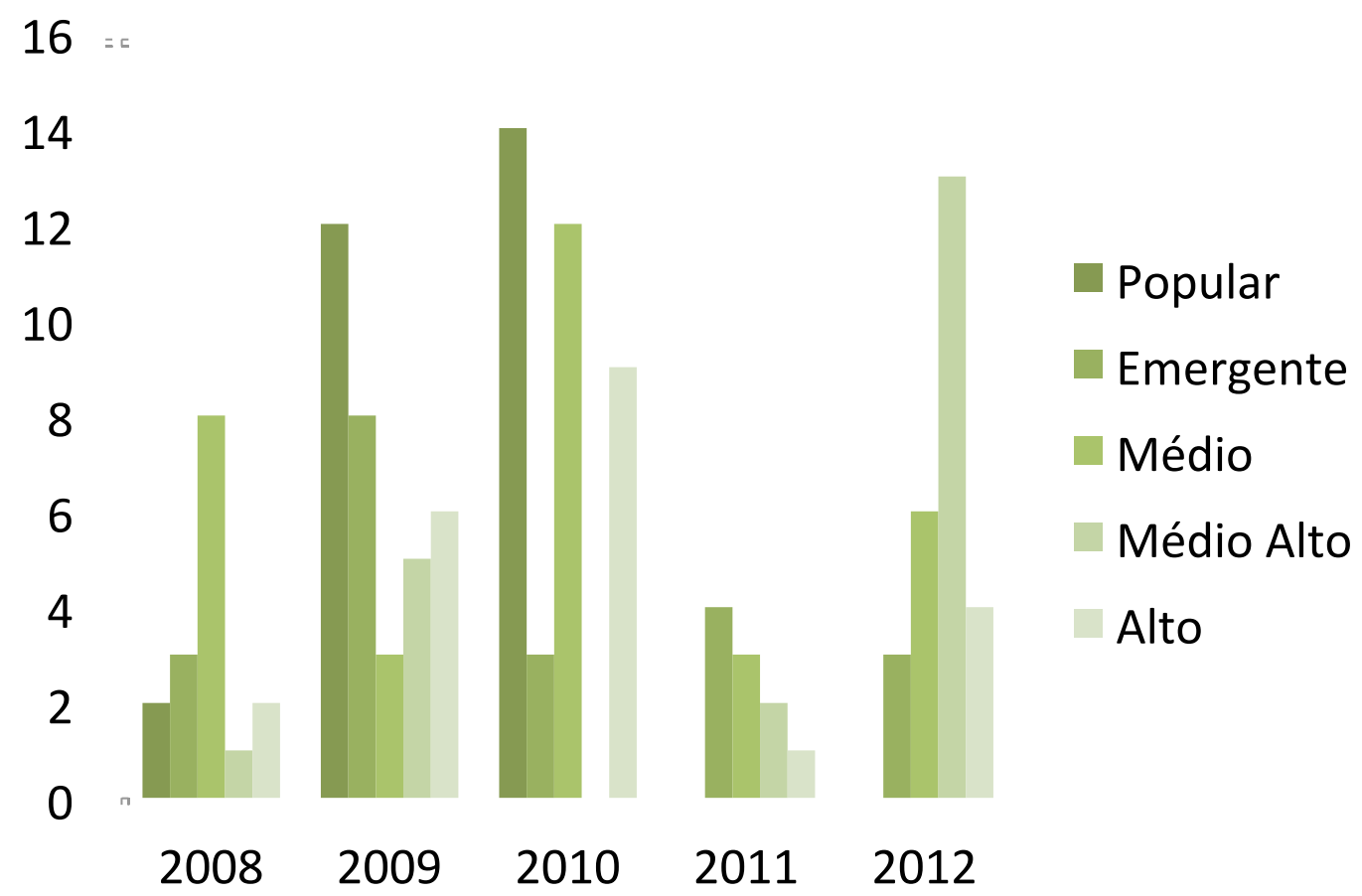

Figura 2.11 - Principais empreendimentos lançados entre 2008 e 2012 por padrão. 
$\mathrm{Na}$ Figura 2.12 a seguir temos a quantidade dos principais empreendimentos lançados entre 2008 e 2012 por bairro e região. Nos anos de 2009 e 2010 vê-se o aumento de lançamentos na Zona Norte também impulsionados pelo programa Minha Casa Minha Vida. A Zona Oeste tem destaque entre 2009 e 2010. A zona sul apresenta maior número de lançamentos em 2010 que já vinham acontecendo desde 2009. Em 2012 os lançamentos se concentraram nos bairros da Barra, Jacarepaguá e Zona Norte.

\section{4}

12

10

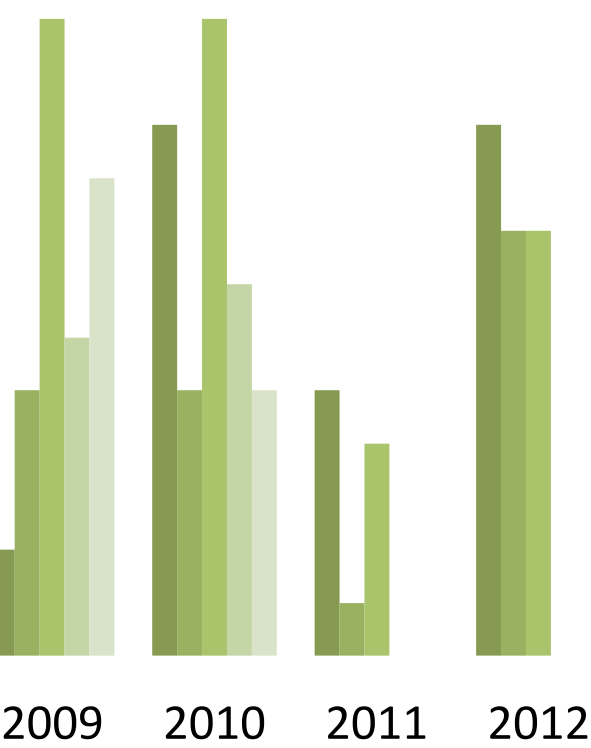

Barra/Recreio

- Jacarepaguá

Zona Norte

Zona Sul

Zona Oeste

0

\section{$2008 \quad 2009 \quad 2010 \quad 2011 \quad 2012$}

Figura 2.12 - Principais empreendimentos lançados entre 2008 e 2012 por bairro/região.

A Figura 2.13 informa a quantidade dos principais empreendimentos lançados entre 2008 e 2012 por sistema construtivo. Nele pode-se observar o aumento do número de construções com o sistema em alvenaria estrutural nos anos de 2009 e 2010 , reforçando as informações das figuras 2.11 e 2.12. 


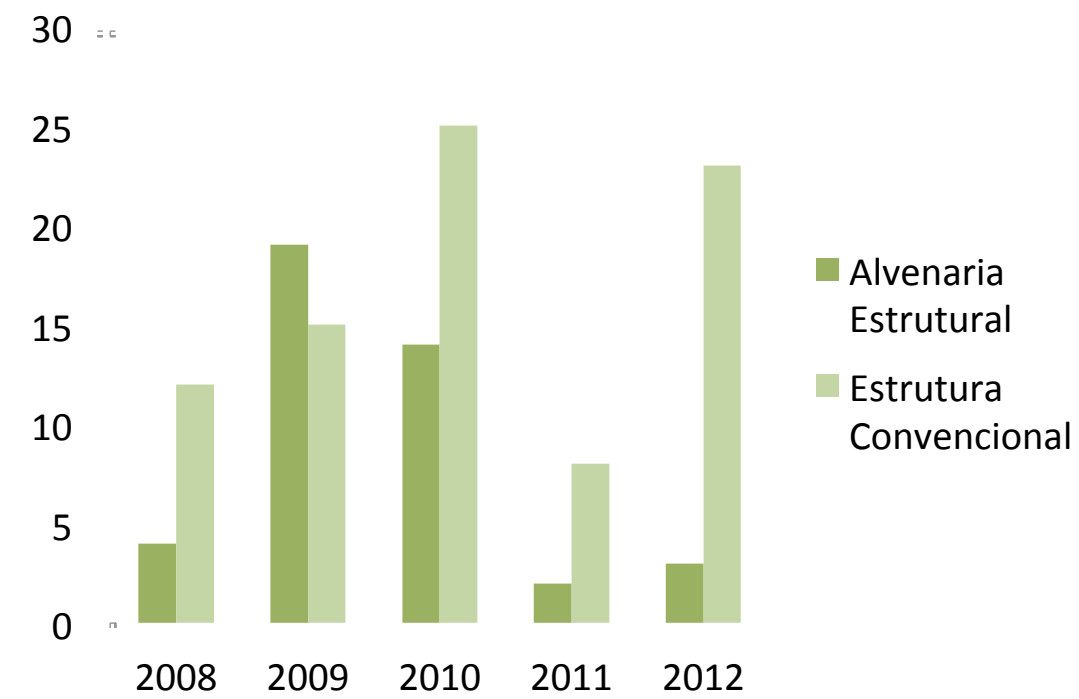

Figura 2.13 - Principais empreendimentos lançados entre 2008 e 2012 por sistema construtivo.

A Figura 2.14 a seguir traz a quantidade aproximada de área construída referente aos empreendimentos em alvenaria estrutural lançados entre 2008 e 2012. Nesses cinco anos o total de área construída atingiu quase $767.000,00 \mathrm{~m}^{2}$. Para se chegar a esse valor foi considerado o acréscimo de $20 \%$ em relação ao somatório de área privativa levantada.

Levando-se em consideração que as obras em alvenaria estrutural têm uma redução de custo de aproximadamente $20 \%$ em relação ao sistema de estrutura convencional de concreto armado, e considerando-se o CUB em torno de R\$ $1.100,00 / \mathrm{m}^{2}$, houve uma economia de quase R\$169.000.000,00 de 2008 a 2012.

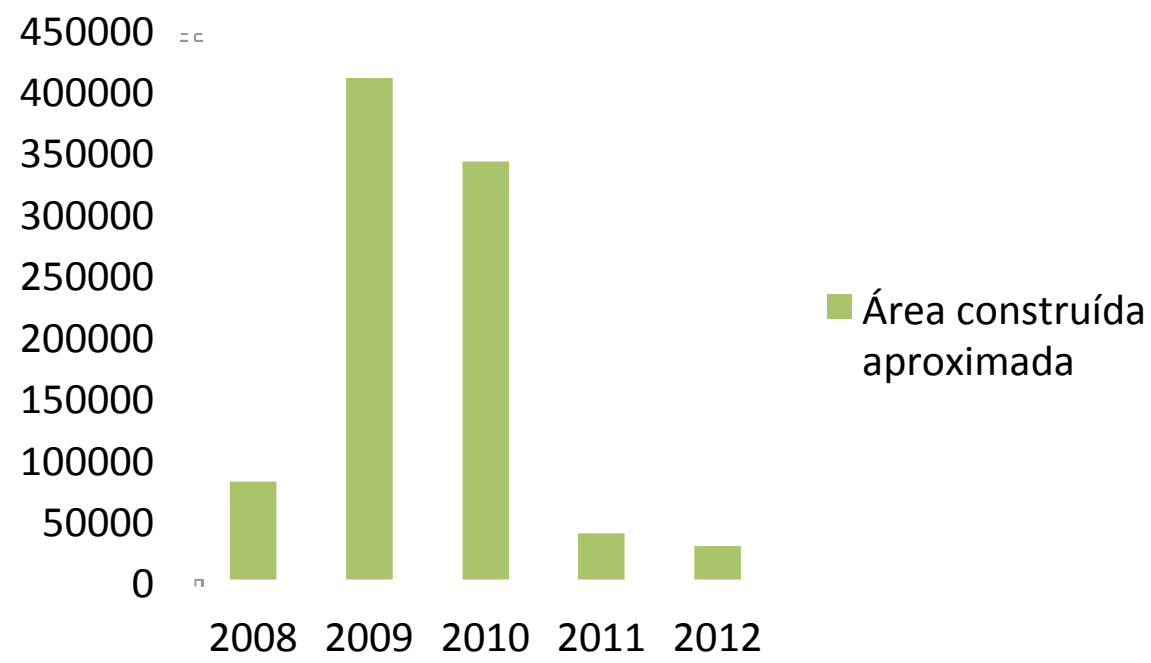

Figura 2.14 - Total aproximado de área construída referente aos lançamentos em alvenaria estrutural entre 2008 e 2012. 
Na Figura 2.15 a seguir pode-se observar a economia a cada ano com a diferença entre o custo dos empreendimentos em alvenaria estrutural e uma simulação caso os mesmos fossem em estrutura convencional de concreto armado.

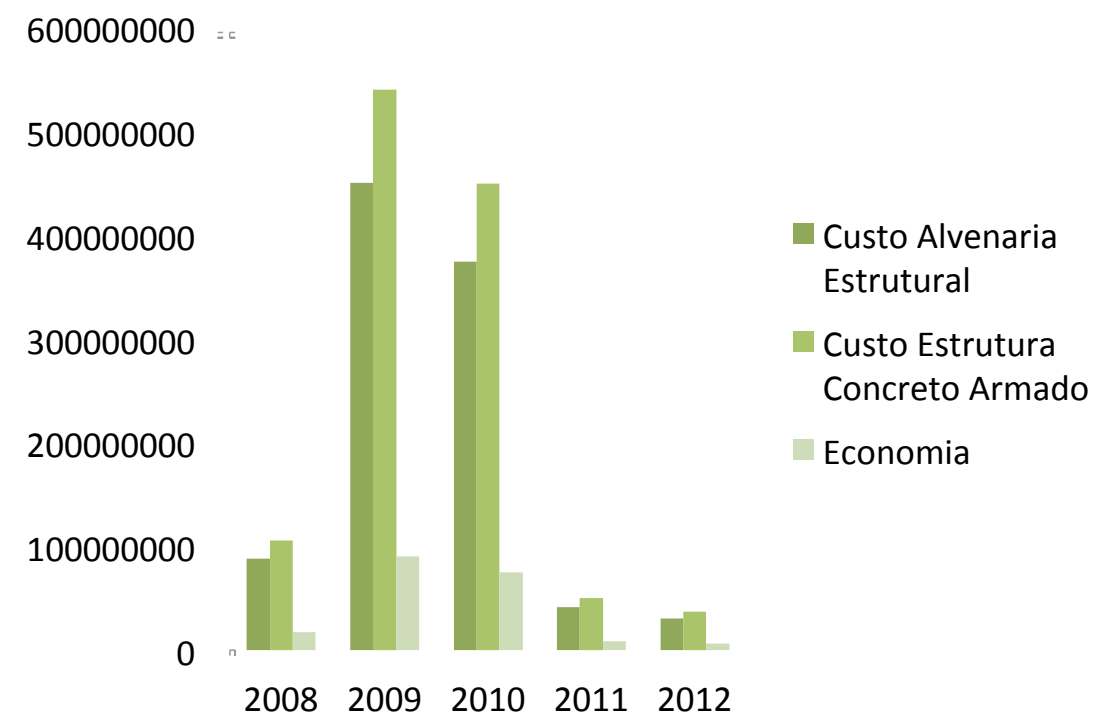

Figura 2.15 - Custo aproximado do total de área construída referente aos lançamentos em alvenaria estrutural entre 2008 e 2012 e economia em relação ao sistema de estrutura convencional em concreto armado.

Essa economia também se reflete na economia de recursos. Obras em estrutura convencional de concreto armado consomem mais cimento, aço e formas.

A alvenaria estrutural também reduz emissões de $\mathrm{CO}_{2}$. $\mathrm{Na}$ estrutura convencional as emissões ocorrem desde a produção do material até o transporte. Além disso, na alvenaria estrutural o volume de resíduos chega a ser em torno de $30 \%$ menor. 


\section{3 \\ Sistema construtivo em alvenaria estrutural}

\section{1 Histórico do sistema construtivo em alvenaria estrutural}

A alvenaria é um sistema construtivo cuja utilização remonta no início da atividade humana ( 4.000 a.C) na construção de estruturas para variados fins. Foram empregados blocos de vários materiais tais como argila, pedra e outros, e destes blocos foram produzidas obras que desafiaram o tempo e, mesmo após séculos e em alguns casos até milênio, estão presentes nos dias atuais como verdadeiros monumentos com grande importância histórica (FIGUEIRÓ, 2009).

Foi por volta do século XVII que a alvenaria estrutural passou a ser tratada como uma tecnologia de construção civil. Nessa época foram aplicados os princípios de estática para a investigação da estabilidade de arcos e domos. No período entre os séculos XIX e XX foram realizados testes de resistência dos elementos da alvenaria estrutural em vários países, mas o projeto de alvenaria estrutural era elaborado de acordo com métodos empíricos de cálculo, apresentando grandes limitações. Os edifícios em alvenaria estrutural eram construídos com paredes muito mais espessas do que o necessário (HENDRY, 2002).

Ainda nesse período a perda de espaço e a baixa velocidade de produção desfavoreciam a adesão de edifícios altos em alvenaria estrutural, que também era intensificada pela emergente alternativa de estruturas de concreto armado. Durante um período de 50 anos esse método construtivo teve pouca aplicação (HENDRY, 2002).

$\mathrm{Na}$ década de 50 foi retomado o interesse pela construção em alvenaria estrutural. A Segunda Guerra Mundial impulsionou essa retomada, pois causou a escassez de materiais de construção na Europa, principalmente do aço. Muitos edifícios foram construídos em Alvenaria Estrutural nessa época na Suíça, devido à indisponibilidade de aço na região (HENDRY, 2002). Através de estudos realizados pelo professor suíço Paul Haller com testes em mais de 1600 paredes de tijolos, foi possível projetar um prédio de 18 pavimentos com espessuras de 
paredes que variavam entre 30 e $38 \mathrm{~cm}$, espessuras bastante reduzidas para a época e que geraram uma revolução no processo existente até então.

\subsection{1}

\section{Edificações históricas em Alvenaria Estrutural}

As pirâmides de Gizé, localizadas nos arredores do Cairo, no Egito são três grandes pirâmides construídas em blocos de pedra e datam de aproximadamente 2.600 a.C. (Figura 3.1). A grande pirâmide, conhecida como pirâmide de Queóps, mede $147 \mathrm{~m}$ de altura e sua base é um quadrado de $230 \mathrm{~m}$ de lado. Foram utilizados 2,3 milhões de blocos, com peso médio de $25 \mathrm{kN}$. A construção se deu pela colocação dos blocos uns sobre os outros (FIGUEIRÓ, 2009).

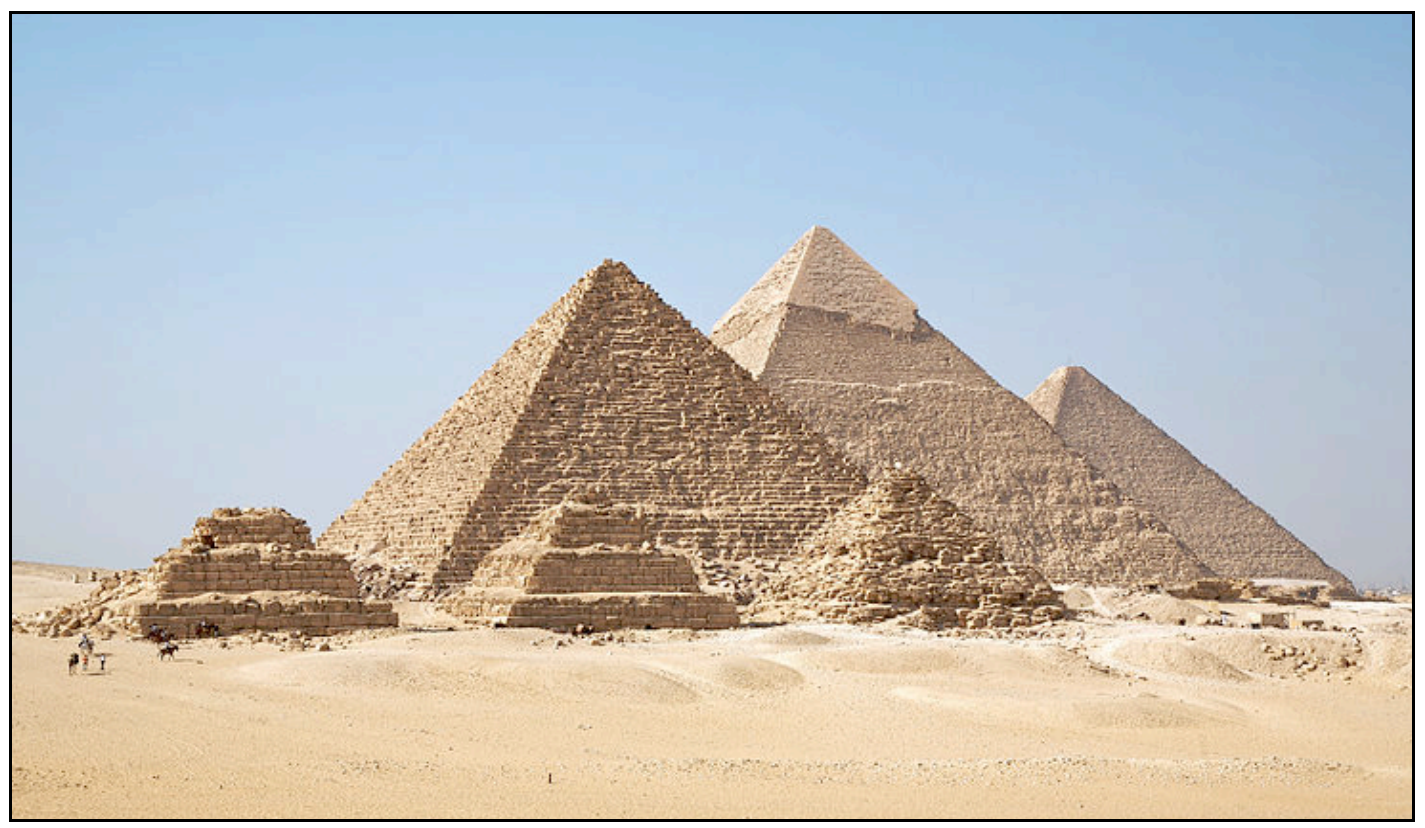

Figura 3.1 - Pirâmides de Guizé; http://arz.wikipedia.org/wiki/جلف:All_ Gizah_Pyramids.jpg, visitado em: 13/01/2013.

O Coliseu é um grande anfiteatro com capacidade para até 50 mil pessoas com mais de $500 \mathrm{~m}$ de diâmetro e $50 \mathrm{~m}$ de altura (Figura 3.2). Construído por volta do ano 70 d.C., no centro de Roma, possuía inúmeros arcos que permitiam vencer grandes vãos suportando tensões que não levassem o material a ruptura (FIGUEIRÓ, 2009). 


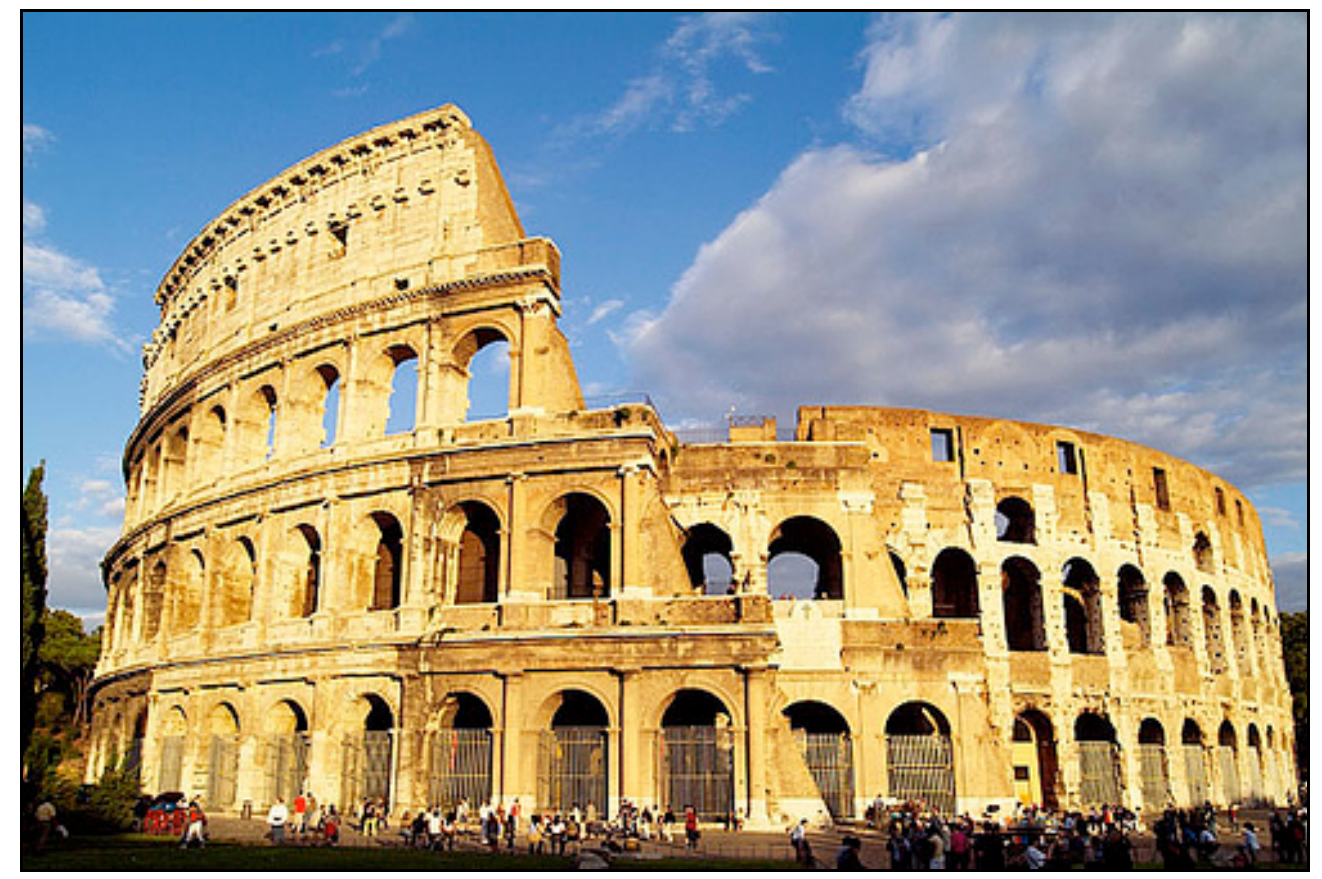

Figura 3.2 - Coliseo; http://losmejoreslugares.galeon.com/elcoliseoromani.html, visitado em: 13/01/2013.

A catedral de Reims na França é um grande exemplo de catedral gótica construída entre 1211 e 1300 d.C. Demonstra a aprimorada técnica de se conseguir vãos relativamente grandes utilizando-se apenas estruturas comprimidas (Figura 3.3). O seu interior é amplo, com arcos que sustentam o teto sendo apoiado em pilares esbeltos que, por sua vez, são contraventados por arcos externos (FIGUEIRÓ, 2009).

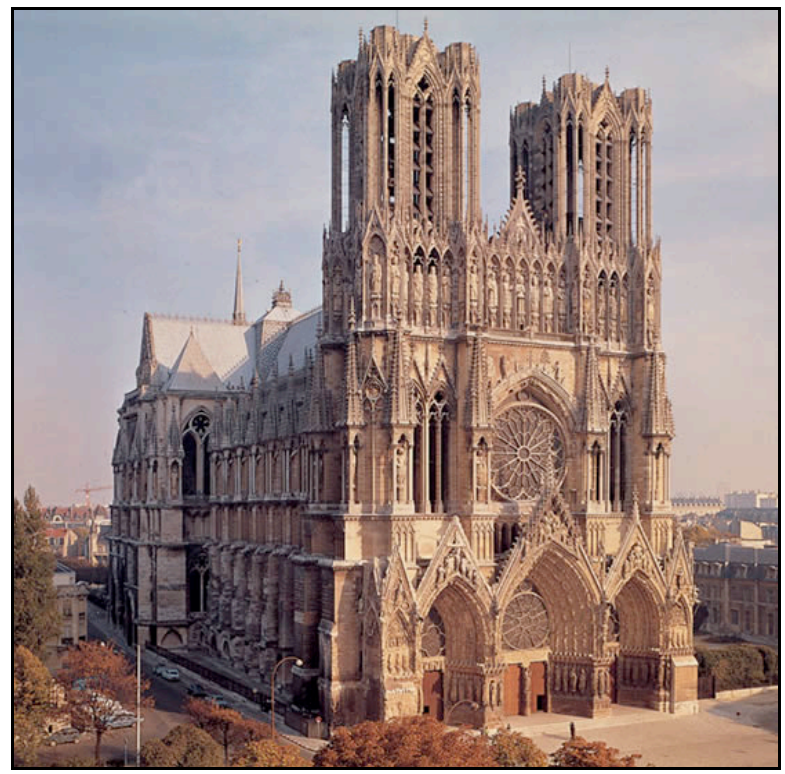

Figura 3.3 - Catedral de Reims; http://arte.laguia2000.com/arquitectura/atedral-de-reims, visitado em 13/01/2013. 
O edifício Monadnock, construído na cidade de Chicago (EUA) entre 1889 e 1891, tornou-se um símbolo clássico da moderna alvenaria estrutural. Com 16 pavimentos e 65 metros de altura foi considerada uma obra ousada (Figura 3.4). Pela utilização de métodos empíricos no cálculo empregado na época, as paredes na base têm 1,80 m de espessura. Acredita-se que calculado pelos métodos atuais e utilizando os mesmos materiais, essas paredes teriam no máximo $30 \mathrm{~cm}$ de espessura (FIGUEIRÓ, 2009).

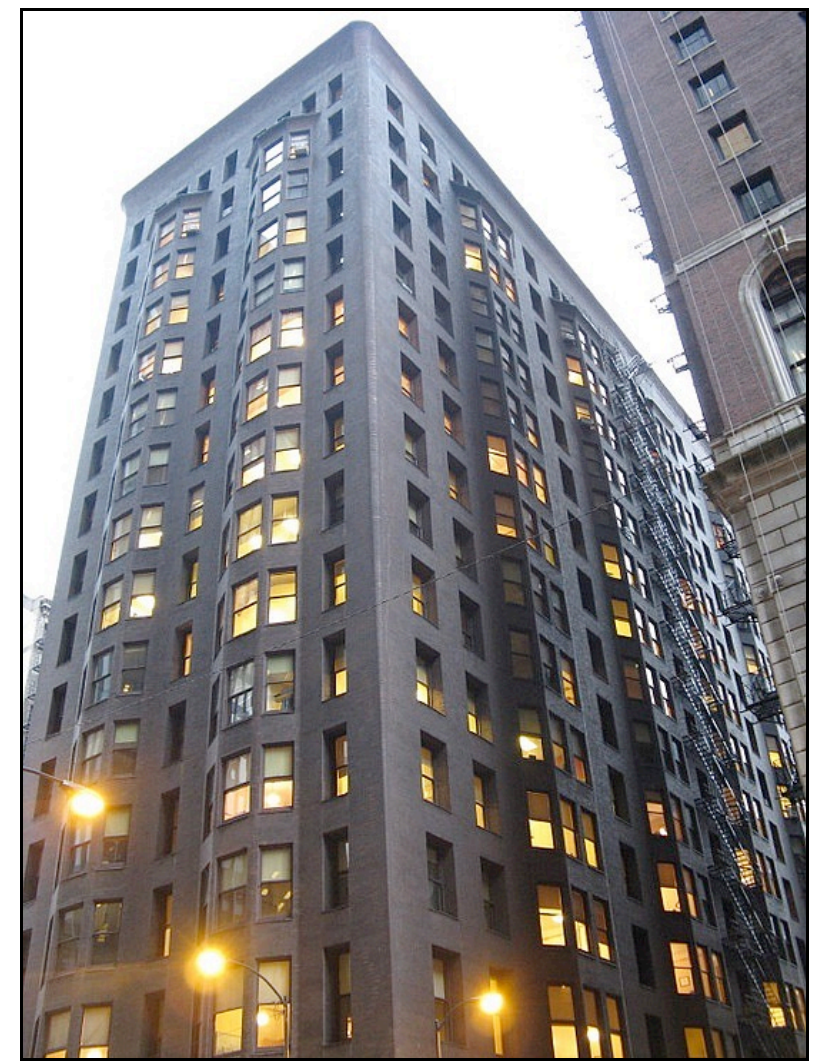

Figura 3.4 - Edifício Monadnock; http://wdict.net/word/monadnock+bulding/, visitado em $13 / 01 / 2013$

O Hotel Excalibur (Figura 3.5) localizado em Las Vegas nos Estados Unidos é considerado o mais alto edifício em alvenaria estrutural da atualidade. São quatro torres principais, com 28 pavimentos cada. As paredes estruturais foram executadas em alvenaria armada de blocos de concreto e a resistência à compressão especificada na base foi de 28 MPa (FIGUEIRÓ, 2009). 


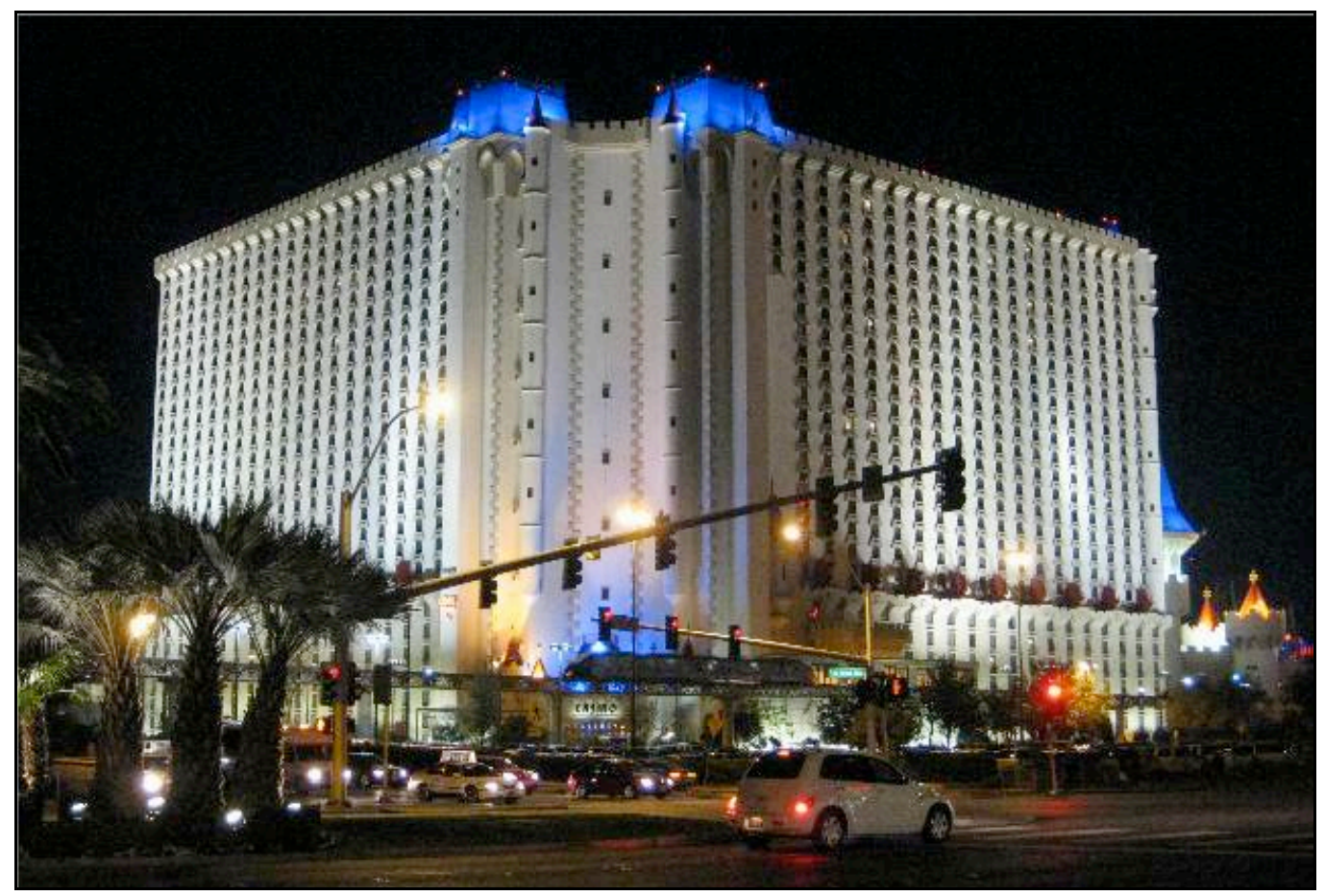

Figura 3.5 - Hotel Excalibur; http://www.lasvegasgateway.com/excalibur-hotel.html, visitado em 13/01/2013.

\subsection{2 \\ Edificações em Alvenaria Estrutural no Brasil}

No Brasil a alvenaria é utilizada desde o início da colonização portuguesa no início do século XVI, porém, sem ser um processo construtivo econômico e racional. Levou algum tempo para que esse tipo de método ganhasse espaço e importância (RAMALHO e CORRÊA, 2003).

Foi a partir da década de 70 que a alvenaria estrutural passou a ser considerada uma tecnologia de engenharia no Brasil, com projetos estruturais baseados em princípios validados cientificamente. Apesar da sua adoção tardia, a tecnologia se firmou como alternativa eficiente e econômica para a execução de edifícios residenciais e industriais (RAMALHO e CORRÊA, 2003). À essa época a tecnologia ainda era precária, e ficou relacionada pejorativamente às construções econômicas de baixa qualidade, sendo portanto, somente na década de 1980 a sua consolidação por meio de normalização oficial após anos de adaptação e desenvolvimento (SABATTINI, 2003). 
A utilização do sistema em alvenaria estrutural só ocorreu em 1966 na cidade de São Paulo em edifícios de 4 pavimentos do conjunto habitacional Central Park Lapa. A obra foi realizada com paredes de espessura de $19 \mathrm{~cm}$.

Em 1972 edifícios mais elevados de 12 pavimentos em alvenaria armada de bloco de concreto começaram a ser construídos também em São Paulo no mesmo conjunto habitacional (FIGUEIRÓ, 2009).

Atualmente há uma crescente tendência de utilização desse processo no Brasil, principalmente em empreendimentos habitacionais de baixa renda, que surgiram em grande escala após a divulgação do programa do governo Minha Casa Minha Vida.

Muitas construtoras estão aplicando o método construtivo não somente em construções residenciais de baixa renda, como também em edifícios de padrão melhor e padrão médio-superior como forma de viabilizar custo, prazo e garantir a qualidade do produto final.

\section{2 \\ Conceituação do sistema}

Segundo FIGUEIRÓ (2009) as definições antigas acerca do processo construtivo em alvenaria estrutural consideravam que as construções eram formadas de pedras naturais ou artificiais ligadas entre si de modo estável pela combinação das juntas e interposição de argamassa (ou somente por um desses meios), suscetíveis de resistirem unicamente aos esforços de compressão.

Atualmente construções em alvenaria estrutural são formadas por blocos industrializados de diversos materiais suscetíveis de serem projetadas e dimensionadas por meio de procedimentos de cálculo para suportar cargas, ligados entre si pela interposição de argamassa e podendo ainda conter armadura envolta em graute no plano horizontal e/ou vertical.

A alvenaria estrutural pode ser classificada em:

a) armada - por necessidade estrutural, os elementos resistentes possuem uma armadura passiva de aço que será disposta na cavidade dos blocos e serão preenchidas com graute (microconcreto); 
b) não armada - as armaduras só existem nos elementos estruturais com finalidades construtivas para prevenção de problemas patológicos (fissuras, concentração de tensões etc);

c) parcialmente armada - alguns elementos resistentes são projetados como armados e outros como não armados;

d) protendida - o elemento resistente contém uma armadura ativa de aço.

\section{3 \\ Estudo dos materiais}

No início, as construções eram executadas com pedra ou com tijolos de argila ou cerâmicos secos ao sol com técnica baseada em métodos empíricos. As paredes eram muito espessas, uma vez que eram desconhecidas as características de resistência dos materiais.

O sistema construtivo em alvenaria estrutural foi o que mais evoluiu tecnicamente nos últimos anos com o emprego de novos materiais através do estudo e cálculo das resistências dos mesmos. Atualmente as paredes são formadas pela união de diferentes componentes conforme descrições a seguir.

\subsection{1 \\ Componentes do sistema construtivo}

Um componente da alvenaria estrutural é uma entidade básica que irá compor os elementos da estrutura. Os componentes principais são: blocos (ou unidades); argamassa; graute e armadura. Os elementos (pilares, cintas, vergas etc) são formados por pelo menos dois componentes.

A seguir, as descrições de cada componentes de acordo com RAMALHO e CORRÊA (2003) e conforme significado que têm na NBR 10837:1989.

\subsubsection{1}

\section{Unidade}

As unidades (blocos) são os componentes básicos da alvenaria estrutural. São responsáveis pela definição das características resistentes da estrutura. 
No Brasil as unidades são em blocos de concreto, blocos cerâmicos ou silico-calcáreos.

Quando maciços e com índice de vazios de no máximo $25 \%$ da área total, são denominados blocos maciços e quando vazados, ultrapassam esse percentual e são denominados blocos vazados.

Quanto à aplicação as unidades podem ser classificadas como de vedação e estruturais. De acordo com a NBR 6136:2014 a resistência do bloco a compressão deve obedecer aos seguintes limites:

$f_{\mathrm{bk}} \geq 6 M P a:$ blocos em paredes externas sem revestimento;

$f_{\mathrm{bk}} \geq 4,5 \mathrm{MPa}$ : blocos em paredes internas ou externas com revestimento.

A NBR 15270:2005 estabelece que para os blocos cerâmicos com função estrutural a resistência mínima à compressão deve ser de $3 \mathrm{MPa}$.

As Figuras 3.7 e 3.8 mostram exemplos de blocos cerâmicos e de blocos de concreto.

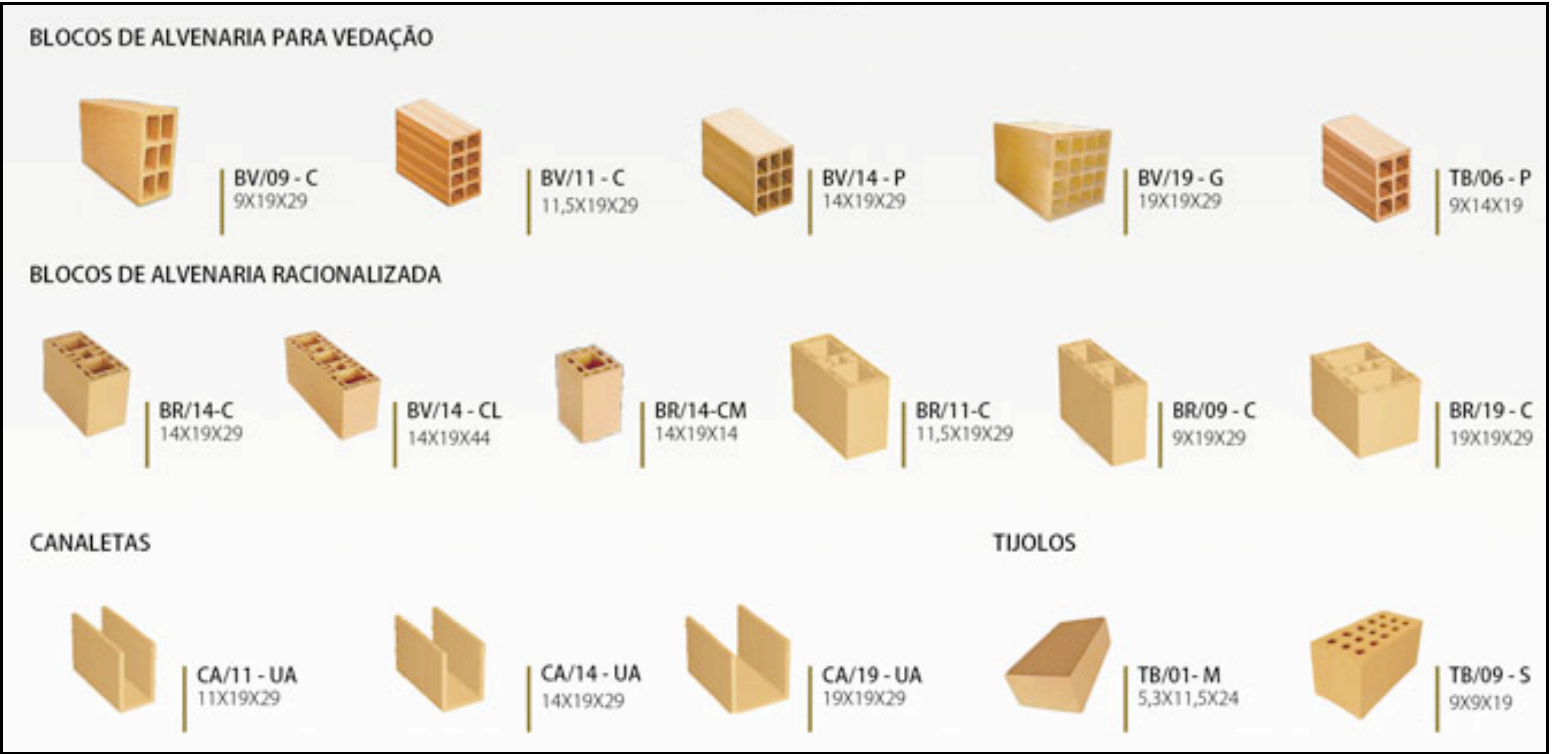

Figura 3.6 - Exemplo de blocos cerâmicos; http://site.grupobohm.com.br, visitado em: $12 / 01 / 2013$. 


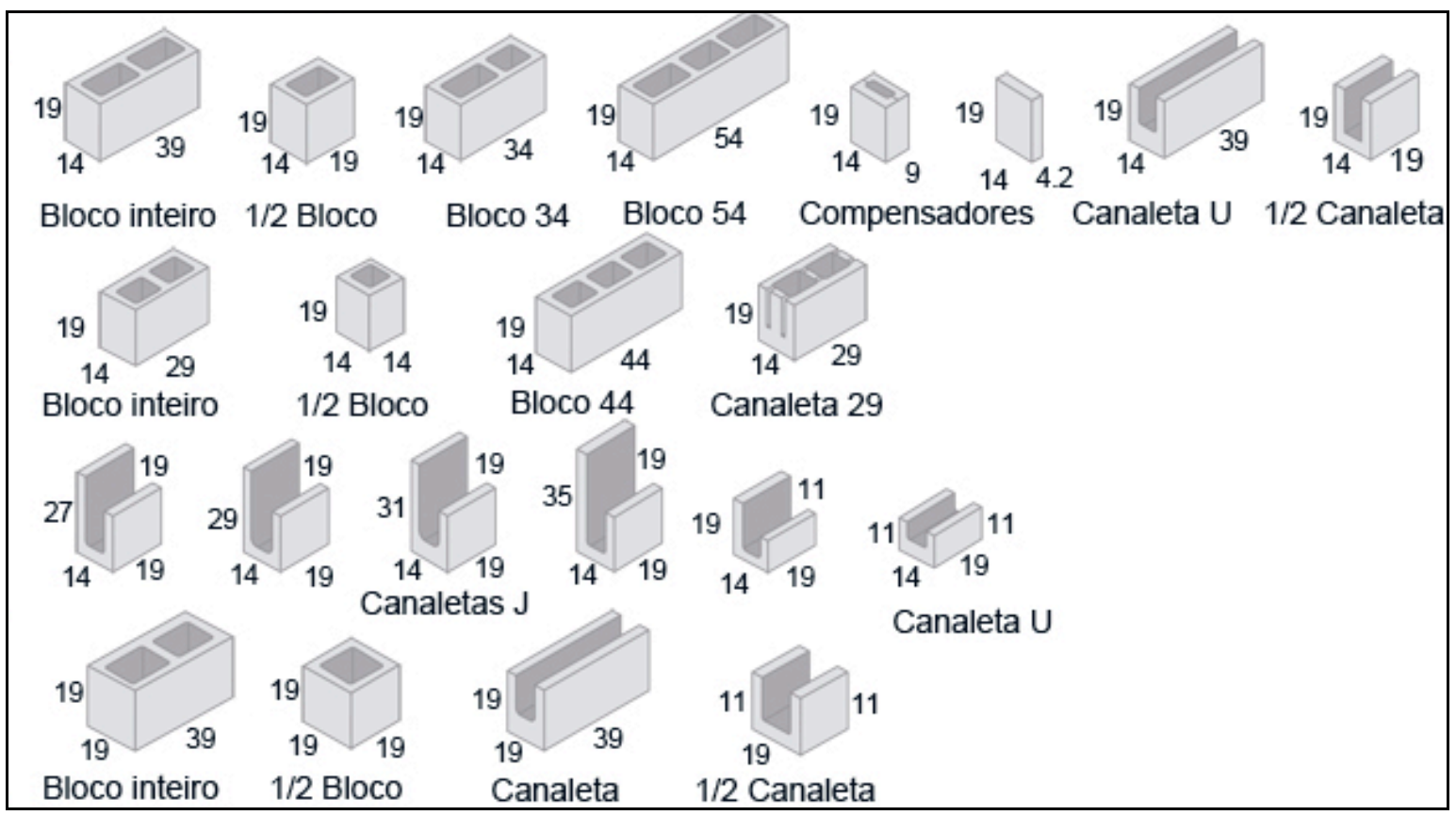

Figura 3.7 - Exemplo de blocos de concreto; http://pavertech.com.br/blocos, visitado em $12 / 01 / 2013$

\subsubsection{2 \\ Argamassa}

A argamassa de assentamento normalmente é composta de areia, cimento, cal e água e é responsável em unificar as unidades, transmitir e uniformizar as tensões entre as mesmas, assimilar pequenas deformações e vedar a entrada de água e de vento nas edificações.

\subsubsection{3}

Armaduras

São as barras de aço utilizadas nas construções em alvenaria estrutural. São as mesmas utilizadas nas estruturas de concreto armado, mas nesse caso estão sempre envolvidas por graute para garantir o trabalho conjunto com o restante dos componentes da alvenaria.

\subsubsection{4 \\ Graute}

O graute é um micro concreto muito fluido com agregados de pequena dimensão. Tem a função de propiciar o aumento da área da seção transversal das 
unidades ou unir os blocos com eventuais armaduras posicionadas nos seus vazios.

\subsection{2}

\section{Materiais alternativos}

Segundo MAMEDE (2001) alguns materiais alternativos têm sido estudados também para o sistema construtivo em alvenaria estrutural, como as fibras de polipropileno, o agregado leve e o concreto reciclado. Essas novas soluções vêm se apresentando como inovadoras, viáveis e interessantes. Porém, encontram relutância em sua utilização por parte dos construtores por falta de conhecimento sobre os benefícios, falta de domínio da tecnologia ou receio de investimento sem retorno.

\subsubsection{1 \\ Bloco de concreto reforçado com fibras de polipropileno}

Para se obter o bloco de concreto reforçado com fibras de polipropileno, as mesmas são adicionadas a matriz de cimento a uma quantidade máxima de $1 \% \mathrm{em}$ volume.

Adições inferiores de volume de fibra, como $0,5 \%$, têm mostrado eficiência na resistência ao impacto, segundo MAMEDE (2001) e TEZUCA (1989).

A utilização de blocos de concreto com adição de fibras de polipropileno na alvenaria estrutural pode apresentar vantagens como redução da massa do bloco tornando-o mais leve para o assentamento e redução dos esforços permanentes da estrutura.

\subsubsection{2}

\section{Concreto leve}

O concreto leve é obtido através da substituição do agregado comum por agregado com massa específica reduzida, tornando-o capaz de produzir um elemento pré-moldado mais leve e de fácil manuseio pela mão de obra. Os agregados comumente utilizados são: a escória de alto forno, a cinza volante e a argila expandida (MAMEDE, 2001). 
O emprego de elementos pré-moldados com concreto leve deve ser minuciosamente analisado através de estudo detalhado sobre as características do concreto para se evitar problemas de resistência inapropriada para o fim desejado.

\title{
3.3.2.3
}

\section{Concreto reciclado}

Segundo MAMEDE (2001) atualmente há a viabilidade de aproveitamento do entulho reciclado oriundo da construção e da demolição em diversos serviços nas edificações e em infraestrutura urbana. Agregados miúdos e graúdos podem ser usados em concretos não estruturais, em pré-moldados leves como blocos de vedação e de pavimentação para tráfego leve, em argamassas de revestimento, em agregados ensacados para contenção de taludes e canalização de córregos e em leitos de vias públicas e estradas.

\begin{abstract}
"A reciclagem do entulho pode ser realizada em sistemas descentralizados, ou seja, usinas de reciclagem, ou no canteiro de obra. No canteiro, o equipamento necessário é de médio porte, conhecido como moinho. Geralmente são empregados os moinhos de rolo que são equipamentos simples, cuja função é moer os agregados e misturar argamassas.

A reciclagem de canteiro traz como benefícios a economia com o transporte de resíduos e bota-fora até os locais de aterro, e a possibilidade de haver controle sobre a qualidade do resíduo.

Para o uso do material reciclado como agregado, é importante determinar suas características fisicas, tais como, granulometria, massa específica e massa unitária; escolher o traço e verificar a resistência dos concretos ou argamassas, respeitando-se as especificações das normas brasileiras." (MAMEDE, 2001).
\end{abstract}

Antes da adoção do agregado reciclado é recomendável a avaliação da quantidade de entulho gerado de acordo com a fase da obra para confirmar se será suficiente para a adoção da tecnologia.

A Figura 3.8 a seguir, ilustra o exemplo de um equipamento para a reciclagem de entulhos e resíduos da construção civil. 


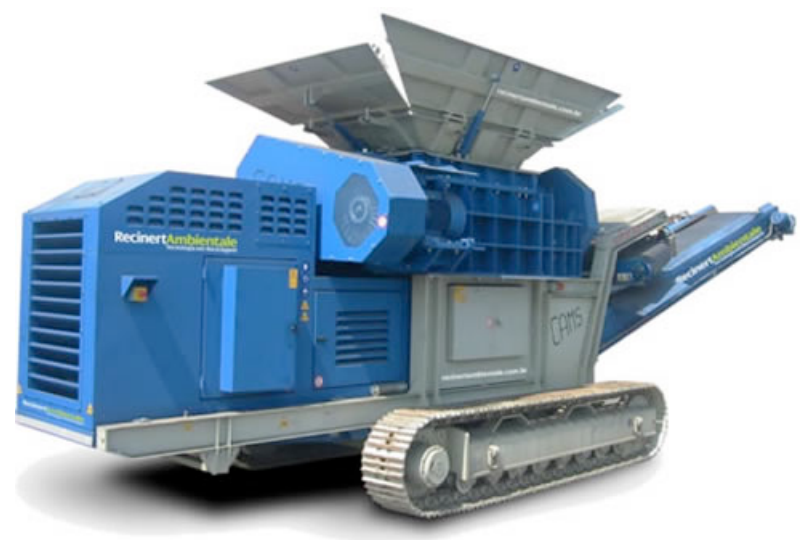

Figura 3.8 - Exemplo de equipamento para a reciclagem de entulhos e resíduos da construção civil; http://www.recinertambientale.com.br/site/?page_id=10, visitado em: 03/02/2013.

Independente do sistema estrutural do empreendimento, as construtoras têm se conscientizado e buscado fornecedores que façam toda a gestão de reciclagem dos resíduos do canteiro de obras, com o objetivo de reduzir o volume de entulho gerado minimizando os impactos ambientais das atividades do setor.

No interior dos canteiros são previstas caçambas específicas para o depósito dos resíduos de acordo com a sua categoria. Há também em alguns casos, pontos de coleta nos diversos pavimentos das obras para que os resíduos já cheguem nas caçambas devidamente separados.

Em uma obra em alvenaria estrutura, a separação se dá de forma mais eficaz, uma vez que a variedade de materiais é menor.

Além do entulho gerado pelos materiais componentes da alvenaria estrutural (concreto, argamassa, blocos de concreto etc) as empresas contratadas fazem a gestão de todo o resíduo gerado pela obra.

Também há casos em que a construtora disponibiliza a possibilidade de coleta seletiva para a comunidade do entorno através de pontos de coleta no tapume. A obra faz um comunicado aos vizinhos informando sobre a possibilidade de depositar os resíduos recicláveis nas baias localizadas no tapume e contrata empresa que faça a coleta.

A Figura 3.9 mostra um exemplo de tapume de obras que disponibiliza a coleta seletiva para a comunidade do entorno. 


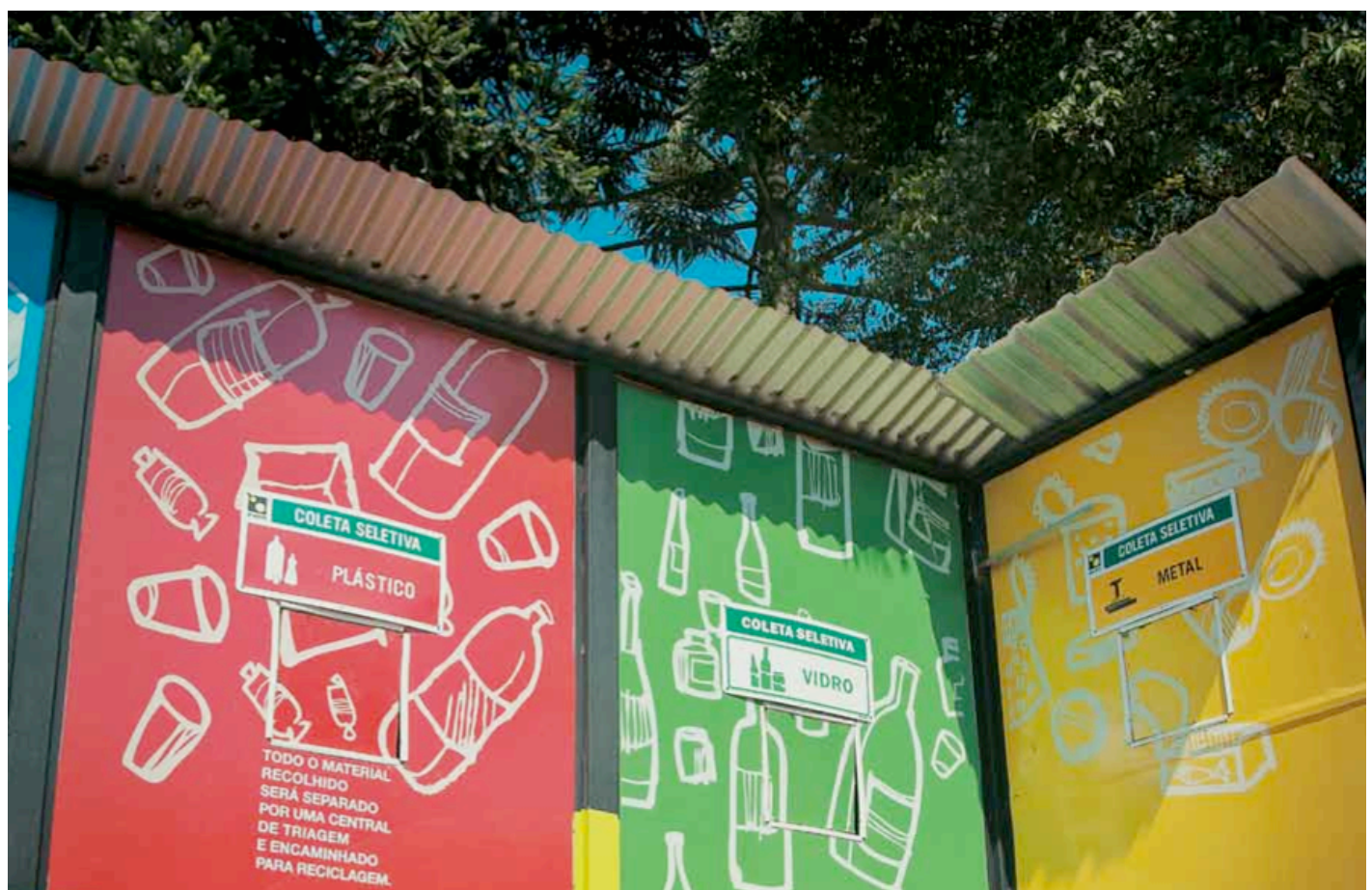

Figura 3.9 - Exemplo de tapume de obras com coleta seletiva;

http://www.even.com.br/sustentabilidade/downloads/even-rs2011.pdf, visitado em: 03/02/2013.

Algumas empresas que fazem a coleta possuem parcerias com ONGs que reciclam o material coletado transformando em diversos produtos.

As Figuras 3.10 e 3.11 seguir mostram o ciclo dos entulhos na construção civil com e sem reciclagem, independente do sistema estrutural utilizado.

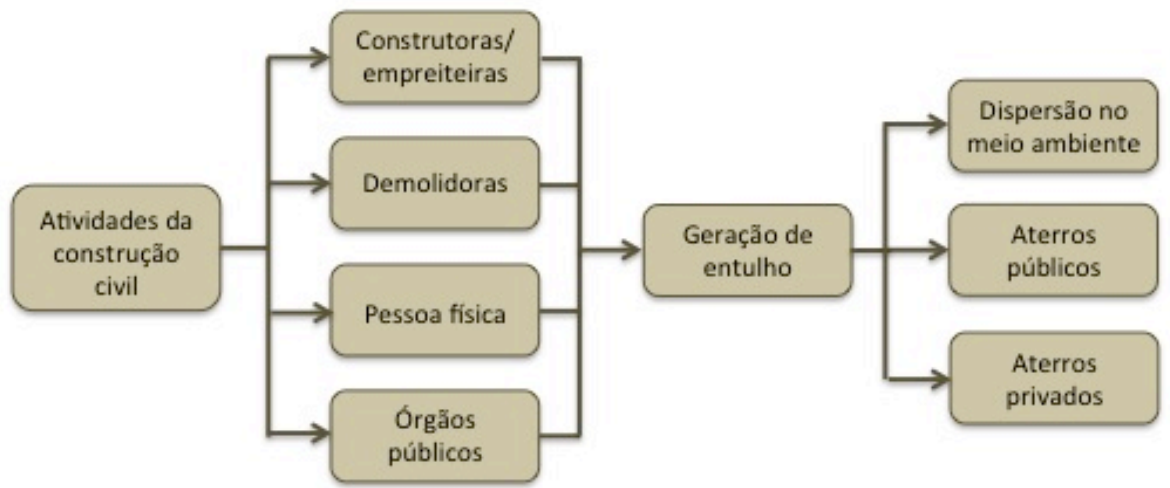

Figura 3.10 - Ciclo dos resíduos da construção civil sem reciclagem;

http://www.recinertambientale.com.br/site/?page_id=8, visitado em: 03/02/2013. 


\section{Ciclo}

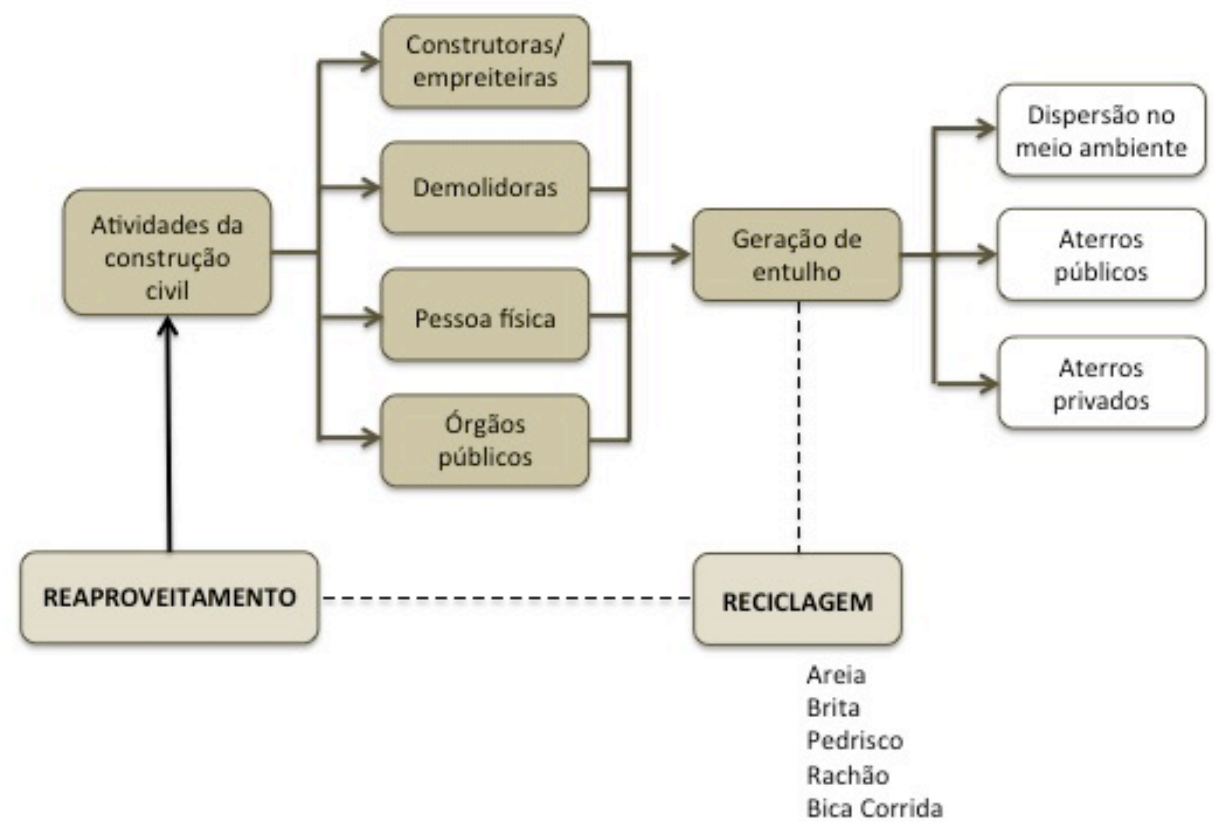

Figura 3.11 - Ciclo dos resíduos da construção civil com reciclagem;

http://www.recinertambientale.com.br/site/?page_id=8, visitado em: 03/02/2013.

\section{4 Modulação}

Os estudos desenvolvidos por vários setores da indústria e das instituições acadêmicas buscam definir as necessidades e as soluções para a cadeia da construção civil no Brasil.

O setor de insumos necessita melhorar a produtividade e a qualidade, além de aumentar o valor agregado. A cadeia produtiva busca aumentar a produtividade, reduzir o custo dos insumos, e ao mesmo tempo estar em conformidade com as normas vigentes. Enquanto isso o consumidor final anseia por edificações de melhor qualidade e menor preço (MARQUES, 2009).

Uma das formas de atingir esses objetivos é a busca da racionalização e industrialização da construção, de tal maneira que a construção de edificações possa aplicar efetivamente as melhores práticas tanto no projeto como na produção.

As edificações são projetadas não mais com o paradigma da produção em massa, mas em sintonia com o pensamento atual em sistemas de produção, a 
customização em massa. Em suma, procura-se permitir que o usuário possa efetivamente escolher o habitar que melhor se aproxima de seus anseios individuais e, ao mesmo tempo, possibilitar um processo de projeto e produção com baixos níveis de perdas. Para que isso seja possível é imprescindível, entre outras coisas, que os insumos estejam em conformidade com as normas e que estas contemplem os conceitos de Coordenação Modular. Além disso esses conceitos devem ser incorporados nas práticas dos outros participantes da cadeia produtiva: os projetistas e os construtores (MARQUES, 2009).

Atualmente a necessidade de redução de custos e de aumento da produtividade faz com que os processos de racionalização e compatibilização construtiva e dimensional sejam amplamente utilizados (MARQUES, 2009).

O Brasil foi um dos primeiros países do mundo a aprovar uma norma de Coordenação Modular com módulo de $10 \mathrm{~cm}$, a NB-25R, versão de 1950 (MARQUES, 2009).

Para que a construção civil torne-se apta a desempenhar o papel a que é exigida pela realidade atual, é necessário que esteja capacitada a produzir edificações que, além de respeitarem condições indispensáveis como habitabilidade, funcionalidade, durabilidade, segurança e acabamento, também apresentem características relacionadas à produtividade, condições adequadas de construção, baixo custo e desempenho ambiental, que são quesitos de grande importância, que atualmente representam um desafio para os profissionais da área.

As questões econômicas dizem respeito à redução de custos em várias etapas do processo construtivo. A redução de custos ocorre seja por otimização do uso da matéria-prima, seja pela agilidade no processo de decisão de projeto ou compra dos componentes, seja por aumento da produtividade, seja por diminuição das perdas.

Com relação à sustentabilidade a utilização da modulação traz um melhor aproveitamento dos componentes construtivos, e em consequência disso leva à otimização do consumo de matérias-primas, de consumo energético para produção desses componentes, e de sobras desses componentes em função dos inúmeros cortes na etapa de construção. YEANG (1999) faz um balanço dos inputs (insumos) e outputs (produtos) da construção civil, sendo que $40 \%$ das matériasprimas (por peso) do mundo são usadas na construção de edificações a cada ano; 
$36 \%$ a $45 \%$ do input de energia de uma nação é usado nas edificações, e $20 \%$ a $26 \%$ do lixo de aterros vêm das construções.

\subsection{1}

\section{Aspectos Históricos da Modulação}

"Historicamente, o uso de um módulo aparece na Arquitetura em uma interpretação clássica dos gregos, sob um caráter estético; dos romanos, sob um caráter estético-funcional; e dos japoneses, sob um caráter funcional” (MARQUES, 2009).

Para a unidade básica das dimensões dos gregos era utilizado o diâmetro da coluna. A partir desse módulo, criavam-se todas as demais dimensões: o da própria coluna (fuste, base e capitel) e o espaçamento entre elas (Figura 3.12). Na arquitetura grega, o vão da esquina era menor em relação aos demais vãos para que os componentes pré-fabricados se mantivessem com a mesma dimensão (MARQUES, 2009).

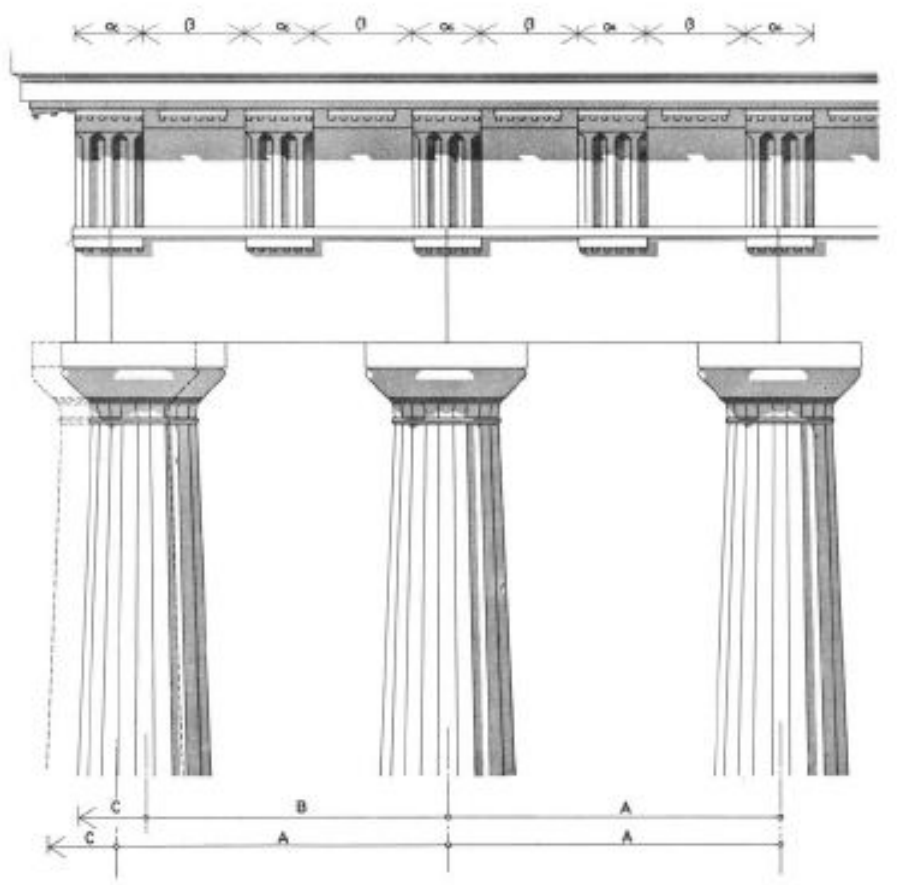

Figura 3.12 - Vãos normais e de esquina na arquitetura grega (MARQUES, 2009) 
"Os romanos serviram-se do módulo para estabelecer medidas tanto de componentes construtivos (tubos cerâmicos, telhas, tijolos, colunas e ladrilhos) como para utensílios domésticos (copos e pratos).

Dessa forma, conseguiram aplicar uma modulação flexível desde o pequeno componente até a grande cidade” (MARQUES, 2009).

A Tabela 3.1 mostra as medidas modulares romanas.

Tabela 3.1 - Medidas modulares romanas (MARQUES, 2009 baseada em BAUDAUF, 2004).

\begin{tabular}{l|l}
\multicolumn{1}{c}{ Componentes } & \multicolumn{1}{c|}{ Dimensōes } \\
\hline Tubo cerâmico para água & $\begin{array}{l}\text { Comprimento modular: } 1 \text { gradu (passo) } \\
\text { Comprimento a largura modulares: } \\
1 \text { cubitu (osso longo situado na face interna do antebraço) }=6 \\
\text { palmi (palma: porção da mão entre o punho e os dedos) }\end{array}$ \\
\hline Imbrex & Comprimento modular: 1 cubitu = 6 palmi \\
\hline $\begin{array}{l}\text { Laje de tijolos para hypocausto } \\
\text { (sistema de calefação) }\end{array}$ & $\begin{array}{l}\text { Comprimento e largura modulares: } 1 \text { bipedals (2 pés) }=8 \\
\text { (palmi) }\end{array}$ \\
\hline Tijolo tydica & Largura modula: 1 semis = 2 palmi \\
\hline $\begin{array}{l}\text { Vários ladrilhos quadrados } \\
\text { para pisos }\end{array}$ & $\begin{array}{l}\text { Altura modular: } 2 \text { pedes }=8 \text { palmi modulares }=1 \text { cubitu quadrado ou } 1 \text { pés quadrado } \\
\text { ou } 1 \text { bes quadrado }\end{array}$ \\
Vários ladrilhos hexagonais & Largura modular: 1 bes ou 1 triens ou 2 unciae (polegadas) \\
\hline $\begin{array}{l}\text { Pequenas pedras e tijolos } \\
\text { para mosaico de pisos }\end{array}$ & $\begin{array}{l}\text { Espaço modular: } 1 \text { uncia cúbica ou } 1 \text { semiuncia cúbica ou } \\
1 \text { sificus (rocha) cúbica }\end{array}$
\end{tabular}

"Em uma casa tipicamente japonesa, a trama Ken - medida implantada na Idade Média - regia a estrutura e a sequencia aditiva, de espaço a espaço, das diferentes habitações" (MARQUES, 2009).

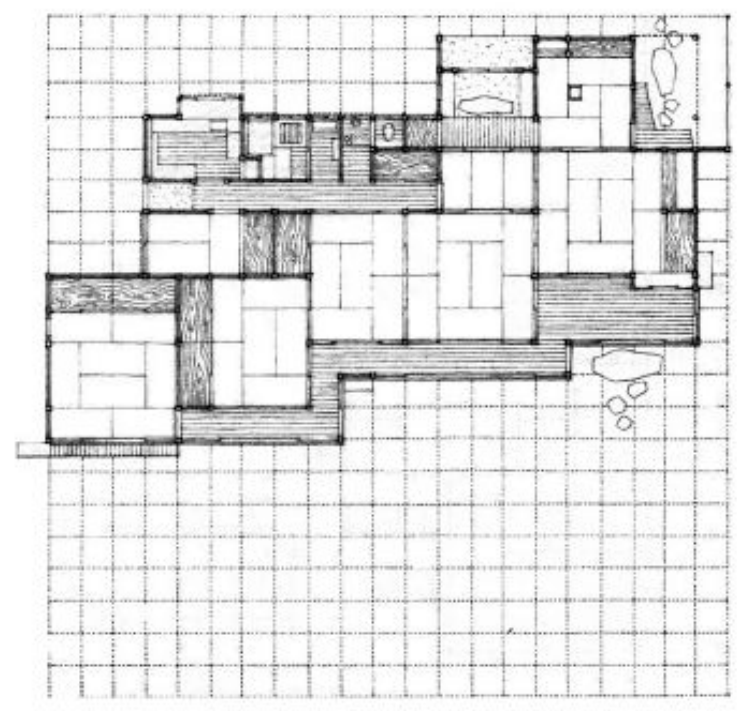

Figura 3.13 - Planta de residência típica japonesa (MARQUES, 2009 baseada em CHING, 2002). 
3.4 .2

\section{Modulação na alvenaria estrutural}

"Quando o processo construtivo é em alvenaria estrutural, a coordenação modular torna-se etapa imprescindivel de projeto. Os cuidados com relação à modulação devem ser tomados para garantir a racionalização da construção e permitir o alto índice de produtividade que este processo é capaz de atingir, além de reduzir a quantidade de ajustes e a quebra de blocos.

Uma das primeiras etapas do projeto estrutural consiste na modulação das paredes, baseada nas dimensões arquitetônicas e na definição do tipo de bloco adotado.

Os blocos modulares e submodulares devem atender às dimensões reais constatadas na ABNT (1994), NBR 6136, para blocos estruturais de concreto e ABNT (1992), NBR 7171 para os blocos cerâmicos, os quais se encontram divididos segundo sua largura padrão $(20$ ou $15 \mathrm{~cm})$ ", (MAMEDE, 2001).

As Tabelas 3.2 e 3.3 informam as dimensões dos blocos de concreto e cerâmicos conforme normas existentes no mercado.

Tabela 3.2 - Dimensões reais dos blocos modulares e submodulares de concreto segundo a NBR 6136.

\begin{tabular}{c|c|c|c|c|}
\hline \multirow{2}{*}{ Dimensão (cm) } & \multirow{2}{*}{ Designação } & \multicolumn{3}{|c|}{ Dimensōes coordenadas (mm) } \\
\cline { 3 - 5 } & & Largura & Altura & Comprimento \\
\hline \multirow{2}{*}{20} & \multirow{2}{*}{ M-20 } & 190 & 190 & 190 \\
\hline \multirow{2}{*}{15} & \multirow{2}{*}{ M-15 } & 190 & 190 & 390 \\
\hline & & 140 & 190 & 190 \\
\hline & & 140 & 190 & 390 \\
\hline
\end{tabular}

Tabela 3.3 - Dimensões reais dos blocos cerâmicos segundo a NBR 7171.

\begin{tabular}{|c|c|c|c|c|}
\hline \multirow{2}{*}{ Dimensão (cm) } & \multirow{2}{*}{ Designação } & \multicolumn{3}{|c|}{ Dimensōes coordenadas (mm) } \\
\cline { 3 - 5 } & & Largura & Altura & Comprimento \\
\hline \multirow{3}{*}{20} & \multirow{3}{*}{ M-20 } & 190 & 190 & 190 \\
\hline \multirow{3}{*}{15} & 190 & 190 & 240 \\
\hline \multirow{3}{*}{15} & 190 & 190 & 290 \\
\hline & \multirow{3}{*}{ M-15 } & 190 & 190 & 390 \\
\cline { 3 - 5 } & & 140 & 190 & 240 \\
\hline & & 140 & 190 & 390 \\
\hline
\end{tabular}

Segundo MAMEDE (2001), após pesquisa realizada com os blocos fornecidos no mercado, existe a necessidade de atualização da norma brasileira 
em relação aos aspectos dimensionais dos blocos, pois o mercado consumidor exige produtos que facilitem e harmonizem o processo de modulação.

"O espaço modular compreende a associação do componente com a sua junta (normalmente a argamassa). O mau preenchimento da junta horizontal, segundo FRANCO (1987), pode representar uma diminuição de 30\% na resistência a compressão. Baseado nesta informação pode-se comprovar que a modulação na alvenaria deixa de ter apenas caráter dimensional e passa a ter também implicações estruturais.

A incompatibilidade entre as dimensões dos componentes da edificação, muitas vezes, resulta em ajustes dimensionais de grandes espessuras e frequentemente nos projetos não são especificadas soluções para o preenchimento destes ajustes, que acabam por serem executados de improviso na obra.

Algumas indústrias fabricantes de blocos já fornecem no mercado os elementos de ajustes denominando-os de blocos complementares.

A modulação da alvenaria estrutural é o acerto das dimensões em planta e do pé direito da edificação, em função das dimensões dos blocos, de modo a se evitar cortes ou ajustes na execução das paredes" (MAMEDE, 2001).

\subsection{3 \\ Vantagens e desvantagens da coordenação modular}

"De uma maneira geral, as principais vantagens da coordenação modular são:

a) Simplificação na elaboração do projeto;

b) Normalização dos componentes da construção;

c) Otimização das dimensões com redução do número de formato de componentes construtivos;

d) Redução de problemas de interface entre componentes $e$ subsistemas;

e) Padronização dos detalhes e precisão dimensional;

f) Racionalização e simplificação na execução da obra devido a facilidade de montagem;

g) Redução de quebras de materiais, evitando-se perdas na construção." (MARQUES, 2009).

Segundo MARQUES (2009), as principais desvantagens são:

a) necessidade de se ter componentes sem variação dimensional e qualitativa no mercado, padronizados;

b) necessidade de investimento em preparo e treinamento de mão de obra. 


\section{5}

\section{Projetos em alvenaria estrutural}

Os projetos em Alvenaria Estrutural apresentam um nível de detalhamento mais aprimorado. Todas as etapas devem estar devidamente compatibilizadas (principalmente instalações em geral), e o ideal é que se tenha um projeto complementar de alvenaria modulada que orienta sobre a paginação dos blocos de forma que se tenha a menor quantidade possível de perdas.

É na fase de projeto que as decisões trarão maior repercussão nos custos, na velocidade de execução e na qualidade dos empreendimentos. Toda modificação realizada nessa fase terá um custo muito inferior se realizado em fases posteriores, por isso a importância de um tempo determinado para o correto desenvolvimento e compatibilização dos projetos. Alguns fatores listados a seguir são fundamentais para um projeto racionalizado.

1) Sistema de coordenação das diversas disciplinas do projeto propiciando integração entre as equipes de projetistas.

2) Determinação de um cronograma de elaboração de projeto, onde as disciplinas devem estar conectadas para a correta interação da compatibilização.

3) Padronização e simplificação das soluções como, por exemplo uma predefinição de pés direito.

4) Detalhamento completo dos projetos para evitar dúvidas e erros de execução durante a obra.

Esse projeto levará em conta as dimensões dos blocos para o acerto das cotas em planta e pés direitos do projeto arquitetônico.

O processo de modulação tem início com a escolha das dimensões dos blocos, evitando o uso de blocos especiais.

O ideal é que os projetos arquitetônicos já considerem dimensões modulares para que o ajuste final seja o menor possível. O arquiteto deve estar atento à modulação.

A Figura 3.14 a seguir mostra uma planta baixa desenvolvida pelo arquiteto sem a preocupação com a modulação. 


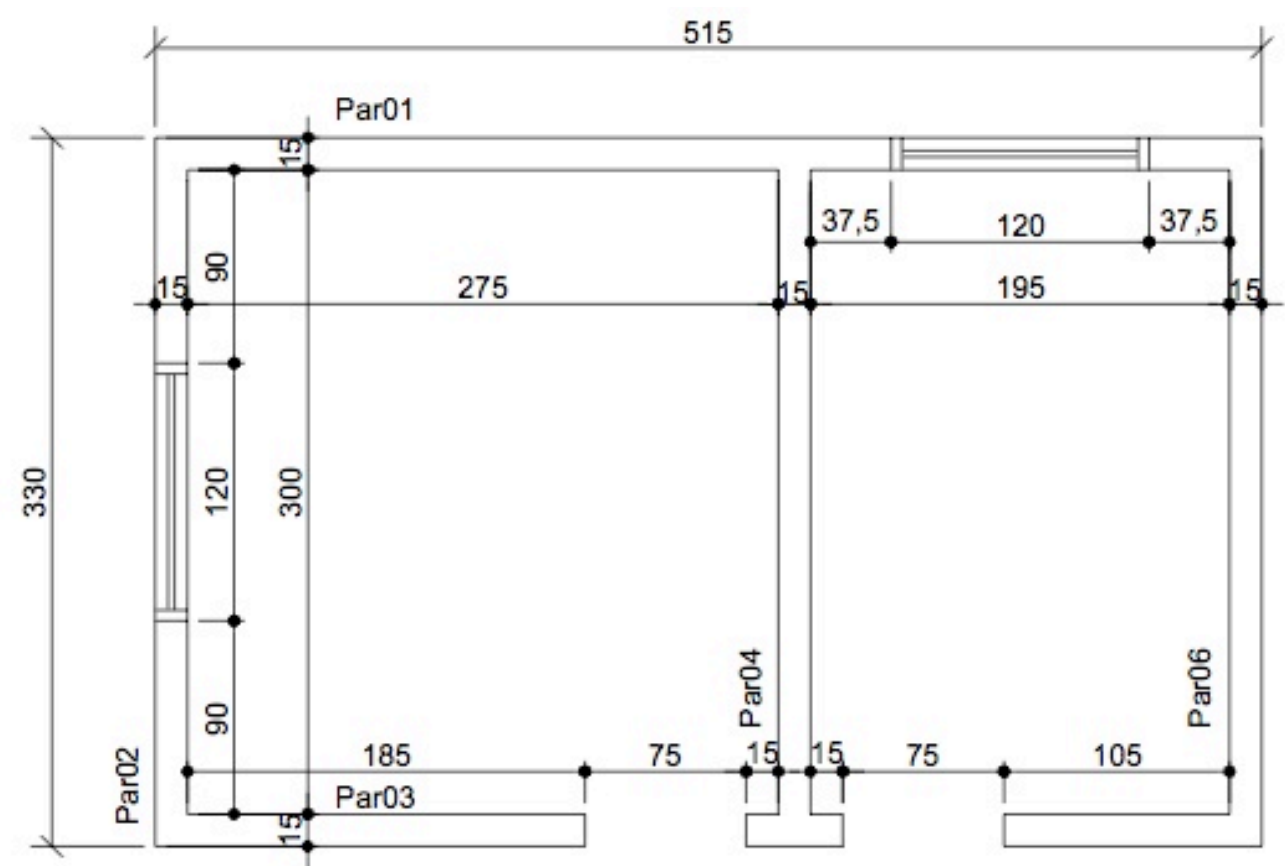

Figura 3.14 - Planta de arquitetura (MAMEDE, 2001).

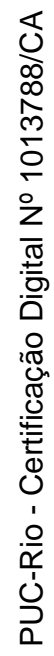

Na Figura 3.15 está a planta de $1^{\mathrm{a}}$ fiada levando em consideração a modulação para a planta de arquitetura apresentada na Figura 3.14.

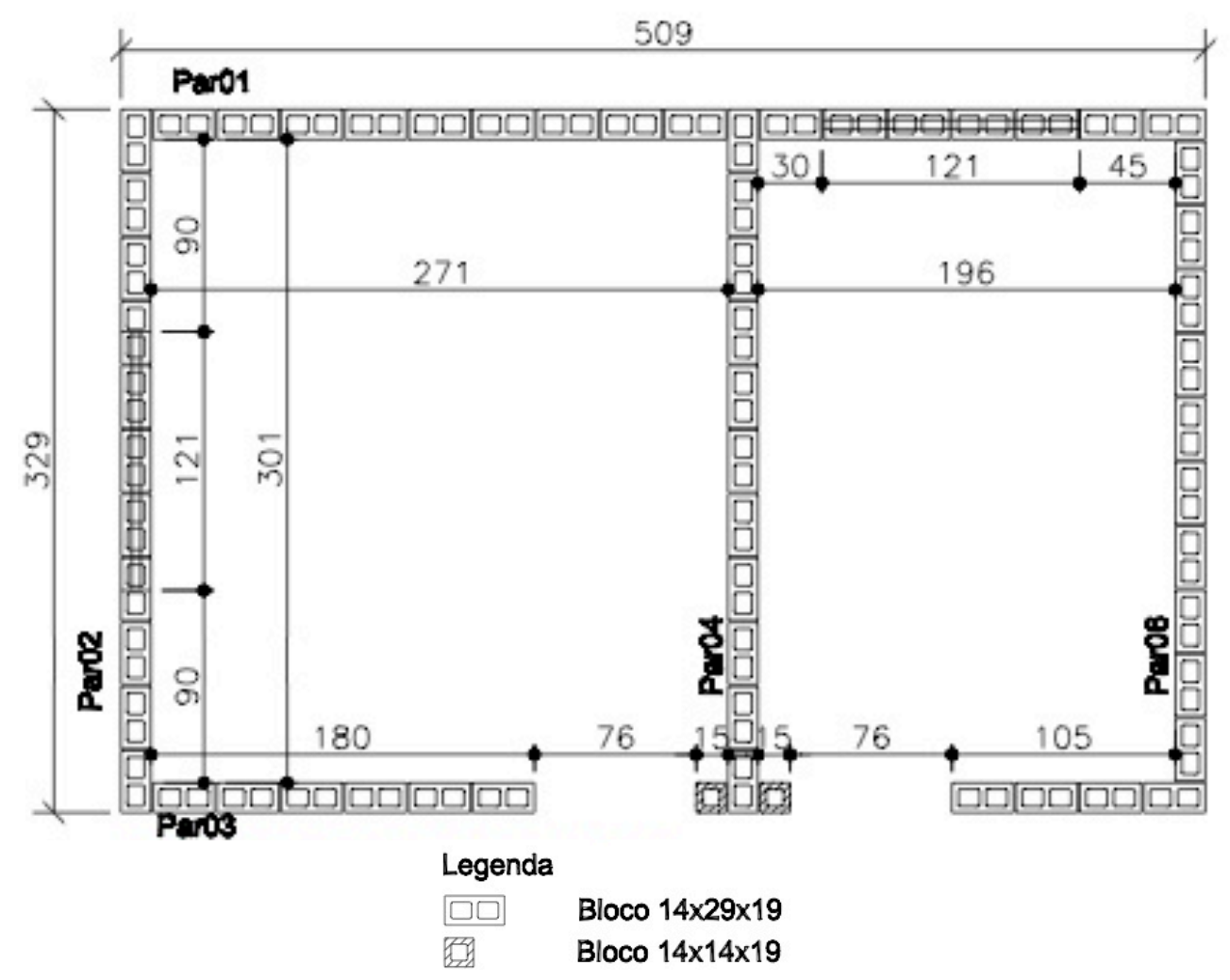

Figura 3.15 - Planta de modulação M-15 da 1a fiada com blocos BL-15 (MAMEDE, 2001). 
A Figura 3.15 adequa a planta inicialmente projetada na arquitetura para uma solução modular. Pode-se perceber ganhos e perdas de cota o que deve ser avaliado junto ao arquiteto, já que normalmente se estuda um layout mínimo de mobiliário e circulações para a utilização dos cômodos conforme norma de desempenho.

Os vãos também têm suas cotas alteradas e devem ser avaliados quanto as dimensões mínimas exigidas legalmente e por norma para iluminação e ventilação, bem como o fornecimento de esquadrias que não fujam de formatos padrão de melhor custo benefício para a obra.

A partir do exemplo, verifica-se a necessidade de adequação das dimensões que anteriormente não eram modulares.

Porém, se é desejável manter as medidas mais próximas do projetado na arquitetura, pode-se fazer uso de blocos especiais. A eficiência não será a melhor possível, pois irão encarecer o custo da obra e aumentar a quantidade de componentes utilizados. Mas em determinados casos seu uso torna-se viável.

A Figura 3.16 a seguir ilustra essa solução.

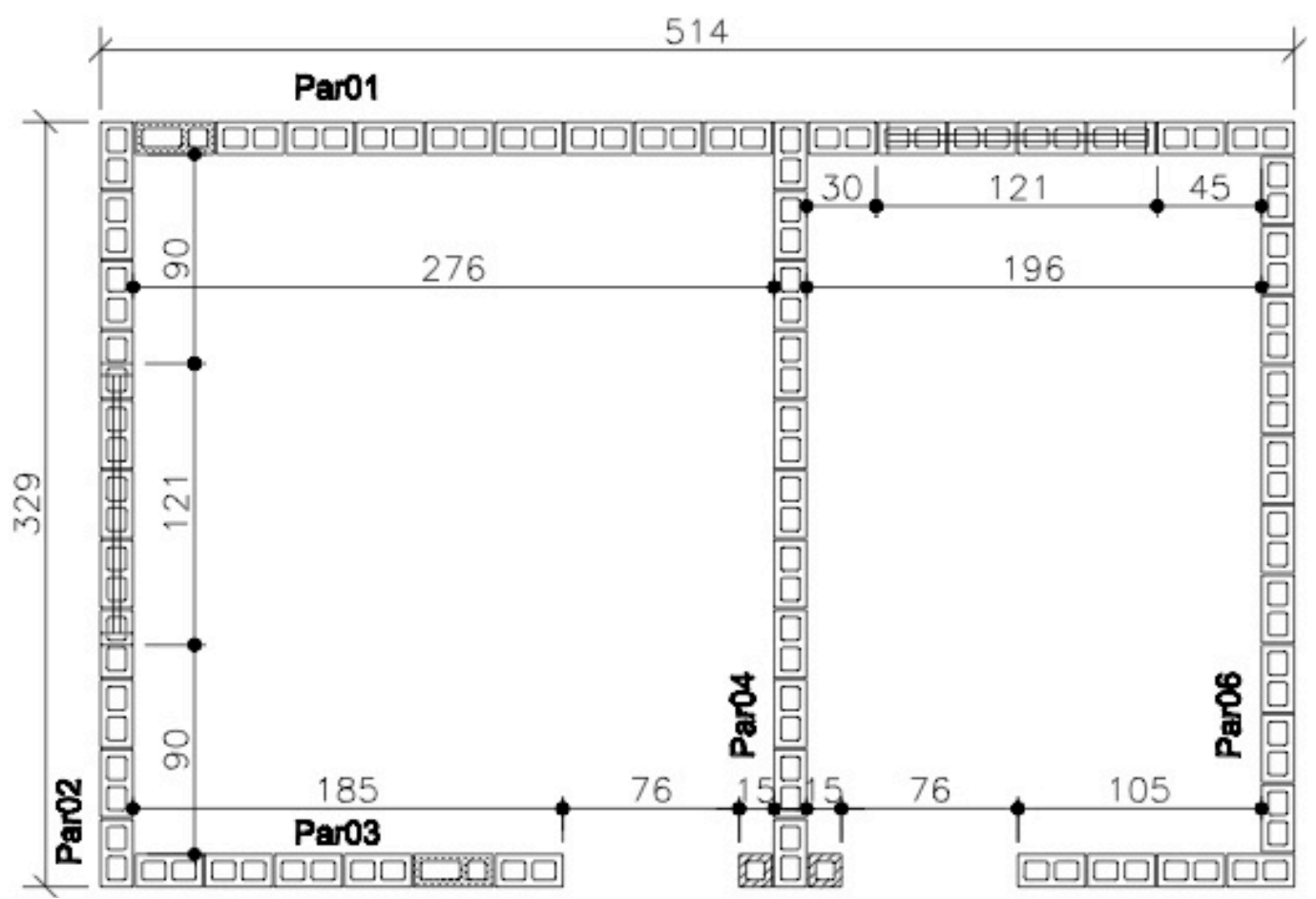

Legenda

Figura 3.16 - Planta de modulação M-15 da 1a fiada com blocos BL-15 e emprego de bloco especial de $35 \mathrm{~cm}$ de comprimento modular (MAMEDE, 2001). 
Também deve ser levado em consideração o pé-direito dos pavimentos tipo das edificações que seguem o somatório das alturas dos blocos.

As construtoras costumam adotar padrões mais eficientes que em alguns casos, podem limitar o estudo de massa e viabilidade de um empreendimento não permitindo o pleno aproveitamento construtivo do lote em função da legislação local.

Outro aspecto importante para o projeto são as amarrações entre duas paredes que se encontram.

A amarração direta é o entrosamento alternado de fiadas, que permite a interação de paredes por existirem caminhos alternativos para o fluxo de cargas, que começa em uma parede e se espalha por paredes adjacentes. Tal fato pode ser resumido em um conceito: a tendência de uniformização de tensões que ocorre ao longo da altura do edifício. Essa tendência é altamente benéfica ao comportamento estrutural das paredes, pois significa que as mais carregadas servem-se das menos solicitadas para aliviarem os seus excessos.

A amarração pode ser efetuada basicamente de duas maneiras:

- amarração direta: obtida por meio do intertravamento dos blocos, havendo interposição entre os blocos de $50 \%$ na parede interceptada (Figura 3.17);

- amarração indireta: obtida por meio da colocação de armaduras nas juntas de argamassa, com ângulo de $90^{\circ}$, podendo ser efetuada por meio de barras de aço dobradas, armadura industrializada em forma de treliças ou grampos, chapas ou telas metálicas de resistência comprovada (Figura 3.18). (CORRÊA e RAMALHO, 1994). 


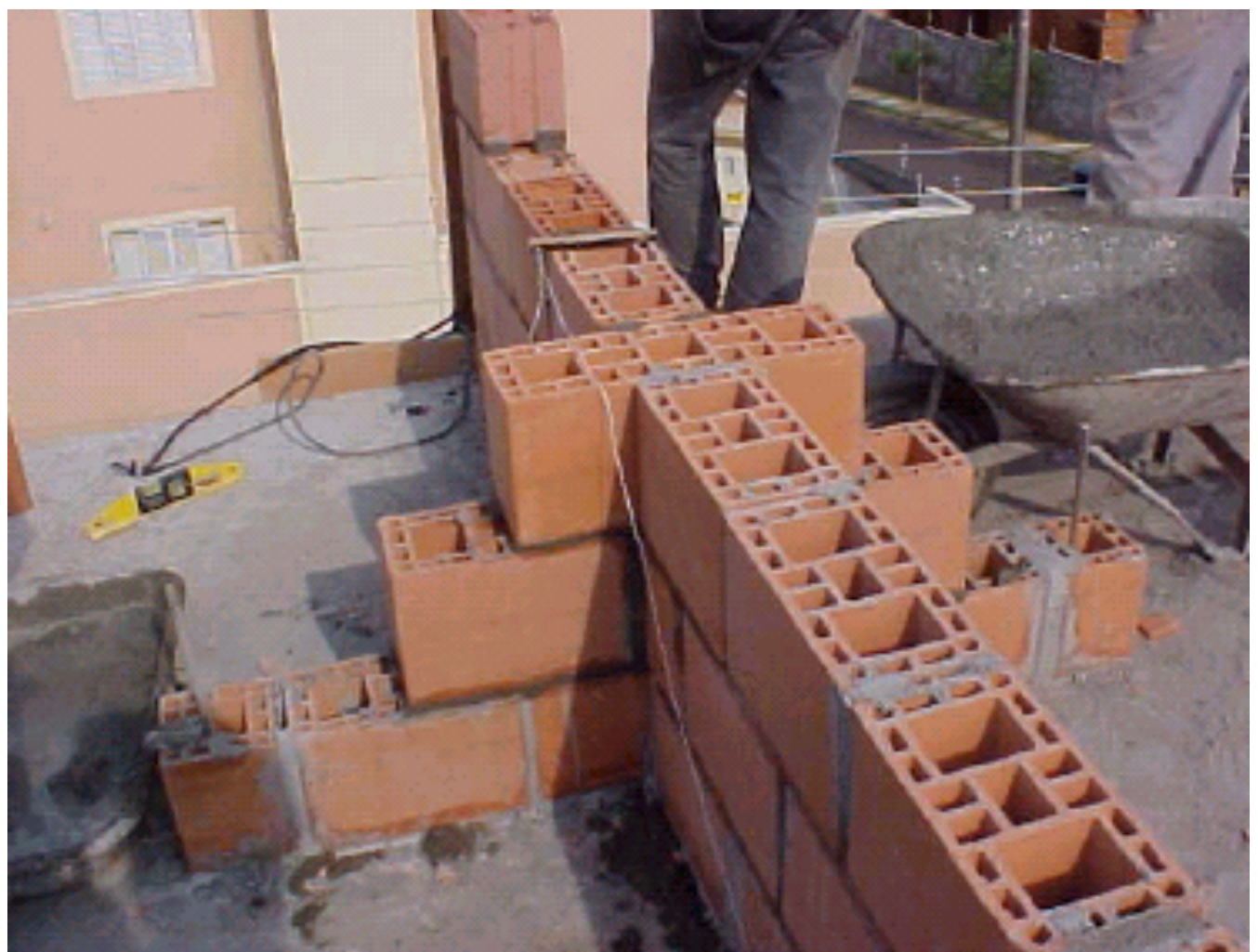

Figura 3.17 - Exemplo de amarração direta (FURLAN JUNIOR, 2004).

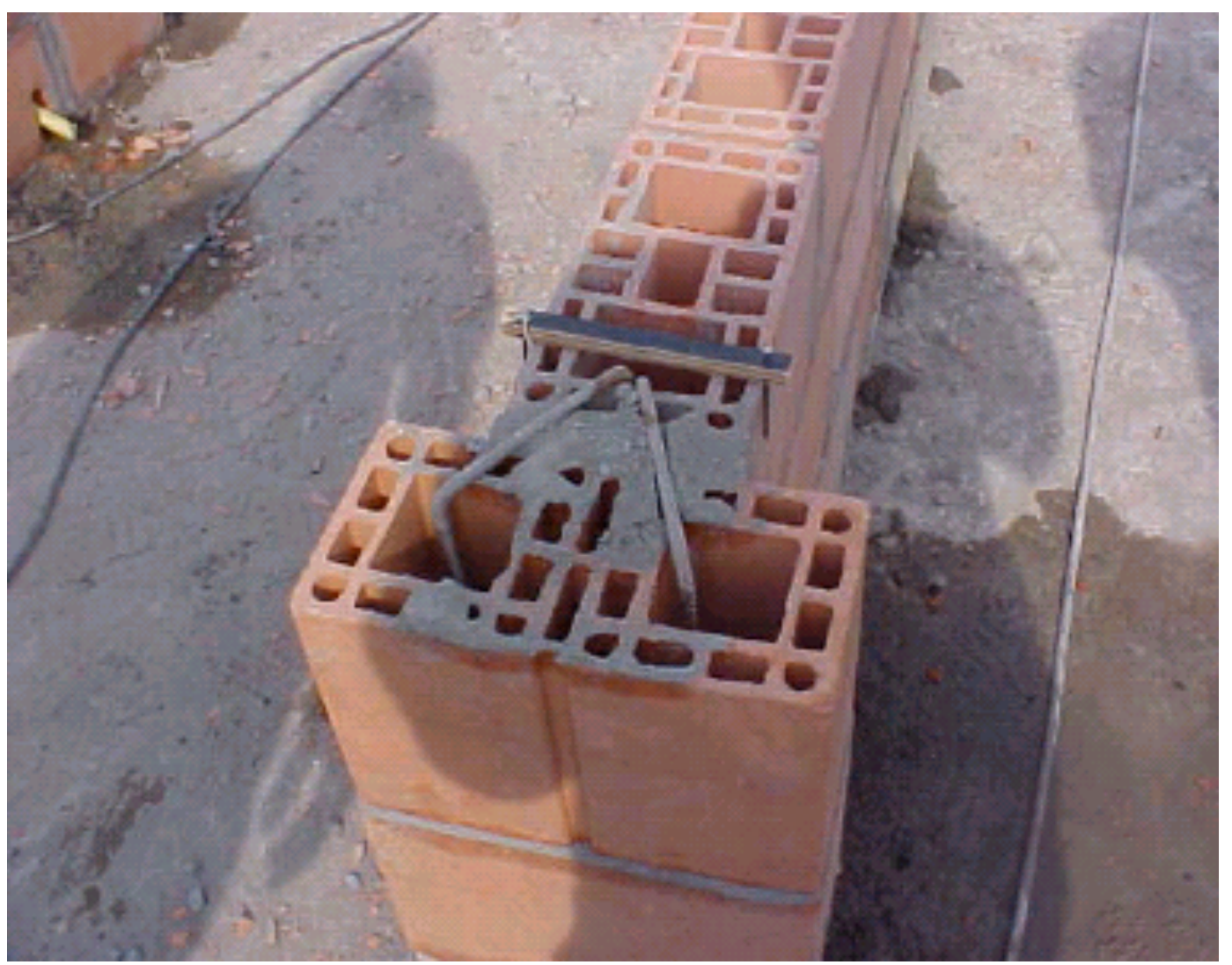

Figura 3.18 - Exemplo de amarração indireta (FURLAN JUNIOR, 2004). 
Com relação às instalações elétricas é adequado que as alturas dos pontos (baixos, médios e altos) sejam padronizadas. Assim, são definidas as fiadas para a instalação das caixinhas.

Para as instalações hidráulicas e de gás, o ideal é que fiquem aparentes e não embutidas para não interferirem com as modulações.

Todos esses aspectos determinam um projeto menos flexível. Para o cliente final pode não ser o produto ideal, uma vez que não há tantas manobras que possibilite diferentes opções de planta.

Outro aspecto negativo do ponto de vista do cliente são as instalações aparentes, o que é mais uma questão cultural. À medida que o método se difunde, e que se defende que as instalações aparentes são mais adequadas no que diz respeito à futura manutenção, a tendência é que o cliente admita e aceite a solução.

\subsection{1 \\ Eficiência desde o projeto}

A determinação do sistema construtivo, normalmente vem desde o estudo de viabilidade do empreendimento. Nesse estudo já são contempladas as principais características e limitações como, por exemplo, o padrão e tipologia do empreendimento, o número máximo de pavimentos, pés direitos entre lajes, dimensão dos ambientes para disposição das paredes, necessidade de vagas para previsão de estacionamentos cobertos para análise de soluções mistas, etc.

Com essas informações o arquiteto poderá projetar o estudo que será orçado e validado caso passe nos cálculos de viabilidade do empreendimento.

Para um projeto mais eficiente, deve-se levar em consideração a adequação e compatibilização de todas as disciplinas desde o anteprojeto, etapa posterior ao estudo de viabilidade que irá determinar e reunir mais informações para o desenvolvimento do projeto executivo.

A construtora que determina a necessidade de se oferecer durante a obra opções de plantas para os futuros clientes. Nesse caso, isso também será determinante para que o projeto estrutural possa ser dimensionado considerando 
algumas paredes não estruturais que possam ser removidas ou deslocadas pelo cliente posteriormente.

Também são determinadas pela construtora as necessidades de áreas comuns, quais ambientes devem ser previstos e quais as áreas estimadas. Assim a estrutura terá que verificar se haverá a necessidade de solução mista com vigamento para o deslocamento de paredes.

Em muitos casos, a disposição de vagas apenas nos térreos não suporta a quantidade mínima de vagas exigidas para a quantidade de apartamentos projetada e viabilizada. Quando isso ocorre, se faz necessário pavimento extra de subsolo e soluções de pilotis dos térreos dos blocos para a disposição dessas vagas. Com essa necessidade, os embasamentos também sofrem solução mista com vigamentos específicos.

Ainda na determinação do partido arquitetônico e para verificação do dimensionamento da estrutura, deve ser definido se o empreendimento terá unidades de cobertura com previsão de piscina que gera uma carga diferenciada nos últimos pavimentos e também requer solução mista para a estrutura capaz de suportar essa solicitação.

Também na concepção, devem ser definidas as dimensões aproximadas das varandas e se as mesmas podem ficar embutidas ou se deverão ficar projetadas em balanço. Soluções embutidas barateiam o processo e soluções projetadas exigem solução mista com vigamentos.

As soluções mencionadas acima podem encarecer o projeto, mas devem ser validadas pela construtora dependendo do padrão e da localização do empreendimento em face de concorrência próxima e a legislação vigente.

Com todas essas determinações definidas, o primeiro passo a ser dado é a contratação de um coordenador que irá gerenciar toda a equipe. Nessa primeira etapa são analisadas as principais interferências entre as diferentes disciplinas como, por exemplo, a análise da passagem de tubulações de instalações com as necessidades de furações na estrutura para a passagem das mesmas. Isso deve ser estudado preliminarmente para que a estrutura tenha condições de determinar as paredes estruturais e as paredes não estruturais.

Para que o projeto seja o mais racional possível, é aconselhável a contratação de um projetista de alvenaria modulada que auxiliará a estrutura, a 
arquitetura e as instalações em soluções que minimizem a necessidade de elementos de ajustes ou blocos complementares.

A alvenaria modulada determinará toda a modulação e especificação dos blocos, que podem ser de concreto ou cerâmico, compatibilizando-os com a passagem das instalações e indicando as alturas dos pontos nas paredes. Normalmente eles fornecem todas as vistas de todas as paredes do projeto o que facilita a execução da obra e a própria compatibilização dos projetos.

É nesse projeto que a obra terá as informações de todos os elementos da alvenaria (blocos, juntas, vergas, armações e pontos de grauteamento) e de pontos de hidráulica e elétrica que interferem na execução da mesma.

Nas Figuras 3.19 e 3.20 são mostrados exemplos de plantas, vistas e legendas desse tipo de projeto.

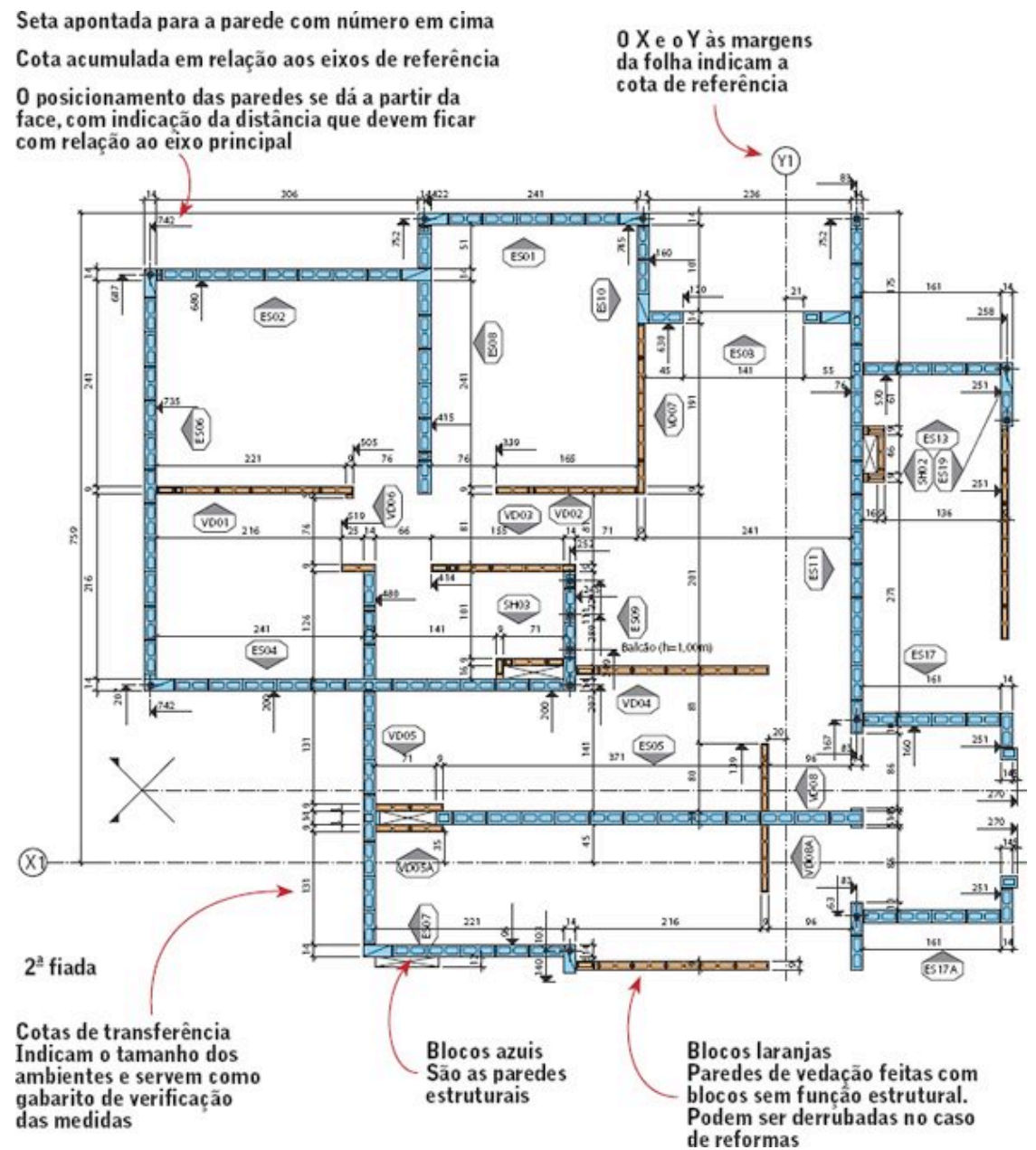

Figura 3.19 - Exemplo de planta e legenda de projeto de alvenaria com modulação da 2a fiada; http://www.equipedeobra.com.br/construcao-reforma/59/artigo284540-1.asp, visitado em: 19/05/2013. 


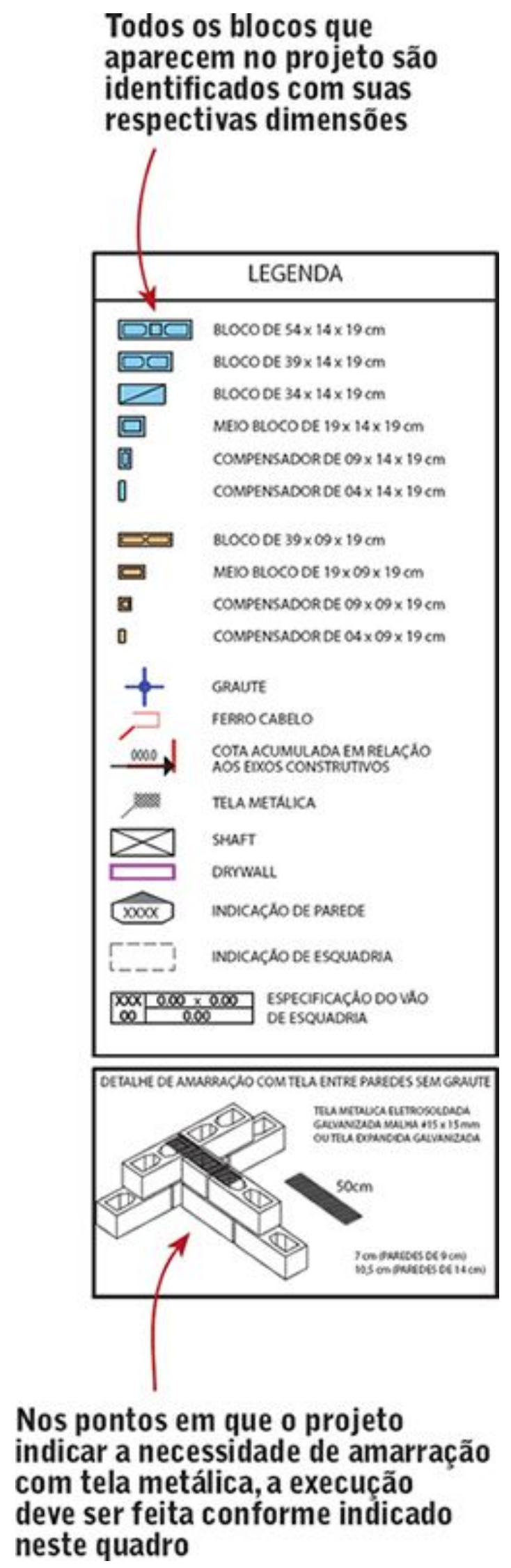

Figura 3.19 - Continuação. 

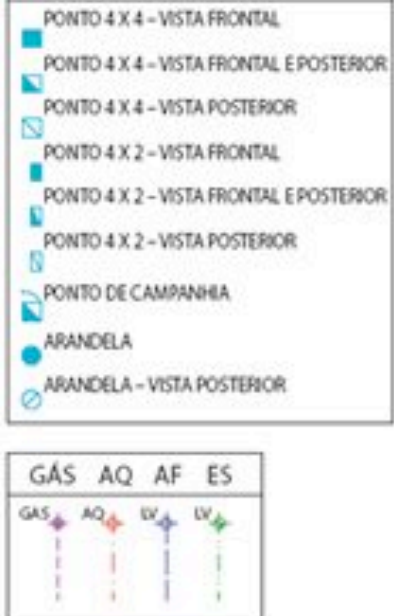

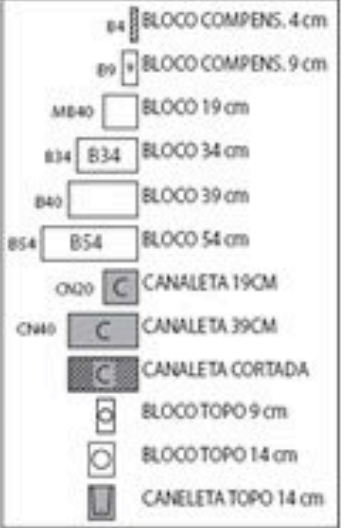

Blocos tipo canaleta. Contam com barra de aço para reforço

Este projeto mostra todos os detalhes sobre como a parede deve ser montada, incluindo o posicionamento de cada bloco, dos pontos de elétrica e das telas de amarração

Telas para amarração da alvenaria ao longo de sua altura

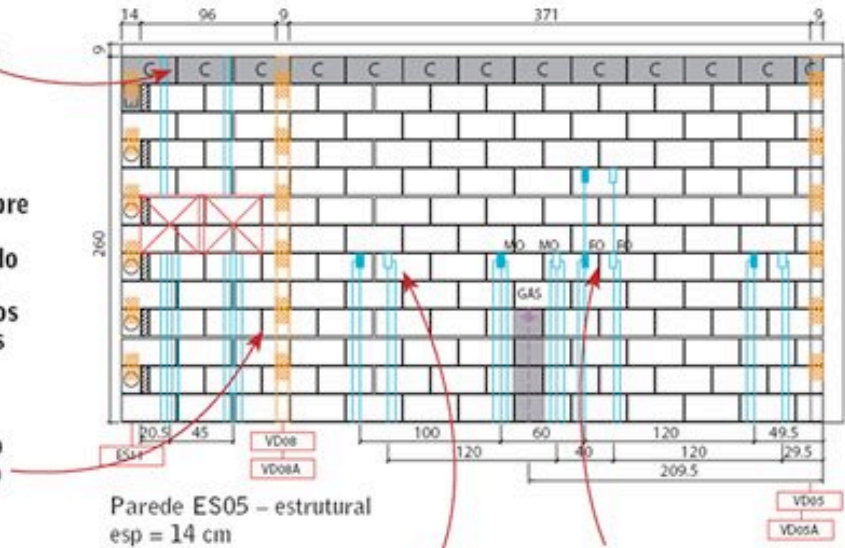

As caixas de luz vazadas estão voltadas para a outra face da parede. As preenchidas em preto

Caixas de luz e passagens de eletrodutos são representadas nesta planta, indicando o local
exato de onde devem ficar

Figura 3.20 - Exemplo de vista de projeto de alvenaria modulada;

http://www.equipedeobra.com.br/construcao-reforma/59/artigo284540-1.asp, visitado em: 19/05/2013.

\section{6}

\section{Execução da obra em alvenaria estrutural e economias}

Uma obra em alvenaria estrutural tem grande potencial de ser mais econômica em função da unidade estrutural, e em função do sistema adotado.

Contribui para essa economia a unidade de materiais na obra, a modulação do projeto e a dinâmica racional de execução do processo.

A execução começa com o assentamento da primeira fiada. Essa deve ser executada com perfeição, pois servirá de marcação para toda a parede. Para uma melhor aderência dos blocos, é importante que a base de assentamento esteja umedecida. 
O assentamento é iniciado pelos cantos das paredes espalhando a argamassa. Nessa deve ser feito um sulco proporcional a largura dos blocos para facilitar o assentamento (Figura 3.21).
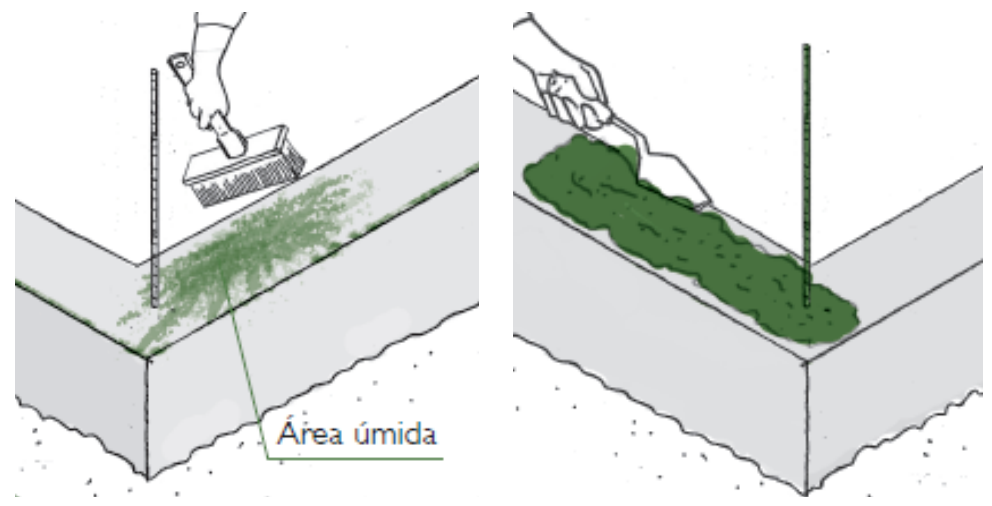

Figura 3.21 - Assentamento primeira fiada;

http://www.maosaobra.org.br/fasciculos/fasciculo-alvenaria/alvenaria-estrutural-comblocos-de-concreto/execucao-passo-a-passo-levantamento-da-alvenaria/, visitado em: 26/05/2013.

É importante executar as duas primeiras fiadas com argamassa impermeabilizante para evitar infiltrações e consequentes umidades das paredes.

Os blocos são encaixados nas barras de aço em espera. A argamassa entre as fiadas de blocos ou juntas deve ter $1 \mathrm{~cm}$ de espessura (Figura 3.22) .

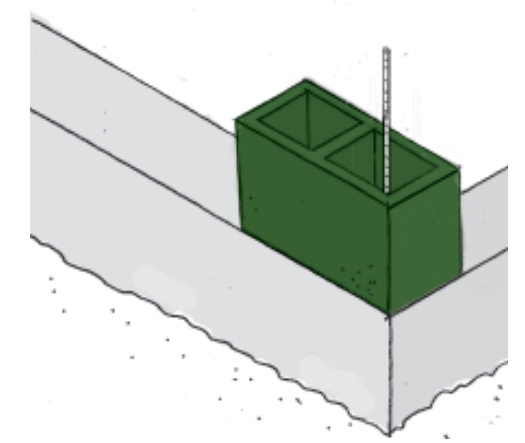

Figura 3.22 - Encaixe dos blocos nas barras de aço;

http://www.maosaobra.org.br/fasciculos/fasciculo-alvenaria/alvenaria-estrutural-comblocos-de-concreto/execucao-passo-a-passo-levantamento-da-alvenaria/, visitado em: 26/05/2013.

Para verificação do alinhamento entre os blocos da mesma fiada, é utilizado um fio de náilon amarrado e esticado a partir das extremidades (Figura $3.23)$. 


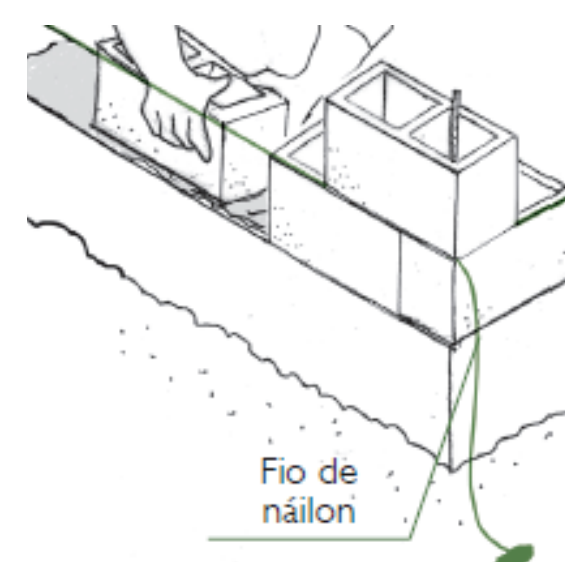

Figura 3.23 - Verificação do alinhamento entre os blocos da mesma fiada;

http://www.maosaobra.org.br/fasciculos/fasciculo-alvenaria/alvenaria-estrutural-comblocos-de-concreto/execucao-passo-a-passo-levantamento-da-alvenaria/, visitado em: 26/05/2013.

As tubulações elétricas e de telefonia passam por dentro dos blocos que devem ser furados para que as caixas elétricas sejam posicionadas conforme indicado no projeto de alvenaria modulada. Com base nesses projetos, os blocos que receberão as caixas elétricas devem ser previamente preparados e devem estar prontos para o assentamento deixando a etapa mais produtiva (Figura 3.24).

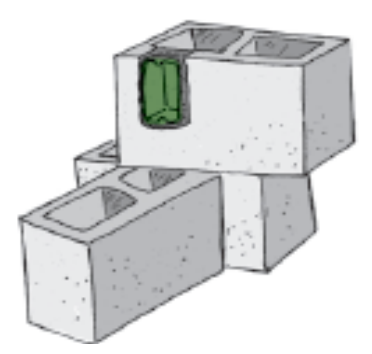

Figura 3.24 - Preparação blocos com pontos de instalação;

http://www.maosaobra.org.br/fasciculos/fasciculo-alvenaria/alvenaria-estrutural-comblocos-de-concreto/execucao-passo-a-passo-levantamento-da-alvenaria/, visitado em: 26/05/2013.

Também é importante que sejam utilizadas as ferramentas corretas para a aplicação da argamassa para se evitar desperdícios (Figura 3.25). 


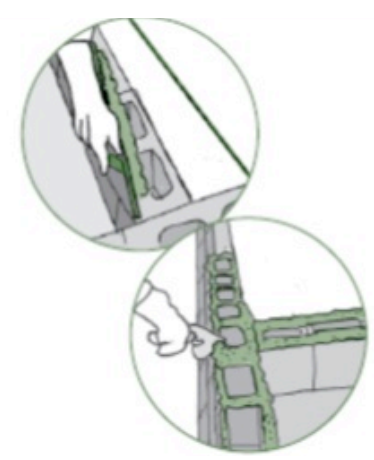

Figura 3.25 - Utilização de ferramentas corretas para aplicação de argamassa;

http://www.maosaobra.org.br/fasciculos/fasciculo-alvenaria/alvenaria-estrutural-comblocos-de-concreto/execucao-passo-a-passo-levantamento-da-alvenaria/, visitado em: 26/05/2013.

O assentamento das demais fiadas é feito com o posicionamento da régua de marcação nas extremidades da primeira fiada (Figura 3.26). Cada parede deve ter sua construção iniciada pelos cantos com o assentamento dos blocos com junta amarrada.

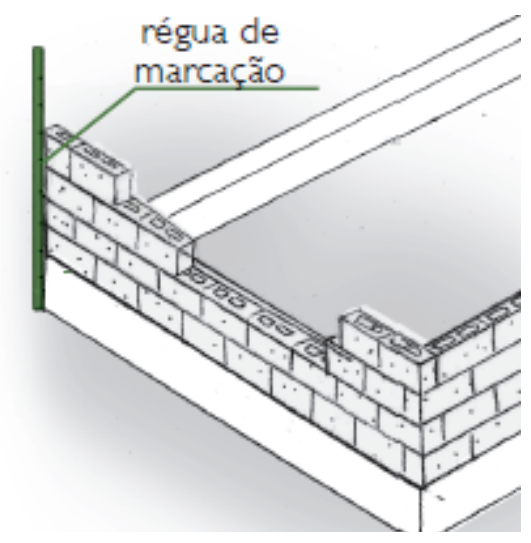

Figura 3.26 - Marcação das extremidades da alvenaria;

http://www.maosaobra.org.br/fasciculos/fasciculo-alvenaria/alvenaria-estrutural-comblocos-de-concreto/execucao-passo-a-passo-levantamento-da-alvenaria/, visitado em: 26/05/2013.

$\mathrm{Na}$ execução das demais fiadas das paredes deve-se seguir a linha de referência para garantir o alinhamento e verificar o nível e o prumo (Figura 3.27). 


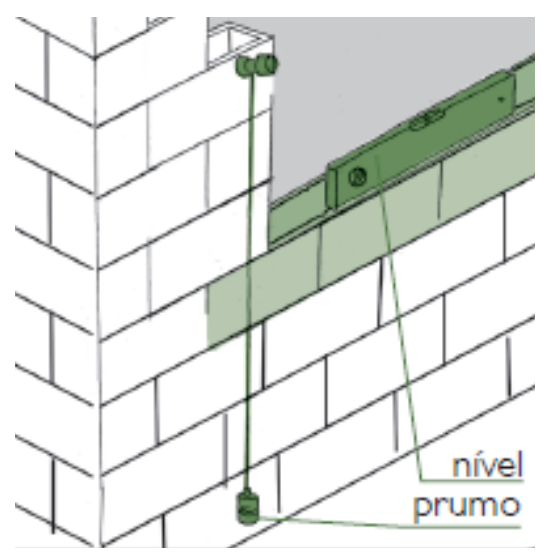

Figura 3.27 - Verificação do alinhamento, nível e prumo da alvenaria;

http://www.maosaobra.org.br/fasciculos/fasciculo-alvenaria/alvenaria-estrutural-comblocos-de-concreto/execucao-passo-a-passo-levantamento-da-alvenaria/, visitado em: 26/05/2013.

$\mathrm{O}$ excesso de argamassa deve ser eliminado à medida em que os blocos forem assentados para otimizar o tempo de execução.

Para uma obra mais limpa e com menos resíduos, os conduítes e as tubulações hidráulicas devem passar por dentro dos blocos até atingirem as respectivas saídas: caixas de interruptor, tomadas e pontos de água. Assim, as paredes não precisam ser cortadas para o posicionamento das instalações (Figura $3.28)$.

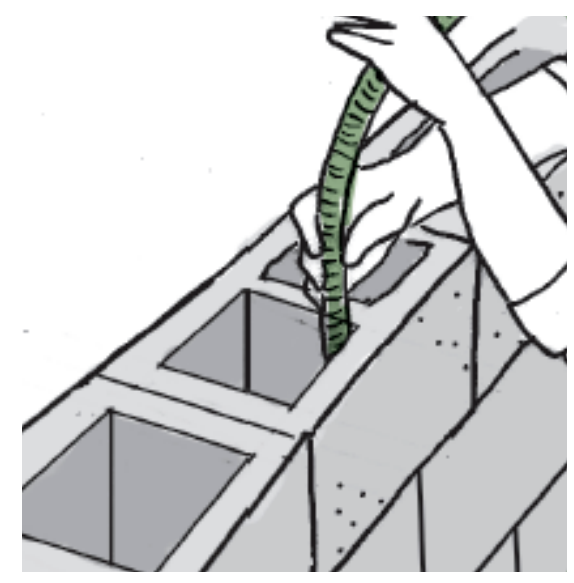

Figura 3.28 - Passagem das tubulações elétricas e hidráulicas na alvenaria;

http://www.maosaobra.org.br/fasciculos/fasciculo-alvenaria/alvenaria-estrutural-comblocos-de-concreto/execucao-passo-a-passo-levantamento-da-alvenaria/, visitado em: 26/05/2013.

O nível e o prumo devem ser conferidos constantemente. Paredes desalinhadas podem levar ao colapso da estrutura (Figura 3.29). 


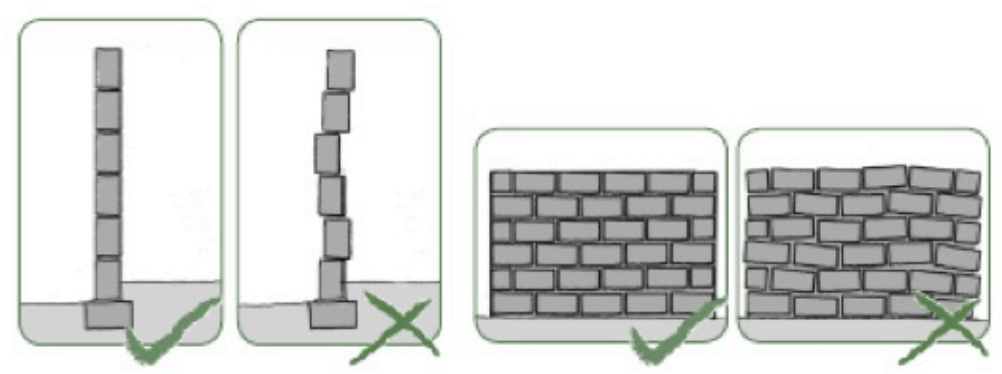

Figura 3.29 - Nível e prumo das paredes;

http://www.maosaobra.org.br/fasciculos/fasciculo-alvenaria/alvenaria-estrutural-comblocos-de-concreto/execucao-passo-a-passo-levantamento-da-alvenaria/, visitado em: 26/05/2013.

Para a intersecção perpendicular entre as paredes externas e internas devem ser utilizados ferros em "L" a cada duas fiadas. É importante verificar se a sobreposição entre a emenda das barras tanto na vertical como na horizontal estão corretas (Figura 3.30).
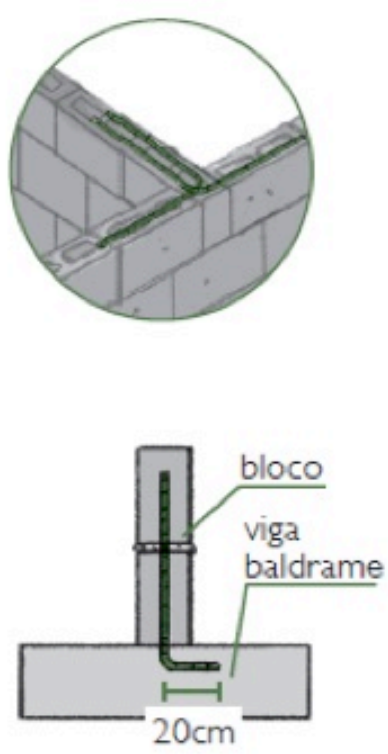

Figura 3.30 - Intersecção perpendicular entre as paredes;

http://www.maosaobra.org.br/fasciculos/fasciculo-alvenaria/alvenaria-estrutural-comblocos-de-concreto/execucao-passo-a-passo-levantamento-da-alvenaria/, visitado em: 26/05/2013.

Para a execução dos vãos (portas e janelas), devem ser instaladas vergas e contra-vergas com blocos canaleta, barra e preenchimento com graute. Tanto a 
verga como a contra-verga devem ter um traspasse de no mínimo $20 \mathrm{~cm}$ com relação as paredes (Figura 3.31).

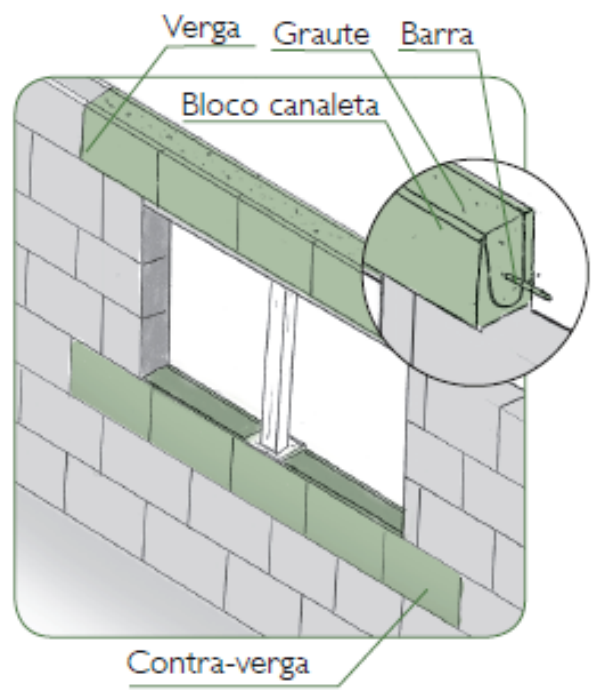

Figura 3.31 - Execução de vãos: janelas e portas;

http://www.maosaobra.org.br/fasciculos/fasciculo-alvenaria/alvenaria-estrutural-comblocos-de-concreto/execucao-passo-a-passo-levantamento-da-alvenaria/, visitado em: 26/05/2013.

A alvenaria deve ser preenchida verticalmente com graute nas extremidades e cantos formando pilaretes armados. Internamente, os blocos das extremidades devem estar completamente livres de resíduos para a continuidade do grauteamento ao longo da parede e a melhor aderência ao bloco. A limpeza é realizada com uma barra de aço que eliminará as rebarbas das juntas (Figura 3.32). Para a remoção dos resíduos faz-se um furo na lateral do bloco da primeira fiada.

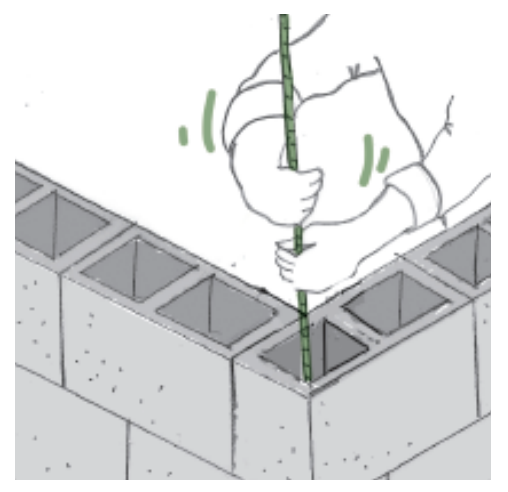

Figura 3.32 - Reforço vertical nas extremidades;

http://www.maosaobra.org.br/fasciculos/fasciculo-alvenaria/alvenaria-estrutural-comblocos-de-concreto/execucao-passo-a-passo-levantamento-da-alvenaria/, visitado em: 26/05/2013. 
Para o fechamento vertical da alvenaria, ao final da última fiada de blocos comuns, deve ser executada a cinta de amarração com blocos tipo canaleta, barra e preenchimento com graute. Devem ser deixadas esperas de barra de aço para a fixação da laje. A cinta deve ser executada em toda a última fiada e em todas as paredes, inclusive as de vedação, de forma contínua, melhorando a rigidez da construção com o aumento da amarração. Também se deve ter atenção ao traspasse entre as barras nos cantos (Figura 3.33).

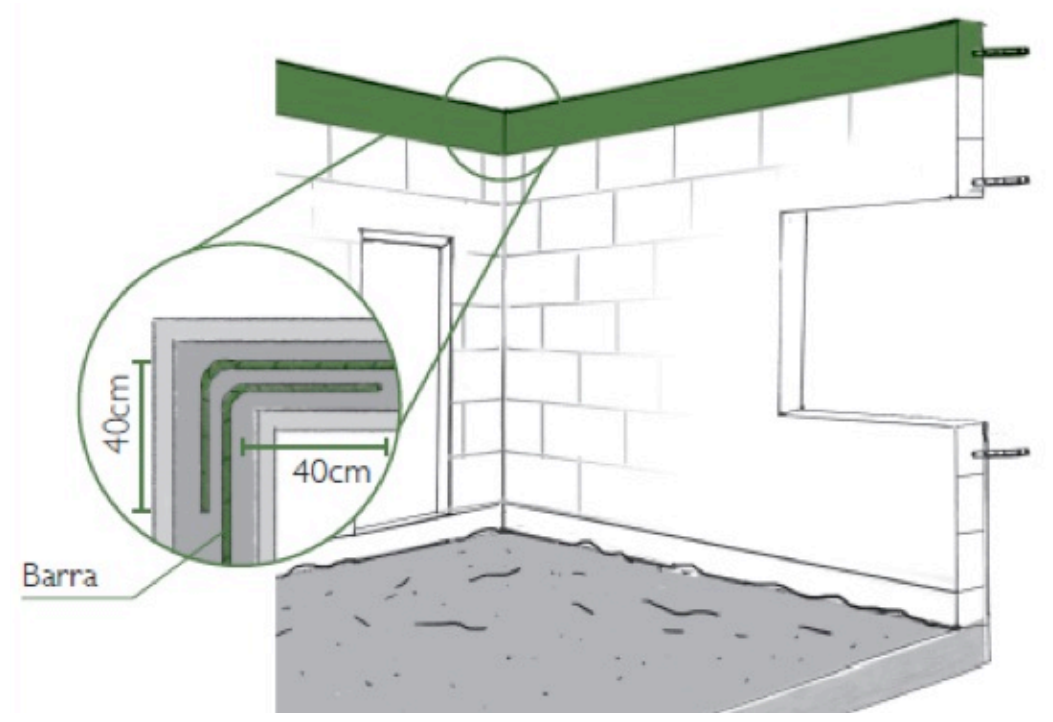

Figura 3.33 - Execução da cinta; http://www.maosaobra.org.br/fasciculos/fasciculoalvenaria/alvenaria-estrutural-com-blocos-de-concreto/execucao-passo-a-passolevantamento-da-alvenaria/, visitado em: 26/05/2013.

Seguindo todo o processo devidamente, se contribui para uma obra mais limpa e com menos desperdício.

Em muitos casos é possível instalar uma pequena usina para reciclagem do material residual que poderá ser utilizado como contrapiso.

Em empreendimentos em alvenaria estrutural, consta no manual do proprietário a informação de que as paredes estruturais não podem ser removidas, nem alteradas para a passagem de tubulações. $O$ cliente também recebe uma planta indicando as paredes estruturais. 


\section{4}

\section{Legislação}

\section{1}

\section{Limitações da Legislação}

Algumas normas e leis estabelecem as diretrizes para a utilização da alvenaria estrutural. Em algumas situações pode ser um limitador, já que especifica regras para a elaboração dos projetos, quantidade máxima de pavimentos, critérios rígidos de resistência para os materiais componentes do sistema, padrões e controles para a execução da obra, etc.

A seguir estão as principais normas brasileiras relacionadas ao sistema construtivo em alvenaria estrutural.

\subsection{1 \\ NBR 15961: Alvenaria estrutural - Blocos de concreto}

\subsubsection{1}

\section{NBR 15961-1: Parte 1 - Projeto}

Esta norma fixa os requisitos mínimos exigíveis ao projeto de estruturas de alvenaria de blocos de concreto e tem os requisitos a seguir descritos.

- Qualidade da estrutura.

- Qualidade do projeto.

- Documentação do projeto.

O projeto deve prever uma estrutura apta a receber influências ambientais e ações que sobre ela produzam efeitos significativos tanto na sua construção quanto durante sua vida útil. Além disso, deve ser resistente a ações excepcionais como explosões e impactos sem apresentar danos desproporcionais às suas causas.

Deve ser projetado o sistema estrutural adequado à função desejada para a edificação com ações compatíveis e representativas, dimensionamento e verificação de todos os elementos estruturais presentes, especificação de materiais apropriados e de acordo com os dimensionamentos efetuados, além de procedimentos de controle para projeto.

Os desenhos técnicos devem apresentar plantas de todas as fiadas, exceto na altura das aberturas e a elevação de todas as paredes. O posicionamento dos 
blocos especiais devem estar indicados, bem como detalhes de amarração das paredes, localização dos pontos grauteados e armaduras e o posicionamento das juntas de controle e de dilatação.

As especificações devem conter as resistências à compressão dos componentes da estrutura, bem como a classe e a bitola dos aços a serem adotados.

\subsubsection{2}

\section{NBR 15961-2: Parte 2 - Execução e controle de obras}

Esta norma fixa os requisitos mínimos exigíveis para a execução e o controle de obras com estruturas de alvenaria de blocos de concreto.

Para a execução das obras, a norma tem como requisitos a verificação da locação, esquadros e nivelamento da base de assentamento da alvenaria conforme tolerâncias especificadas, o posicionamento dos reforços metálicos e das tubulações de acordo com o projeto, a limpeza do pavimento onde a alvenaria será executada para que outros materiais não prejudiquem a aderência da argamassa entre o bloco e o pavimento e a limpeza dos componentes e peças pré-fabricadas. Durante a elevação deve-se garantir que os blocos não sejam movidos depois de assentados para que não percam a aderência com a argamassa, que as paredes sejam executadas apenas com blocos inteiros e seus complementos (o uso de peças cortadas deve estar previsto em projeto e obtidas mediante condições controladas) e que as paredes estruturais não possuam amarração direta com paredes não estruturais.

Para o sistema de controle de obras, a norma estabelece planos de controle de qualidade onde devem estar explícitos os responsáveis pela execução do controle e circulação das informações, os responsáveis pelo tratamento e resolução das não conformidades e a forma de registro e arquivamento das informações. Estabelece ainda que o projeto executivo de alvenaria deverá estar devidamente compatibilizado com os demais projetos complementares e define os itens que devem ter procedimentos específicos no plano de controle: bloco de concreto, argamassa de assentamento, graute, prisma, recebimento e armazenamento de materiais, controle de produção da argamassa e do graute, controle sistemático da resistência do bloco ou certificações de qualidade, controle 
sistemático da argamassa e do graute, controle sistemático da resistência do prisma, controle dos demais materiais, controle de locação das paredes, controle de elevação de paredes, controle de execução dos grauteamentos e controle de aceitação da alvenaria.

\subsection{2}

\section{NBR 15270-2: Componentes cerâmicos - Parte 2 - Blocos cerâmicos para alvenaria estrutural - Terminologia e requisitos}

Esta norma fixa os requisitos dimensionais, físicos e mecânicos exigíveis no recebimento de blocos cerâmicos estruturais a serem utilizados em obras de alvenaria estrutural conforme descrições a seguir.

- Fabricação do bloco cerâmico (fabricado por conformação plástica de matéria-prima argilosos, contendo ou não aditivos, e queimado em elevadas temperaturas).

- Identificação (identificação da empresa, dimensões de fabricação em centímetros - LxHxC, indicação da condição estrutural e de rastreabilidade).

- Unidade de comercialização (milheiro para fins comerciais).

- Características visuais (não devem apresentar defeitos sistemáticos - quebras, superfícies irregulares ou deformações - e devem atender aos critérios de avaliação da aparência especificados em comum acordo entre fabricante e fornecedor).

- Características geométricas (deve apresentar forma de um prisma reto e as dimensões devem seguir as premissas da norma).

- Determinação das características geométricas (medidas das faces, espessura dos septos e paredes externas dos blocos, desvios em relação ao esquadro, planeza das faces, área bruta e área líquida); físicas (massa seca e índice de absorção) e mecânicas (resistência característica estabelecida por meio de ensaios de resistência à compressão individual). 


\subsection{3 \\ NBR 6136: Bloco vazado de concreto simples para alvenaria estrutural}

A norma fixa as condições para a aceitação de blocos vazados de concreto simples, confeccionados com cimento Portland, água e agregados minerais, com ou sem inclusão de outros materiais, destinados à execução de alvenaria estrutural e tem como requisitos gerais as que seguem.

- Classificação dos blocos vazados de concreto

- Quanto ao uso: classe AE - paredes externas acima ou abaixo do nível do solo que podem estar expostas à umidade ou intempéries e que não recebem revestimento de argamassa de cimento ou classe BE - limitada ao uso acima do nível do solo em paredes externas com revestimento de argamassa de cimento para proteção contra intempéries e em paredes não expostas às intempéries.

○ Quanto a resistência.

- Materiais

- Cimento (somente do tipo Portland).

- Água (deve ser limpa e isenta de produtos nocivos à hidratação do cimento).

- Agregados (agregados graúdos e miúdos de massa específica normal).

○ Aditivos e adições (permitidos desde que não acarretem efeitos prejudiciais, devidamente comprovados por ensaios e não devem conter substâncias potencialmente capazes de promover a deterioração do concreto dos blocos ou materiais próximos por contato direto ou por disseminação de íons).

- Dimensões (devem atender as dimensões padronizadas, a espessura mínima de quaisquer paredes dos blocos, menor dimensão do furo e mísulas de acomodação).

Além desta norma, foi publicada pelo Inmetro a portaria 220/13 de 29/04/2013 que estabelece as condições em que devem ser comercializados os blocos de concreto para alvenaria, bem como a metodologia para a determinação 
da dimensão efetiva dos mesmos visando a prevenção de práticas enganosas no mercado.

\subsection{4}

\section{NBR 10837: Cálculo de alvenaria estrutural de blocos vazados de concreto}

A norma fixa as condições exigíveis no projeto e execução de obras em alvenaria estrutural não armada, parcialmente armada ou armada, exclusivamente de blocos vazados de concreto, segundo a NBR 6136 e tem como condições gerais as que seguem.

- Projeto das estruturas

- Memórias de cálculo (composta de cálculos estáticos, da verificação da estabilidade global e local e da verificação da resistência dos diversos componentes estruturais da obra).

- Desenhos (planta de primeira fiada, elevação de todas as paredes resistentes contendo a localização das armaduras, grauteamentos, detalhes das amarrações das paredes, aberturas para passagens de canalizações e detalhe do projeto arquitetônico; especificação e quantidade dos materiais e componentes; resistências características dos blocos, dos prismas, do graute, da argamassa de assentamento e do aço; informações sobre outros componentes ou materiais utilizados e suas ligações com a alvenaria; juntas construtivas e juntas de dilatação; valores para sobrecargas fixas e sobrecargas de utilização conforme NBR 6120:2000; sequencia de execução quando esta influenciar a estabilidade ou resistência da obra e memorial descritivo).

- Solicitações

- Contraventamento de tal forma que não ocorram grandes deslocamentos relativos entre o topo e a base (paredes resistentes em dois sentidos e laje calculada como solidária 
com as paredes resistentes e funcionando como diagrama rígido transferindo a essas solicitações horizontais).

- Consideração de influência de cargas permanentes (próprio peso da estrutura e sobrecargas fixas) e acidentais e de todas as ações que possam produzir esforços importantes (vento, por exemplo).

○ Cálculo das cargas de estruturas laminares (paredes e lajes).

○ Cálculo das cargas de estruturas lineares (vergas e pilares).

\section{1 .5 \\ NBR 8949: Paredes de alvenaria estrutural - Ensaio a compressão simples}

A norma prescreve o método de preparo e de ensaio de paredes estruturais submetidas à compressão axial, construídas com blocos de concreto, blocos cerâmicos ou tijolos. Conjuntamente com as paredes serão preparados e ensaiados os blocos, os prismas, a argamassa de assentamento e o graute.

O relatório dos ensaios deve conter dentre outros, os itens seguintes.

- Tipo de alvenaria (blocos de concreto, cerâmicos ou tijolos), características geométricas das paredes, dos blocos ou tijolos, dos prismas e o posicionamento dos eventuais furos grauteados.

- Características gerais da construção das paredes, traço da argamassa de assentamento, do graute, e a localização por meio de desenhos, da posição das armaduras com a indicação dos seus diâmetros.

- Condições de cura das paredes, da argamassa e do graute;

- Data de construção e dos ensaios.

- Descrição da instrumentação utilizada e sua posição nas paredes.

- Tensões de rupturas individuais e médias dos blocos;

- Tensões de rupturas individuais e médias da argamassa de assentamento usada em cada parede.

- Tensões de rupturas individuais e médias do graute usado em cada parede. 
- Tensão de escoamento das armaduras e indicação do tipo de aço usado.

- Carga de ruptura das paredes.

- Carga do surgimento da primeira trinca (quando for possível a sua observação).

- Descrição do modo de ruptura das paredes.

- Gráficos cargas x encurtamentos.

- Gráficos cargas x flechas (quando a esbeltez da parede for superior a 25, sendo opcional nos outros casos).

- Descrição de eventuais anormalidades surgidas nos ensaios.

- Opcionalmente, fotografias para serem mostradas as condições gerais dos ensaios e para se registrar as suas eventuais peculiaridades.

\subsection{6 NBR 15873 - Coordenação modular para edificações}

Em vigor desde 2010, a norma especifica como padrão a medida de 100 mm para módulos básicos e define os termos e princípios da coordenação modular para edificações.

Com isso, os sistemas e componentes têm medidas padronizadas de forma industrial e são compatibilizados desde o projeto racionalizando a construção, aumentando a produtividade e reduzindo desperdícios.

Com relação aos quesitos de sustentabilidade, a Coordenação Modular reduz o consumo de matéria-prima e aumenta a capacidade de troca de componentes da edificação, facilitando as condições de manutenção (MARQUES, 2009). 


\section{5 \\ Certificações}

\section{1}

\section{Incentivos atuais com vistas à sustentabilidade}

Atualmente as grandes empresas construtoras têm se mostrado muito preocupadas com a questão ambiental. Como diferencial competitivo e melhoria interna de processos estão investindo cada vez mais em certificações de sustentabilidade.

As metas corporativas estão em constantes mudanças para melhor adaptação ao tema que passa a ser item imprescindível no mercado.

Os processos estão sendo reavaliados para que não apenas o cliente final, mas também as construtoras se beneficiem das melhorias como um todo.

Toda essa movimentação indica tendências de que futuramente as certificações se tornem item obrigatório.

Saem na frente as construtoras que vêm buscando pioneirismo na adaptação de seus processos.

Em seguida são apresentadas algumas das principais certificações.

\section{1 .1}

\section{Selo AQUA - Alta Qualidade Ambiental}

O processo AQUA é a adaptação para o Brasil da "Démarche HQE", da França e contém os requisitos para o Sistema de Gestão do Empreendimento (SGE) e os critérios de desempenho nas categorias da Qualidade Ambiental do Edifício (QAE). (Figura 5.1)

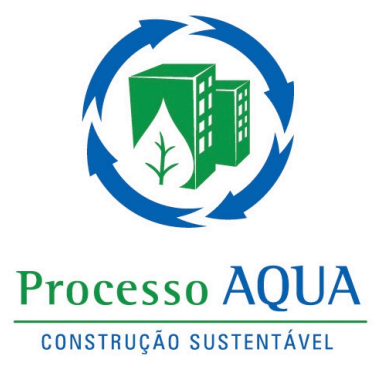

Figura 5.1 - Logomarca Processo AQUA - Construção Sustentável;

http://www.sustentech.com.br/wordpress/2011/10/selo-aqua---saiba-mais-sobre-aprimeira-certificacao-nascida-no-brasil/, visitado em: 30/03/2013. 
A iniciativa decorre de parceria entre a Fundação Carlos Alberto Vanzolini, o Departamento de Engenharia de Produção da Escola Politécnica da Universidade de São Paulo e o Centre Scientifique et Technique du Bâtiment (CSTB), instituto francês considerado referência mundial em pesquisas na construção civil.

O processo de avaliação e certificação ocorre em três fases distintas, classificadas como Programa, Concepção (Projeto), Realização (Obra) e Operação (Uso). Cada etapa recebe certificado específico.

Normalmente as construtoras são certificadas nas fases Programa, Concepção e Realização.

O AQUA considera em seu escopo de certificação as premissas da norma de desempenho NBR 15575:2013.

Além de estruturar todo o sistema de gestão do projeto dentro das diretrizes da certificação, devem ser atendidos requisitos mínimos de 14 categorias subdivididas em dois grandes grupos:

1. Gerenciar os impactos sobre o ambiente exterior

\section{Sítio e construção}

- Categoria 1: Relação do edifício com o seu entorno.

- Categoria 2: Escolha integrada de produtos, sistemas e processos construtivos.

- Categoria 3: Canteiro de obras com baixo impacto ambiental.

\section{Gestão}

- Categoria 4: Gestão da energia.

- Categoria 5: Gestão da água.

- Categoria 6: Gestão dos resíduos de uso e operação do edifício.

- Categoria 7: Manutenção- Permanência do desempenho ambiental.

2. Criar um espaço interior sadio e confortável

\section{Conforto}

- Categoria 8: Conforto higrotérmico.

- Categoria 9: Conforto acústico.

- Categoria 10: Conforto visual.

- Categoria 11: Conforto olfativo. 


\section{Saúde}

- Categoria 12: Qualidade sanitária dos ambientes.

- Categoria 13: Qualidade sanitária do ar.

- Categoria 14: Qualidade sanitária da água.

O desempenho associado às categorias se expressa segundo três níveis.

- BOM: nível correspondendo ao desempenho mínimo aceitável para um empreendimento de Alta Qualidade Ambiental. Isso pode corresponder à regulamentação, se esta é suficientemente exigente quanto aos desempenhos de um empreendimento, ou, na ausência desta, à prática corrente.

- SUPERIOR: nível correspondendo ao das boas práticas.

- EXCELENTE: nível calibrado em função dos desempenhos máximos constatados em empreendimentos de Alta Qualidade Ambiental, mas se assegurando que estes possam ser atingíveis.

Um produto em alvenaria estrutural pode contribuir para a certificação AQUA dentro das categorias a seguir descritas.

- Categoria 2: escolha integrada de produtos, sistemas e processos construtivos.

Dentro das exigências desta categoria, o sistema em alvenaria estrutural contribui para a diminuição da emissão de gases do efeito estufa, diminuição dos resíduos dispostos no ambiente, aumento do aproveitamento por reuso/reciclagem de materiais em função da otimização que vem desde o projeto e da utilização do bloco de concreto como material principal.

- Categoria 3: canteiro de obras com baixo impacto ambiental.

Dentro das exigências desta categoria, o sistema em alvenaria estrutural contribui com a minimização da produção de resíduos do canteiro de obras na fonte.

As situações em que um produto em alvenaria estrutural pode dificultar a certificação AQUA são descritas a seguir. 
- Varandas: por não permitir grandes balanços, as varandas em projetos de alvenaria estrutural não são tão generosas. Para o clima do Rio de Janeiro é interessante que janelas e portas fiquem recuadas para que não tenham incidência solar direta.

- Ventilações cruzadas: o ideal é que as unidades autônomas do edifício tenham vãos de ventilação voltados para no mínimo duas fachadas. Normalmente as lâminas possuem mais de quatro apartamentos por andar, o que dificulta esse tipo de solução. Para as unidades que tenham ventilações voltadas para uma mesma fachada, seria interessante que houvesse o deslocamento de um dos cômodos para se criar uma segunda fachada perpendicular a principal por onde esse cômodo pudesse ventilar. Porém, para a racionalização do sistema, não é conveniente que se tenham muitos recortes na fachada.

- Versatilidade de plantas: a certificação sugere a possibilidade de opções de plantas para os futuros clientes. A alvenaria estrutural, em função de exigências de dimensionamento, nem sempre permite muitas opções de planta. O mais comum nos projetos atuais é permitir o aumento da sala por meio da supressão de um dos quartos.

\section{1 .2}

\section{LEED - Leadership in Energy and Environmental Design}

O LEED é um sistema de certificação e orientação ambiental de edificações criado pelo U.S. Green Building Council. É o selo de maior reconhecimento internacional e o mais utilizado em todo o mundo, inclusive no Brasil (Figura 5.2).

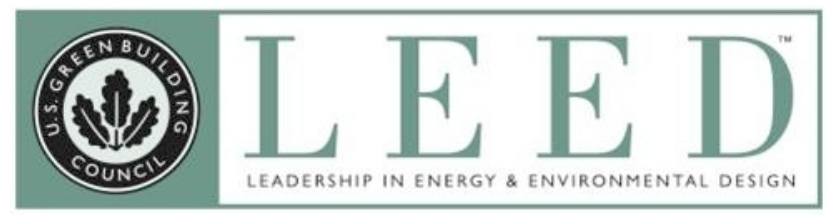

Figura 5.2 - Logomarca LEED - Leadership in Energy and Environmental Design; http://www.sustentech.com.br/wordpress/tag/leed-ga/, visitado em: 30/03/2013. 
O Green Building Council Brasil, criado em 2007, é uma organização não governamental que surgiu para auxiliar no desenvolvimento da indústria da construção sustentável no país, utilizando as forças de mercado para conduzir a adoção de práticas de Green Building em um processo integrado de concepção, construção e operação de edificações e espaços construídos.

As construtoras normalmente certificam no LEED NC (Novas construções e grandes projetos de renovação) e podem atingir diferentes níveis de certificação de acordo com o desempenho do produto (Silver, Gold e Platinum).

A certificação é baseada no atendimento aos pré-requisitos que somam um total de 110 pontos e são subdivididos da seguinte forma:

1. Espaço Sustentável - 26 pontos

Prevenção da poluição na atividade da construção

- Seleção do terreno.

- Densidade urbana e conexão com a comunidade

- Remediação de áreas contaminadas.

- Transporte alternativo (acesso ao transporte público, bicicletário e vestiário para os ocupantes, uso de veículos de baixa emissão e área de estacionamento).

- Desenvolvimento do espaço (proteção e restauração do habitat, maximizar espaços abertos).

- Projeto para águas pluviais (controle de qualidade)

- Redução da ilha de calor (áreas descobertas e áreas cobertas).

- Redução da poluição luminosa.

2. Uso Racional da Água - 10 pontos

Redução no uso da água.

- Uso eficiente de água no paisagismo (redução de 50\%, uso de água não potável ou sem irrigação).

- Tecnologias inovadoras para águas servidas.

- Redução do consumo de água (de 30 a 40 \%).

3. Energia e Atmosfera - 35 pontos

Comissionamento dos sistemas de energia.

Desempenho mínimo de energia

Gestão fundamental de gases refrigerantes. 
- Otimização da performance energética.

- Geração local de energia renovável.

- Melhoria no comissionamento.

- Melhoria na gestão de gases refrigerantes.

- Medições e verifícações.

- Energia verde.

4. Materiais e recursos -14 pontos

Depósito e coleta de materiais recicláveis.

- Reuso do edifício.

- Gestão de resíduos da construção

- Reuso de materiais.

- Conteúdo reciclado.

- Materiais regionais.

- Materiais de rápida renovação.

- Madeira certificada.

5. Qualidade ambiental interna -15 pontos

Desempenho mínimo na qualidade do ar interno.

Controle da fumaça do cigarro.

- Monitoramento do ar externo

- Aumento da ventilação.

- Plano de gestão da qualidade do ar.

- Materiais de baixa emissão.

- Controle interno de poluentes e produtos químicos.

- Controle de sistemas.

- Conforto térmico.

- Iluminação natural e paisagem.

6. Inovação e processo do projeto -6 pontos

- Inovação no projeto.

- Profissional acreditado LEED.

7. Créditos regionais -4 pontos

- Prioridades regionais.

A certificação é obtida de acordo com a pontuação abaixo:

Silver: $40-49$ pontos. 
Gold: 60-79 pontos.

Platinum: 80 pontos ou mais.

Um produto em alvenaria estrutural pode contribuir para a certificação LEED dentro dos seguintes pré-requisitos.

- Gestão de resíduos da construção: o sistema construtivo em alvenaria estrutural otimiza a geração de resíduos nos canteiros de obras por sua padronização.

- Reuso de materiais: por meio de uma unidade de materiais componentes do sistema pode-se reaproveitá-los através de transformações em mini usinas localizadas dentro ou fora dos canteiros de obra.

Situações em que um produto em alvenaria estrutural pode dificultar a certificação LEED.

- Inovação no projeto: em função da padronização do projeto, apresenta limitações que não permitem grandes inovações arquitetônicas mesmo em prol de melhores resultados com relação a ventilação e sombreamento do edifício.

- Aumento da ventilação: o dimensionamento das paredes estruturais pode impor limitações para a abertura de grandes vãos que permitam o aumento da ventilação nos compartimentos.

\section{1 .3}

\section{Selo Procel Edifica}

"O PROCEL promove o uso racional da energia elétrica em edificações desde sua fundação, sendo que, com a criação do PROCEL EDIFICA, as ações foram ampliadas e organizadas com o objetivo de incentivar a conservação e o uso eficiente dos recursos naturais (água, luz, ventilação etc.) nas edificações, reduzindo os desperdícios e os impactos sobre o meio ambiente." (ELETROBRAS: http://www.eletrobras.com, visitado em: 30/03/2013).(Figura 5.3).

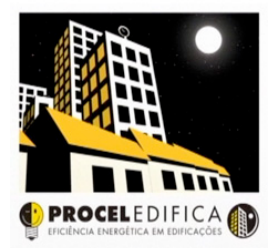

Figura 5.3-Logomarca Procel Edifica;

http://www.gruposage.net/public/index.php/atuacao/certificacao-2, visitado em:

30/03/2013. 
O programa funciona desde 2010 para edifícios residenciais. Um imóvel classe A, por exemplo, que é o mais eficiente em consumo, chega a proporcionar ao morador, de um edifício reformado para se adaptar às normas, 30\% de economia no consumo de energia elétrica e $50 \%$ se for um imóvel novo.

Para empreendimentos residenciais, a etiqueta pode ser concedida em dois momentos: na fase de projeto e após a construção do edifício.

A etiquetagem considera em suas premissas: acústica arquitetônica, clima urbano, desempenho térmico, equipamentos, iluminação, ventilação natural e sustentabilidade.

Com relação ao quesito sustentabilidade, o método pode contribuir pela racionalidade do processo construtivo e a menor geração de resíduos durante a execução da obra.

\section{1 .4}

\section{Selo Casa Azul}

O Selo Casa Azul CAIXA é um instrumento de classificação socioambiental de projetos de empreendimentos habitacionais, que busca reconhecer os empreendimentos que adotam soluções mais eficientes aplicadas à construção, ao uso, à ocupação e à manutenção das edificações, visando incentivar o uso racional de recursos naturais e a melhoria da qualidade da habitação e de seu entorno (Figura 5.4).

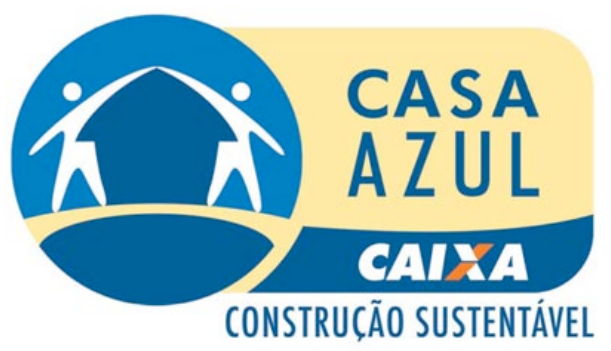

Figura 5.4 - Logomarca Selo Casa Azul - Construção sustentável; http://abrcasa.com.br/customizados/caixa/2010/06/construcao-habitacional-ganha-guia-desustentabilidade-do-selo-casa-azul/, visitado em: 30/03/2013. 
O Selo se aplica a todos os tipos de projetos de empreendimentos habitacionais apresentados à CAIXA para financiamento ou nos programas de repasse.

Podem se candidatar ao Selo as empresas construtoras, o Poder Público, as empresas públicas de habitação, as cooperativas, as associações e entidades representantes de movimentos sociais.

São 53 critérios de avaliação divididos em seis categorias:

1. Qualidade Urbana

1.1. Qualidade do entorno - infraestrutura (obrigatório).

1.2. Qualidade do entorno - impactos (obrigatório).

1.3. Melhorias no entorno.

1.4. Recuperação de áreas degradadas.

1.5. Reabilitação de imóveis.

2. Projeto e Conforto

2.1. Paisagismo (obrigatório).

2.2. Flexibilidade de projeto.

2.3. Relação com a vizinhança.

2.4. Solução alternativa de transporte.

2.5. Local para coleta seletiva (obrigatório).

2.6. Equipamentos de lazer, sociais e esportivos (obrigatório).

2.7. Desempenho térmico - vedações (obrigatório).

2.8. Desempenho térmico - orientação ao sol e ventos (obrigatório).

2.9. Iluminação natural de áreas comuns.

2.10. Ventilação e iluminação natural de banheiros.

2.11. Adequação as condições físicas do terreno.

3. Eficiência Energética

3.1. Lâmpadas de baixo consumo - áreas privativas (obrigatório).

3.2. Dispositivos economizadores - áreas comuns (obrigatório).

3.3. Sistema de aquecimento solar.

3.4. Sistema de aquecimento a gás. 
3.5. Medição individualizada - gás (obrigatório).

3.6. Elevadores eficientes.

3.7. Eletrodomésticos eficientes.

3.8. Fontes alternativas de energia.

4. Conservação de recursos materiais

4.1. Coordenação modular.

4.2. Qualidade de materiais e componentes (obrigatório).

4.3. Componentes industrializados ou pré-fabricados.

4.4. Formas e escoras reutilizáveis (obrigatório).

4.5. Gestão de resíduos de construção e demolição - RCD (obrigatório).

4.6. Concreto em dosagem otimizada.

4.7. Cimento de alto forno e pozolânico.

4.8. Pavimentação com RCD.

4.9. Facilidade de manutenção da fachada.

4.10. Madeira Plantada ou Certificada

5. Gestão da Água

5.1. Medição individualizada - Água (obrigatório).

5.2. Dispositivos economizadores - Sistema de Descarga (obrigatório).

5.3. Dispositivos economizadores - Arejadores.

5.4. Dispositivos economizadores - Registro Regulador de Vazão.

5.5. Aproveitamento de águas pluviais.

5.6. Retenção de águas pluviais.

5.7. Infiltração de águas pluviais.

5.8. Áreas permeáveis (obrigatório).

6. Práticas Sociais

6.1. Educação para a Gestão de RCD (obrigatório).

6.2. Educação ambiental dos empregados (obrigatório).

6.3. Desenvolvimento pessoal dos empregados.

6.4. Capacitação profisssional dos empregados.

6.5. Inclusão de trabalhadores locais.

6.6. Participação da comunidade na elaboração do projeto. 
6.7. Orientação aos moradores (obrigatório).

6.8. Educação ambiental dos moradores.

6.9. Capacitação para gestão do empreendimento.

6.10. Ações para mitigação de riscos sociais.

6.11. Ações para a geração de emprego e renda.

A obtenção do selo pode ocorrer em três níveis de gradação: Bronze (critérios obrigatórios); Prata (critérios obrigatórios e mais seis critérios de livre escolha); Ouro (critérios obrigatórios e mais doze critérios de livre escolha.

O principal objetivo é a conscientização ambiental e a promoção do uso racional dos recursos naturais como água e luz elétrica, além de reconhecer empreendimentos que reduzem custos de manutenção.

Um produto em alvenaria estrutural estaria apto a receber o Selo Casa Azul, levando em consideração os seguintes critérios.

- Coordenação modular: desde o projeto;

- Qualidade de materiais e componentes: uma vez que o sistema exige a criteriosa especificação e controle dos materiais a serem utilizados;

- Componentes industrializados ou pré-fabricados: normalmente utilizados no sistema;

- Formas e escoras reutilizáveis: pode-se utilizar também nesse sistema;

- Gestão de resíduos de construção: em função da padronização dos processos;

- Concreto em dosagem otimizada: determinado em projeto;

Situações em que um produto em alvenaria estrutural pode dificultar o recebimento do Selo Casa Azul:

- Flexibilidade de projeto: não há muita flexibilidade de plantas e fachadas em um projeto em alvenaria estrutural. 


\section{1 .5}

\section{Selo Santander}

O Santander tem uma política ambiental que estabelece regras de gerenciamento dos impactos ambientais diretos e indiretos, provenientes das atividades internas e do desenvolvimento de produtos e serviços financeiros do Banco (Figura 5.5).

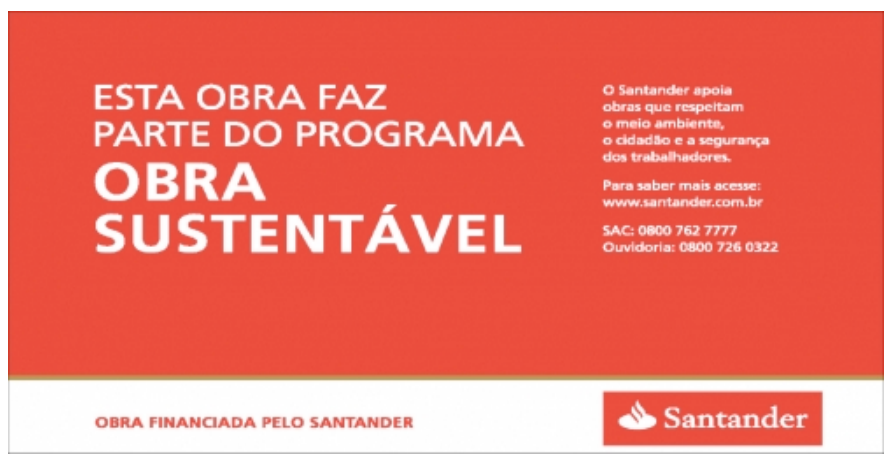

Figura 5.5 - Logomarca Selo Santander - Obra sustentável;

http://www.comunidadeobrasustentavel.com.br/blog.php?user=SistemAmbiental, visitado em: 30/03/2013.

Dentre esses serviços, destacam-se:

1) oportunidades nos negócios sustentáveis (Créditos de Carbono);

2) o Grupo Santander Brasil dá todo o suporte para que as empresas possam comercializar;

3) CER (Certified Emission Reductions, também conhecidas como créditos de carbono) no mercado mundial;

4) estímulo para construções mais sustentáveis (Santander Obra Sustentável).

O Santander criou o "Santander Obra Sustentável" para estimular a sustentabilidade na construção civil através de um novo modelo de relacionamento com as empresas que atuam no setor. Com esse programa o Santander fomenta práticas que aumentem a eficiência econômica, reduzem o impacto no meio ambiente e melhorem a qualidade de vida nas fases de planejamento e construção.

Para a viabilidade do financiamento do empreendimento é realizada uma avaliação por meio de ferramentas que abordam a extensão dos impactos 
socioambientais gerados pelo mesmo. Essa avaliação leva em consideração os itens a seguir descritos.
1) Planejamento do empreendimento.
2) Concepção do projeto.
3) Eficiência energética.
4) Conforto ambiental do edifício.
5) Conservação da água.
6) Seleção de materiais.
7) Saúde e bem estar do usuário.
8) Qualidade do empreendimento.
9) Construção.

10) Logística e segurança no canteiro de obras.

11) Gestão de resíduos sólidos e efluentes.

12) Comunicação com a comunidade do entorno do empreendimento.

13) Relacionamento com funcionários, fornecedores e parceiros.

Um empreendimento em alvenaria estrutural pode contribuir na avaliação considerando que o sistema reduz a quantidade de resíduos na obra além de facilitar a logística no canteiro de obra.

Também se pode levar em consideração a concepção do projeto considera a racionalização e seleção de materiais.

Um aspecto negativo é que a qualidade do empreendimento pode ficar prejudicada em função das limitações de soluções arquitetônicas diferenciadas e versatilidade de opções de plantas nas unidades.

\subsection{6}

\section{Selo Qualiverde}

A certificação tem origem em um projeto de lei complementar do poder executivo com o objetivo de estabelecer benefícios edilícios e fiscais para os empreendimentos que detenham a qualificação. 


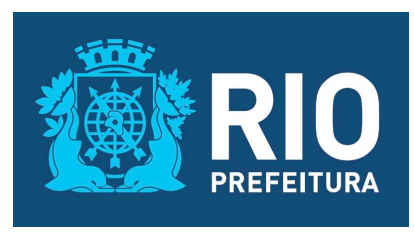

Figura 5.6 - Logomarca Prefeitura do Rio de Janeiro;

http://www2.rio.rj.gov.br/smu/compur/pdf/proposta_qualiverde.pdf, visitado em: 18/05/2013.

A qualificação é uma certificação concedida pela Prefeitura da Cidade do Rio de Janeiro, com o objetivo de incentivar a adoção de práticas sustentáveis. É aplicável a empreendimentos que contemplem ações para a redução das emissões de gases de efeito estufa e dos impactos ambientais.

É opcional e aplicável a projetos de novas edificações, onde se enquadram as construtoras, como também em edificações existentes, de uso residencial, comercial, misto ou institucional.

Nas edificações que obtiverem a qualificação não serão admitidas obras que descaracterizem as ações de sustentabilidade que justificaram a qualificação, nem atividades comerciais que causem incômodos ou prejuízo para a vizinhança e para o meio ambiente, devendo ser mantidas ou melhoradas as condições existentes.

Será qualificado o projeto que aplicar, no mínimo, 70\% dos pontos nas ações de sustentabilidade propostas no decreto.

Cada ação tem uma pontuação. Para efeitos dos benefícios, pode-se obter duas classificações: QUALIVERDE e QUALIVERDE 100.

Como benefícios estão previstos:

\section{Fiscais}

- Desconto do ISS na obra.

- Isenção/desconto de IPTU durante a obra.

- Isenção/desconto no ITBI.

- Desconto de IPTU no prédio.

\section{Edilícios}

- Isenção da área de varandas abertas e jardineiras no cômputo da ATE.

- Aumento de ocupação do pavimento de uso comum e dependências. 
- Cobertura do estacionamento localizado no pavimento térreo, desde que seja do tipo telhado verde e associada ao sistema de coleta, retenção ou reuso de águas pluviais.

As ações propostas estão divididas em:

- gestão da água;

- eficiência energética;

- desempenho térmico;

- projeto.

Dentro de cada uma dessas divisões estão listados os itens com as devidas pontuações.

Um empreendimento em alvenaria estrutural, considerando apenas o sistema estrutural e sem levar em consideração as demais soluções de projeto de outras disciplinas, já poderia contribuir para a pontuação dos seguintes itens.

- Vedações adequadas à zona bioclimática: se pensado em conjunto na concepção do projeto, o sistema pode facilitar essa solução.

- Reaproveitamento de resíduos do canteiro: levando em consideração a unidade de materiais que facilita esse processo.

Segundo LINS (2012), de acordo com suas análises específicas sobre o desempenho térmico em blocos de concreto, as construções de edifícios em alvenaria estrutural por si só não atingem os níveis mínimos de desempenho térmico determinados pela norma de desempenho NBR15575:2013 se não possuírem outros materiais atrelados ao sistema. São exemplos desses materiais: aplicação de reboco e vermiculita na face externa da fachada; utilização de drywall com isolamento em lã de rocha na face interna da fachada; aumento da espessura do vidro das esquadrias e alteração para a linha 25; utilização de telhado ventilado nas coberturas. 


\section{6 \\ Estudo de caso}

Neste capítulo serão estudados dois empreendimentos de médio padrão com sistema construtivo em alvenaria estrutural localizados no bairro do Recreio dos Bandeirantes, região em pleno desenvolvimento na cidade do Rio de Janeiro.

\section{1 \\ Empreendimento 1}

O empreendimento 1 foi lançado em 2011 e classificado como médio padrão, destinado a famílias de classe média.

As Figuras 6.1, 6.2, 6.3 e 6.4 ilustram a localização, a fachada, a implantação e a planta baixa de uma unidade autônoma desse empreendimento.

É constituído de sete blocos com oito unidades por pavimento. É composto de unidades de dois e três quartos com área entre $63 \mathrm{~m}^{2}$ e $85 \mathrm{~m}^{2}$. São cinco pavimentos tipo, do $2^{\circ}$ ao $6^{\circ}$ pavimentos com unidades de três quartos nas extremidades e unidades de dois quartos centrais. Também foram projetadas unidades no térreo, sendo nesse pavimento sete unidades por bloco.

Foi projetada uma área de lazer central externa com piscina, sauna, quadra, churrasqueiras e playground além de ambientes internos na projeção dos blocos como espaço fitness, espaço gourmet, salão de festas, espaço beleza, technolounge, salão de jogos, brinquedoteca e espaço bebê, todos comuns a todos os blocos. 


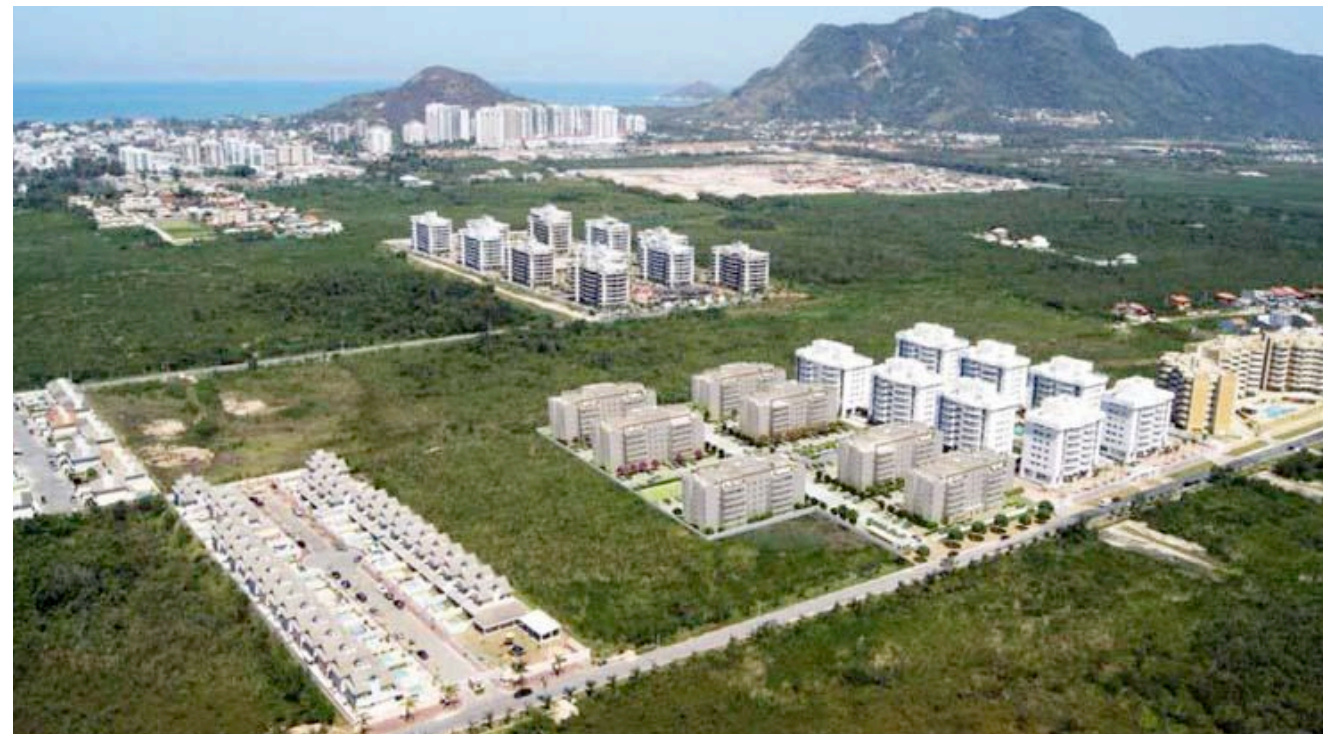

Figura 6.1 - Localização do empreendimento 1; http://lancamentosrj.com/imoveis-rio-dejaneiro/viverde-residencial-recreio-dos-bandeirantes.html, visitado em: 13/04/2014.

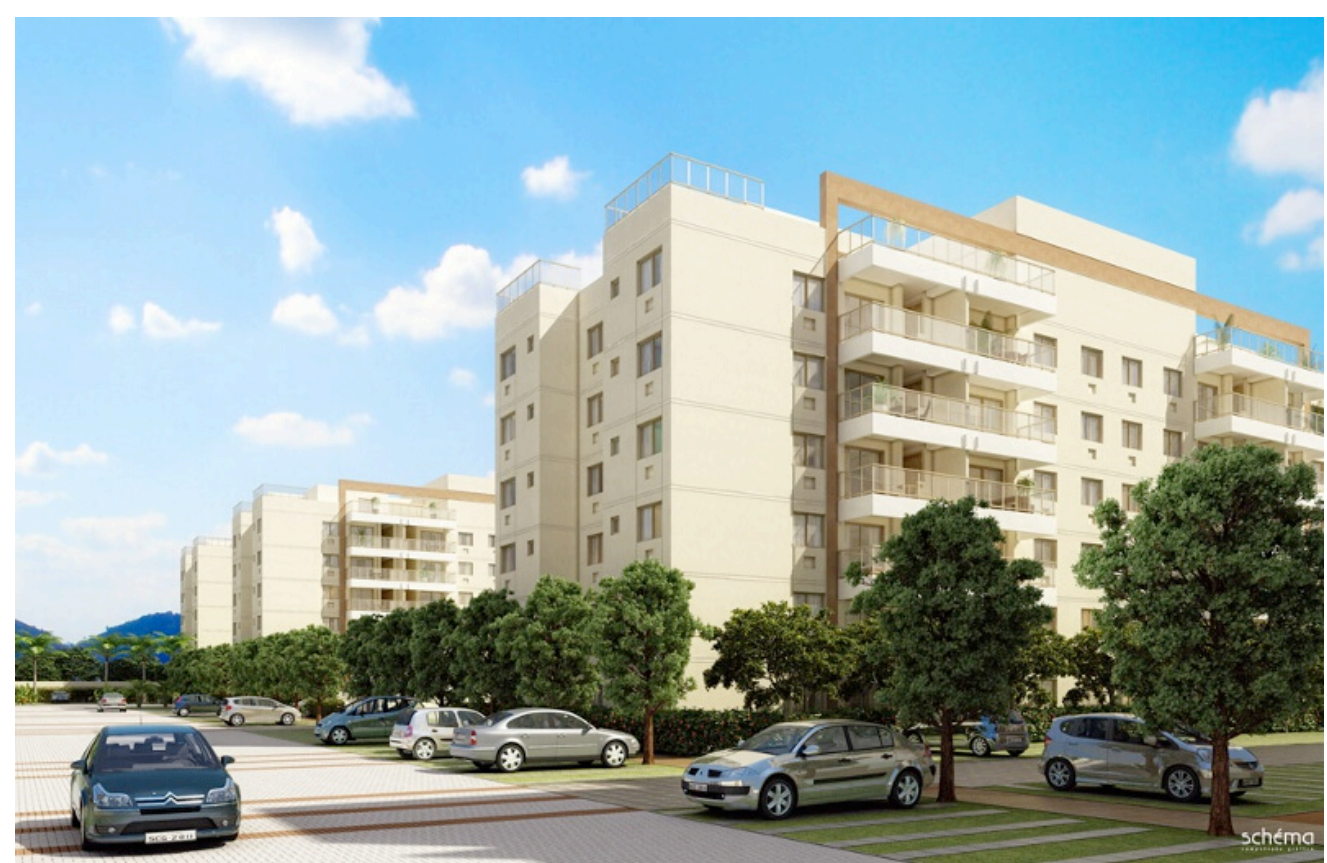

Figura 6.2 - Perspectiva ilustrativa da fachada do empreendimento 1; http://www.even.com.br/rj/rio-de-janeiro/recreio-dos-bandeirantes/residencial/viverderesidencial\#, visitado em: 18/05/2013. 


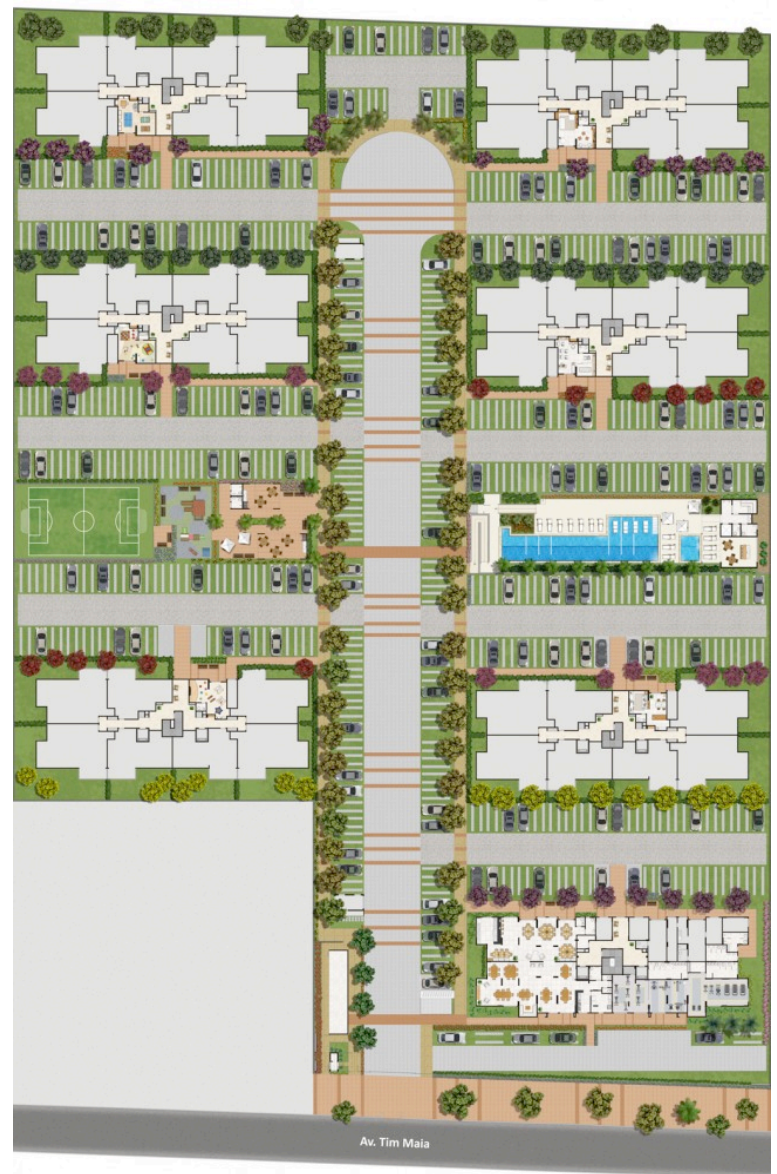

Figura 6.3-Masterplan do empreendimento 1;

http://www.schcg.com.br/portfolio/viverde-residencial/, visitado em: 18/05/2013.

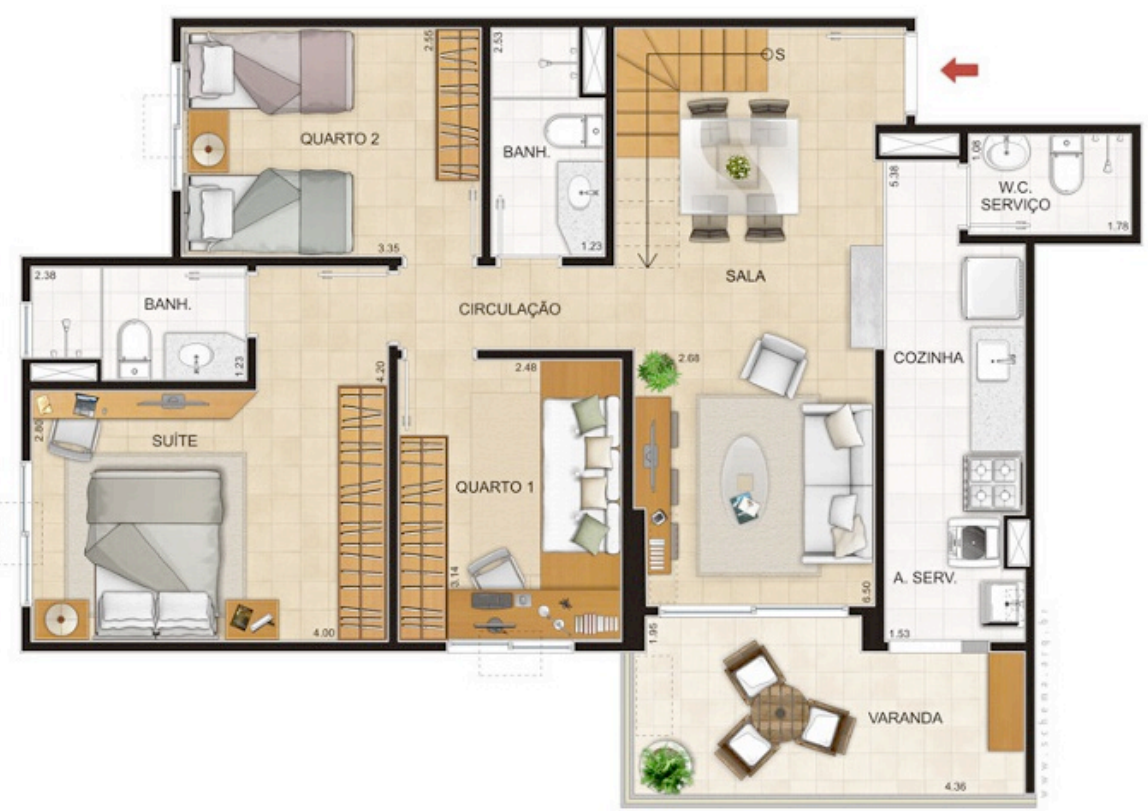

Figura 6.4 - Planta da unidade de 3 quartos do empreendimento 1

http://www.even.com.br/rj/rio-de-janeiro/recreio-dos-bandeirantes/residencial/viverderesidencial\#, visitado em: 18/05/2013. 


\section{2 \\ Empreendimento 2}

O empreendimento 2 está localizado em um novo bairro em implantação denominado no Recreio. As Figuras 6.5, 6.6, 6.7 e 6.8 ilustram a localização, a fachada, a implantação e a planta baixa de uma unidade autônoma desse empreendimento.

A primeira fase do empreendimento 2 foi lançada em 2013 que é classificado como médio padrão, também destinado a famílias de classe média.

Neste estudo avaliaremos a primeira das quatro fases do empreendimento, cujos blocos possuem 12 apartamentos por andar. É composto de unidades de dois e três quartos com área entre $58 \mathrm{~m}^{2}$ e $77 \mathrm{~m}^{2}$. São seis pavimentos tipo, do $2^{\circ}$ ao $7^{\circ}$ pavimentos com unidades de três quartos nas extremidades e unidades de dois quartos centrais. Também foram projetadas unidades no térreo, sendo nesse pavimento dez unidades por bloco.

Foi projetada uma área de lazer central externa com piscina, sauna, quadra, churrasqueira e playground além de ambientes internos na projeção dos blocos como academia, espaço gourmet, salão de festas adulto, salão de festas infantil e brinquedoteca. Esses espaços são comuns aos três blocos da fase 1. Cada fase tem o seu conjunto de áreas comuns.

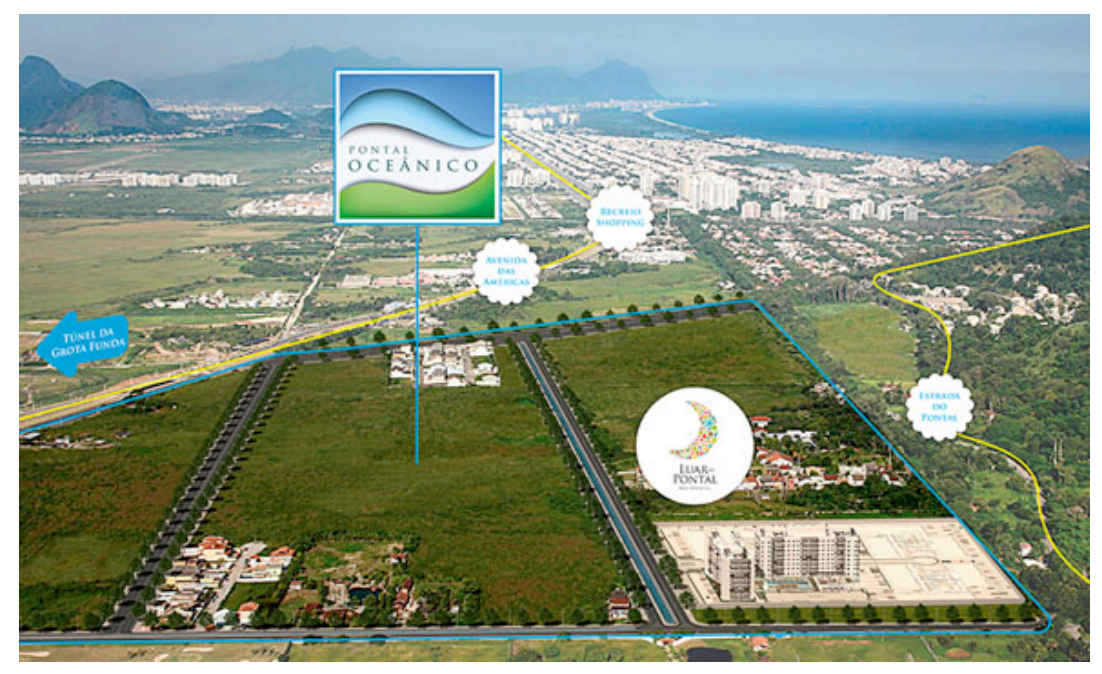

Figura 6.5 - Localização do empreendimento 2;

http://www.skyscrapercity.com/showthread.php?t=1626777\&page=4; visitado em: 13/04/2013. 


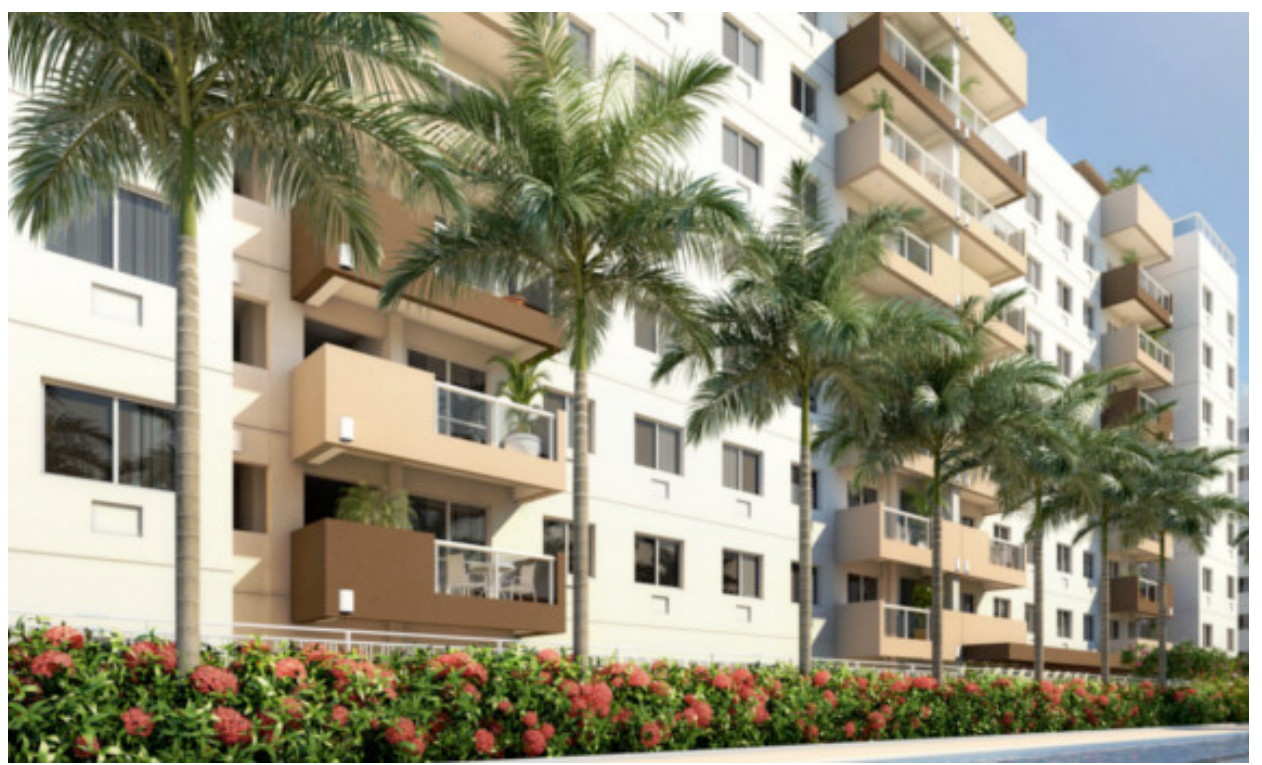

Figura 6.6 - Perspectiva ilustrativa da fachada do empreendimento 2;

http://www.even.com.br/rj/rio-de-janeiro/recreio-dos-bandeirantes/residencial/luar-dopontal-residencial?origem=google\&tipo=emp; visitado em: 13/04/2014.

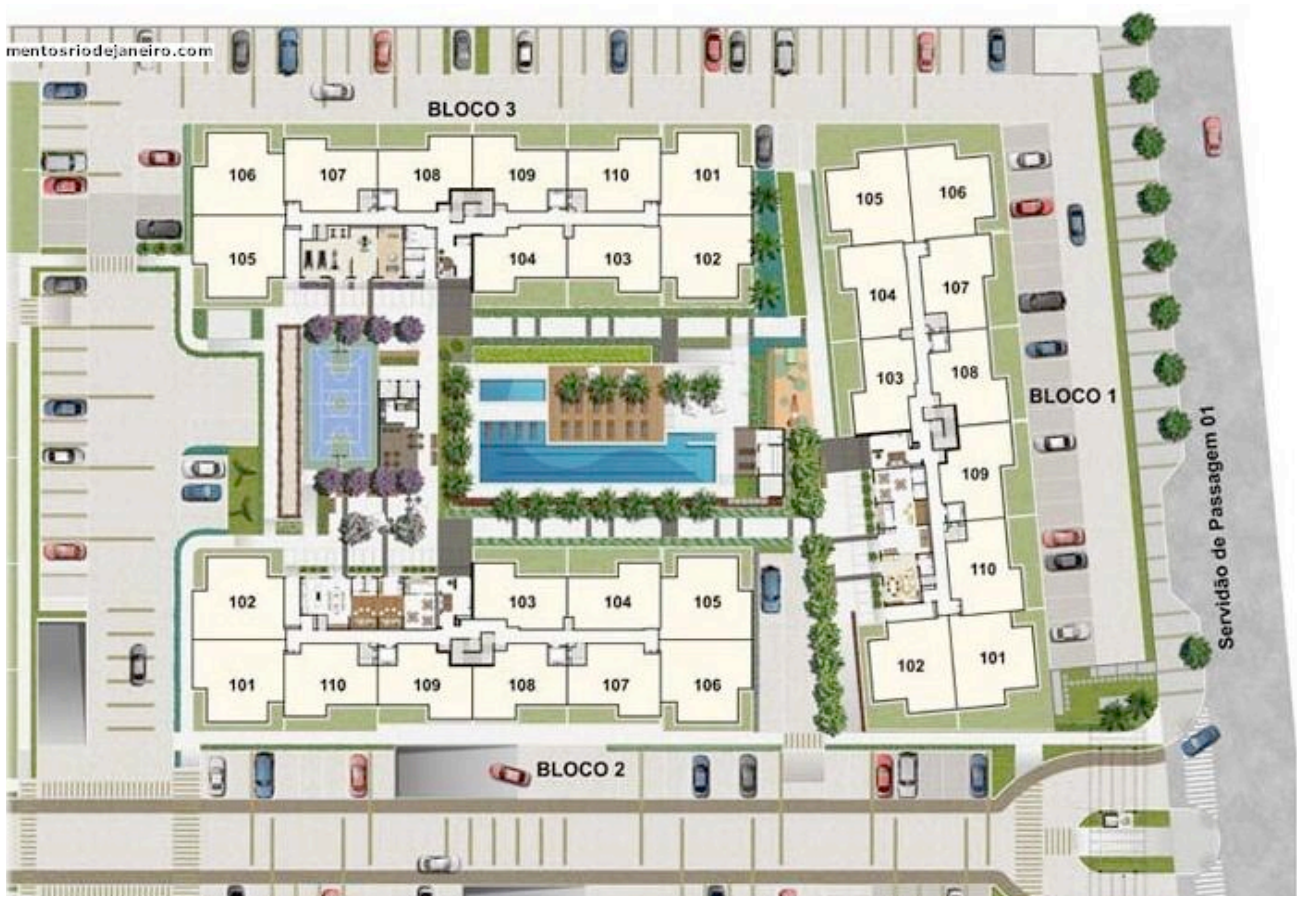

Figura 6.7 - Masterplan do empreendimento 2;

http://www.lancamentosriodejaneiro.com/imoveis/32/Rio-deJaneiro/Recreio/Apartamento/Luar-do-Pontal-Apto-de-2-e-3-quartos; visitado em: $13 / 04 / 2014$ 


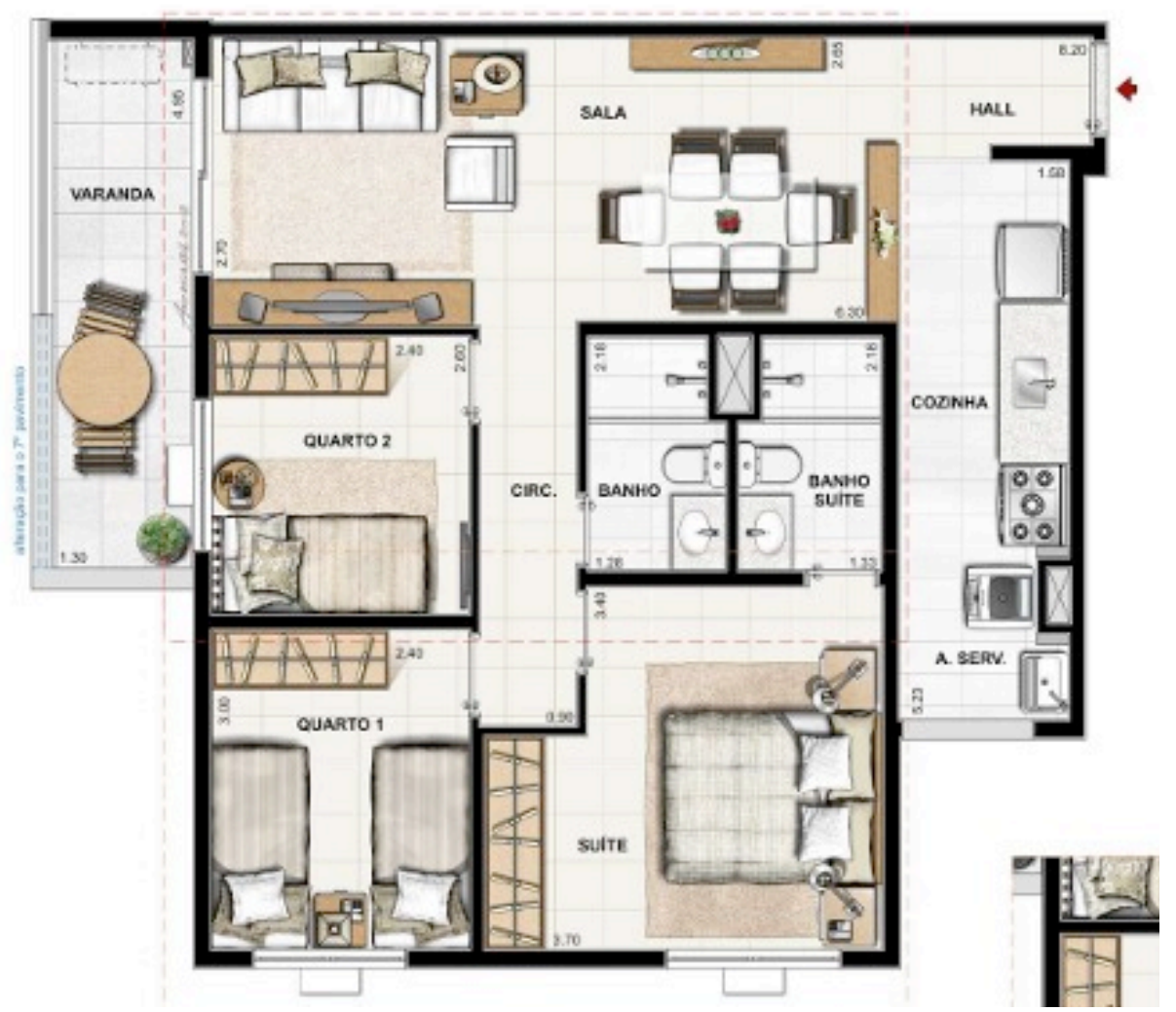

Figura 6.8 - Planta da unidade de 3 quartos do empreendimento 2. http://www.even.com.br/rj/rio-de-janeiro/recreio-dos-bandeirantes/residencial/luar-dopontal-residencial?origem=google\&tipo=emp; visitado em: 13/04/2014.

\section{3 Aspectos do sistema nos empreendimentos em questão}

Em ambos os empreendimentos os blocos são todos iguais e simétricos e as unidades são padronizadas, o que justifica o processo construtivo com a máxima repetição possível dos elementos.

Pode-se observar que as plantas de apartamentos são confortáveis, embora sua versatilidade não seja muito grande em função das limitações impostas pelo sistema estrutural adotado.

Em edificações executadas em alvenaria estrutural, as varandas normalmente não são muito generosas, já que para isso seria necessário uma solução mista de vigamentos para suportar o balanço das mesmas. No caso dos empreendimentos 1 e 2 , em função do padrão dos empreendimentos e da forte concorrência na região, a solução mista foi adotada o que gerou aumento no custo. 
As Figuras 6.9 e 6.10 mostram um exemplo de varanda quando não é adotada a solução mista, em que normalmente ficam embutidas e sem balanço e um exemplo de varanda de um dos concorrentes diretos em um empreendimento com estrutura convencional.

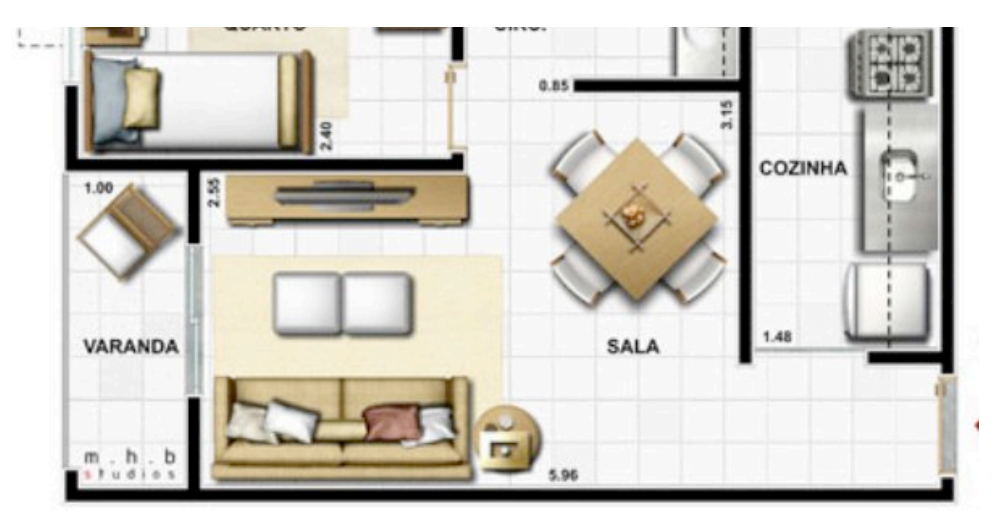

Figura 6.9 - Varanda embutida: empreendimento Minha Praia;

http://cidaderiodejaneiro.olx.com.br/2-quartos-jacarepagua-minha-praia-salvador-aliendeiid-499565898, visitado em: 30/06/2013.

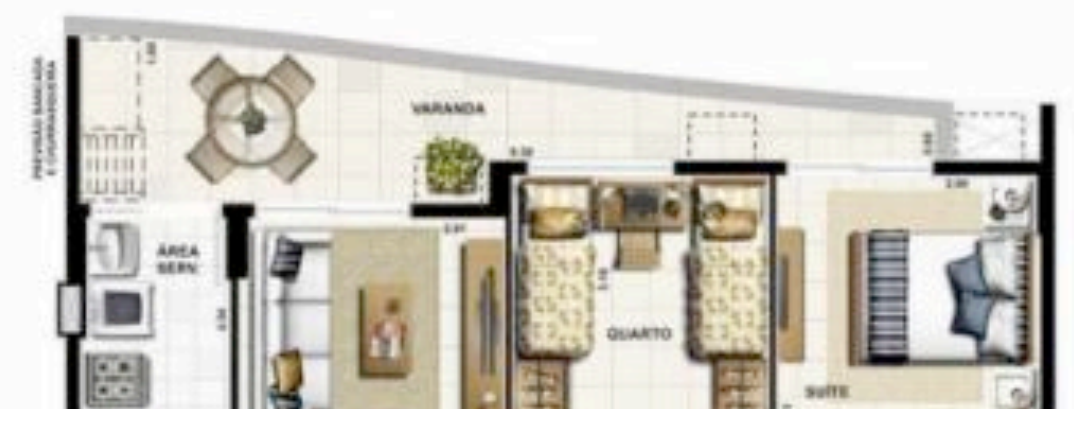

Figura 6.10 - Varanda do empreendimento Onda Carioca;

http://cidaderiodejaneiro.olx.com.br/lancamento-onda-carioca-apartamentos-iid362298787, visitado em: 30/06/2013.

Como a maioria das paredes são estruturais, não há muita versatilidade nas opções de alteração de plantas, já que muitas paredes não podem ser removidas. Na planta de três quartos pode-se ampliar a sala, porém, há a necessidade de se manter boa parte da parede estrutural fazendo com que a ampliação não seja completa como ilustra a Figura 6.11 a seguir. 


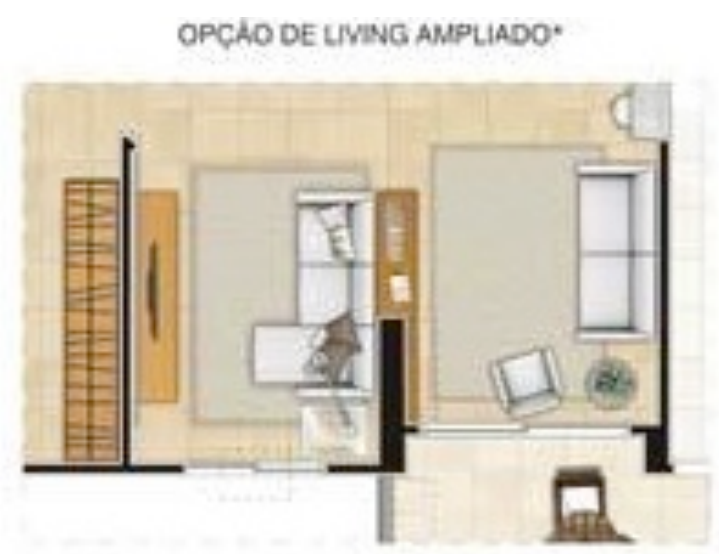

Figura 6.11 - Opção de ampliação da sala na planta da unidade de três quartos do empreendimento 1; http://www.even.com.br/rj/rio-de-janeiro/recreio-dosbandeirantes/residencial/viverde-residencial\#, visitado em: 18/05/2013.

A Figura 6.12 a seguir mostra um exemplo de ampliação de sala em um empreendimento concorrente com estrutura convencional.

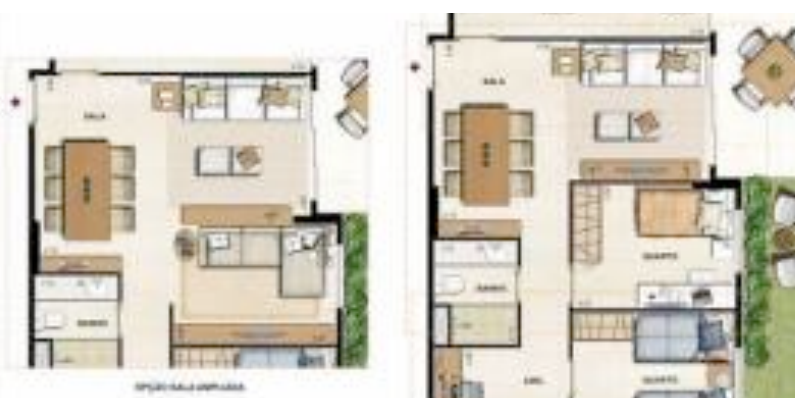

Figura 6.12 - Opção de ampliação da sala no empreendimento Park Premium;http://lancamentos.vivanuncios.com/empreendimentos+recreio/park-premiumrecreio-residences---/57700621visitado em: 30/06/2013.

Nos empreendimentos 1 e 2 foram projetadas unidades de cobertura, o que não é muito recorrente nesse tipo de sistema estrutural, pois a estrutura deve ter uma transição no último pavimento, fazendo com que as solicitações sejam recalculadas em função das novas paredes que surgem nesse andar em novas posições. Essa solução também pode encarecer um pouco mais o projeto. Porém, também foi necessário levar em consideração a concorrência ao aprovar essa decisão. As Figuras 6.13 e 6.14 mostram as plantas dos pavimentos inferior e superior de uma unidade de cobertura duplex do empreendimento 1. 


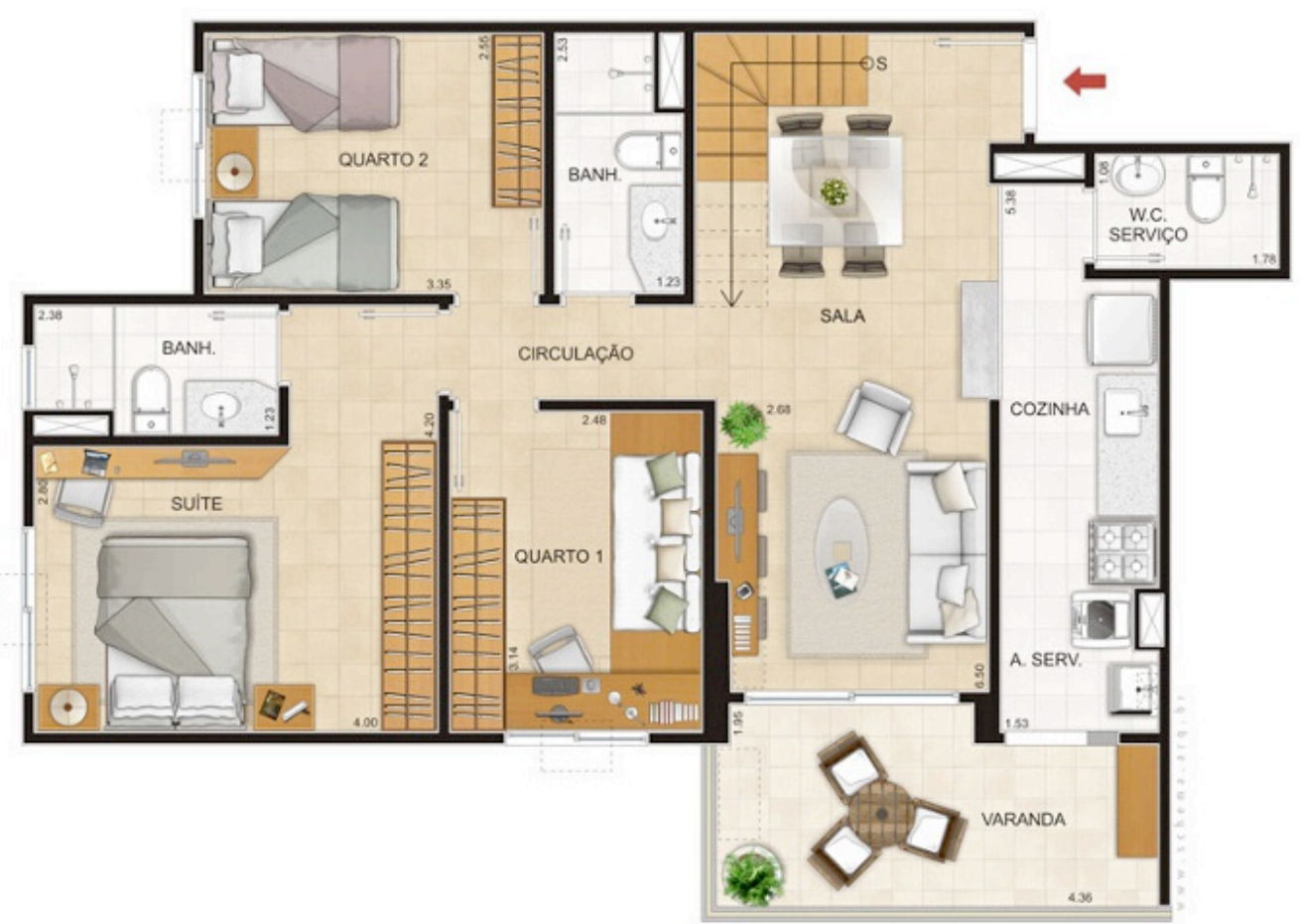

Figura 6.13 - Exemplo de planta de cobertura (pavimento inferior) do empreendimento 1; http://www.even.com.br/rj/rio-de-janeiro/recreio-dos bandeirantes/residencial/viverderesidencial\#, visitado em: 18/05/2013.

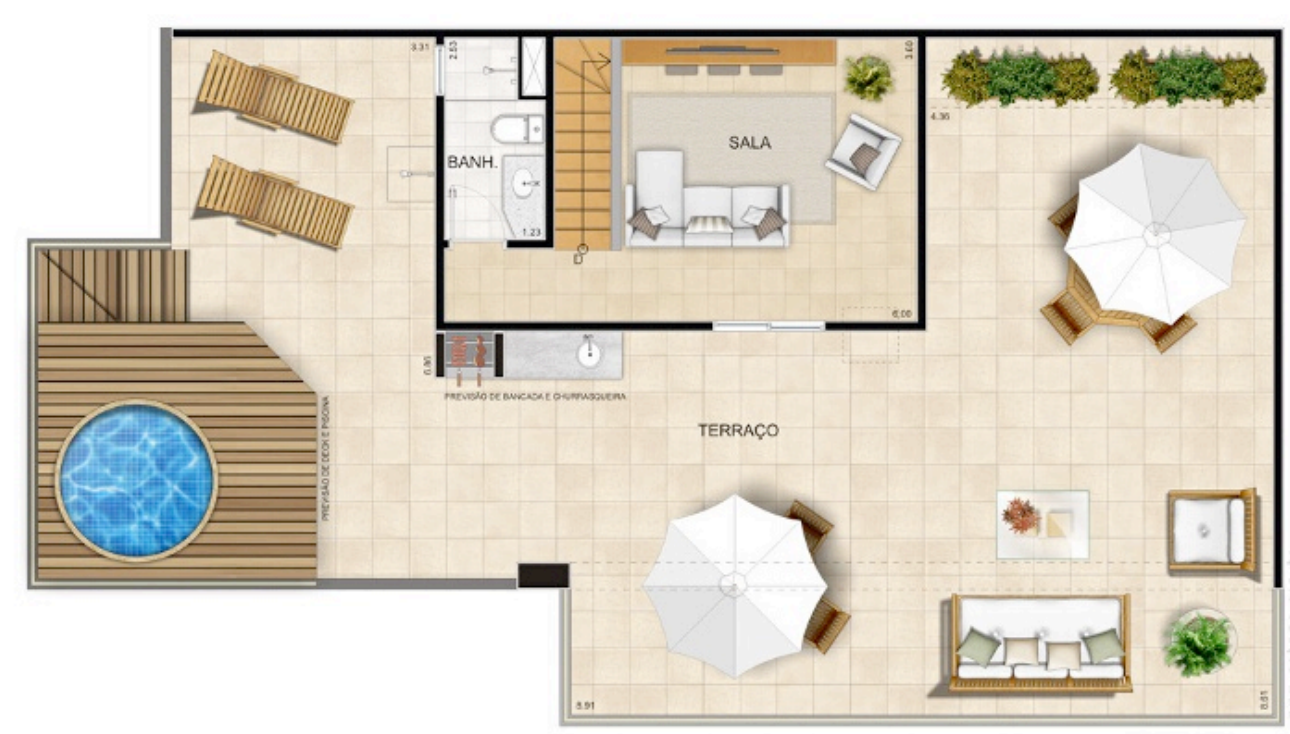

Figura 6.14 - Exemplo de planta de cobertura (pavimento superior) do empreendimento 1; http://www.even.com.br/rj/rio-de-janeiro/recreio-dos-bandeirantes/residencial/viverderesidencial\#, visitado em: 18/05/2013.

As Figuras 6.15 e 6.16 mostram exemplos de plantas de unidades de cobertura em empreendimentos concorrentes com estrutura convencional, e que 
impulsionaram a necessidade de se oferecer essa tipologia de apartamento também no empreendimento1.
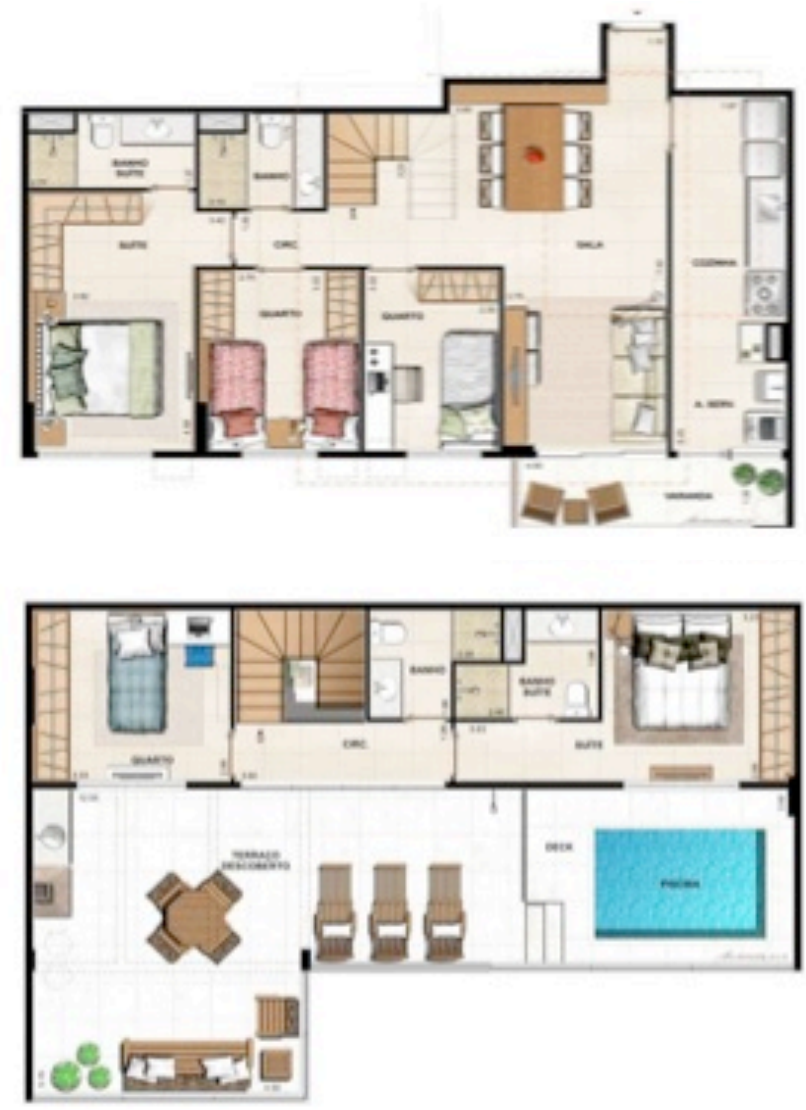

Figura 6.15 - Exemplo de planta de cobertura do empreendimento Park Premium; http://parkpremium.net/park-premium-recreio-plantas.html, visitado em: 30/06/2013.

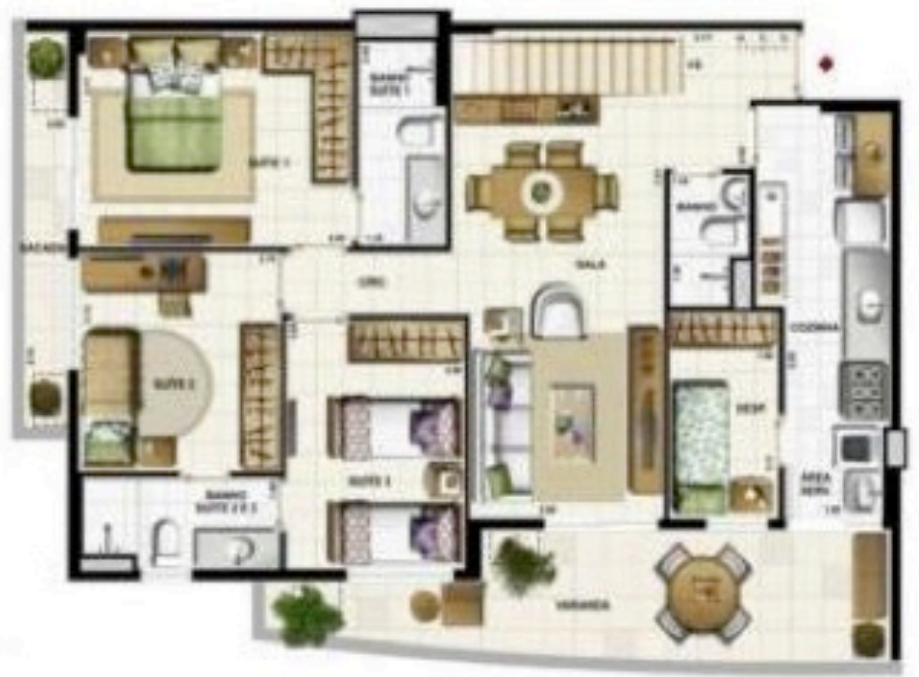

Figura 6.16 - Exemplo de planta de cobertura do empreendimento Onda Carioca; http://www.arrobacasa.com.br/onda-carioca-condominium-club-recreio/, visitado em: 30/06/2013. 


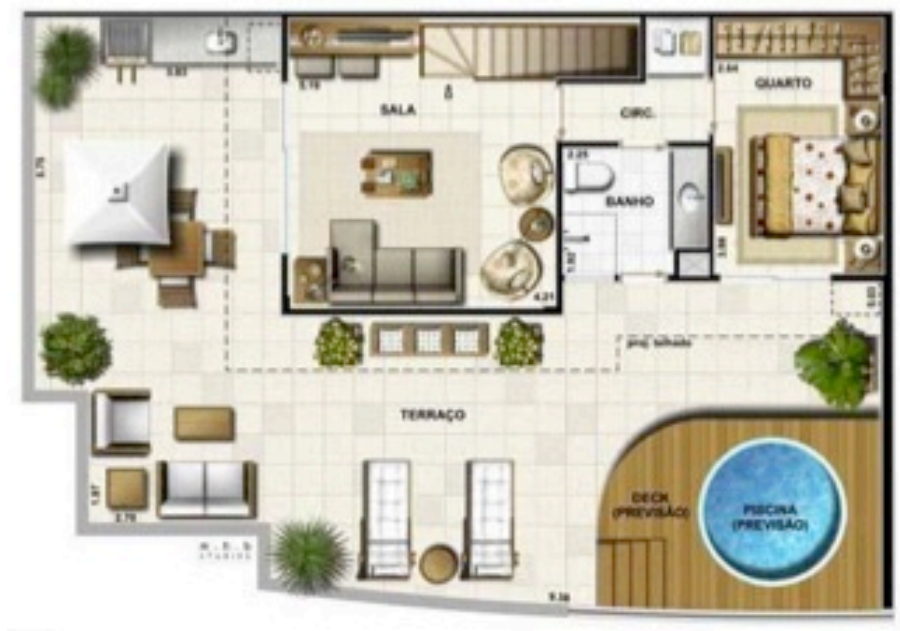

Figura 6.16 - Continuação.

Para garantir a viabilidade financeira da solução, no empreendimento 1 não foram projetados pavimentos de subsolo. Todas as vagas são descobertas distribuídas no pavimento térreo. Do ponto de vista do cliente final esse é um fator negativo. Já do ponto de vista de sustentabilidade, e conforme já previsto em algumas certificações, em algumas soluções onde não há estacionamentos cobertos é fundamental que se deixe pelo menos algumas áreas de embarque e desembarque cobertas no térreo sob a projeção dos blocos configurando uma espécie de pilotis coberto. Essa solução fica dificultada quando o edifício tem a alvenaria estrutural descendo até o pavimento térreo, já que as paredes do pavimento inferiores devem ser seguidas de acordo com o alinhamento dos pavimentos superiores.

No empreendimento 2, foi necessário o subsolo para se viabilizar a quantidade mínima de vagas exigidas por unidades conforme legislação local.

Nos empreendimentos 1 e 2 foram projetados ambientes de lazer nos térreos de cada bloco. Esses espaços foram previstos onde não há unidades autônomas. Na maioria dos blocos, a delimitação desses ambientes seguiu a disposição das paredes dos pavimentos superiores o que limitou um pouco as áreas. No empreendimento 1 , em um dos blocos, onde foi projetada a academia e o salão de festas, foram previstas vigas de transição com pilares de concreto para a eliminação de algumas paredes, para que o ambiente não ficasse prejudicado como ilustram as Figuras 6.17 e 6.18. 


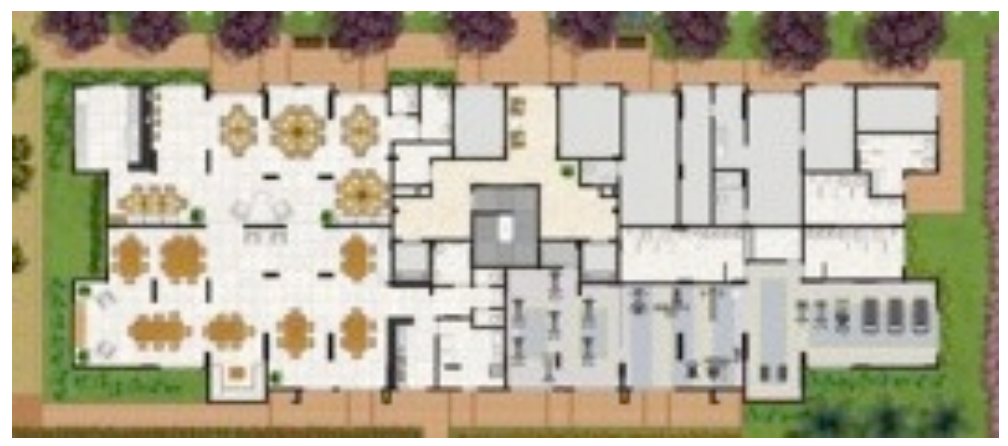

Figura 6.17 - Planta pavimento térreo de um dos blocos do empreendimento 1; http://www.schcg.com.br/portfolio/viverde-residencial/, visitado em: 19/05/2013.

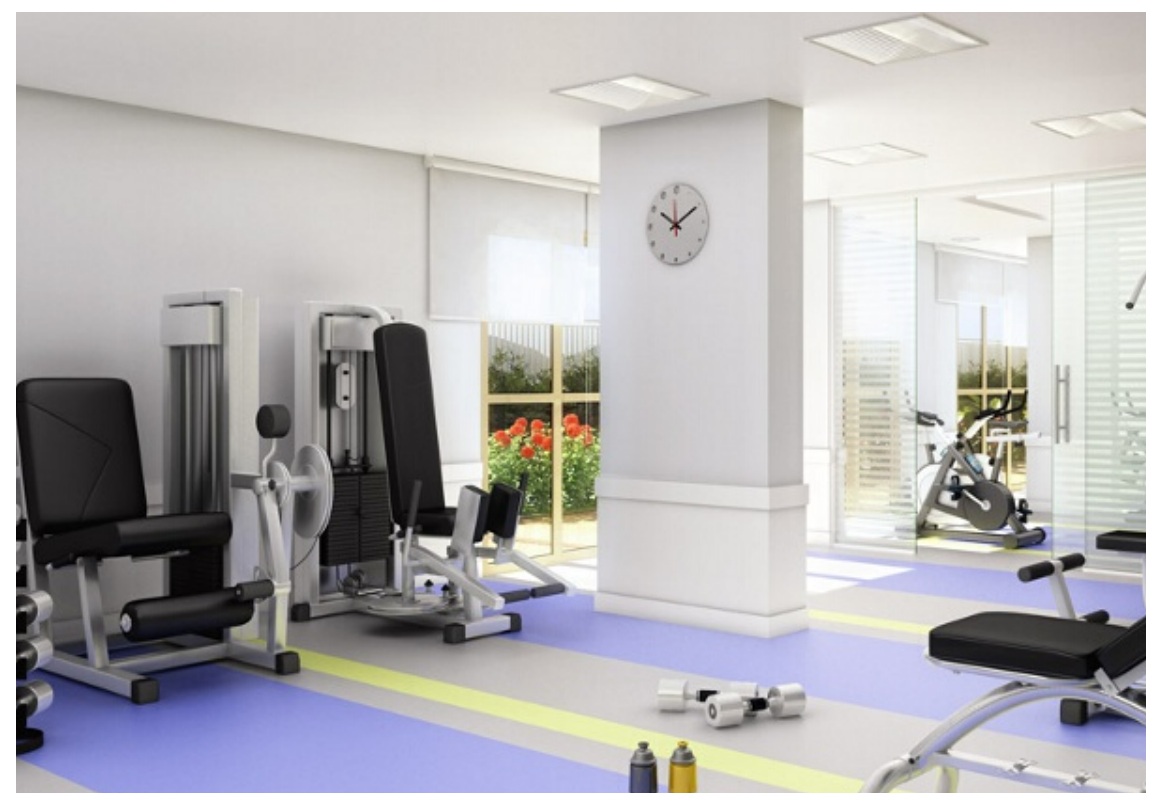

Figura 6.18 - Perspectiva ilustrativa da academia do empreendimento 1;

http://www.schcg.com.br/portfolio/viverde-residencial/, visitado em: 19/05/2013.

Porém, onde não há o recurso da viga de transição com pilares de concreto, os ambientes ficam bem limitados como mostram as Figuras 6.19 e 6.20 a seguir do empreendimento 2 . 

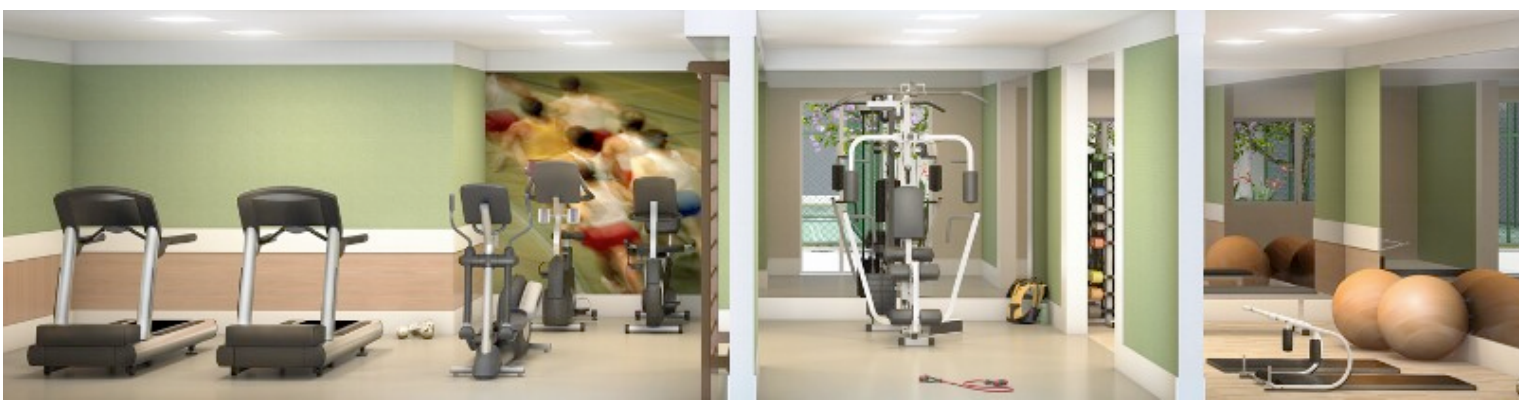

Figura 6.19 - Perspectiva da academia delimitada por paredes estruturais do

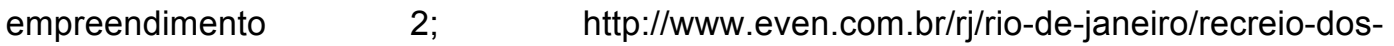
bandeirantes/residencial/luar-do-pontal-residencial?origem=google\&tipo=emp; visitado em: 13/04/2014.

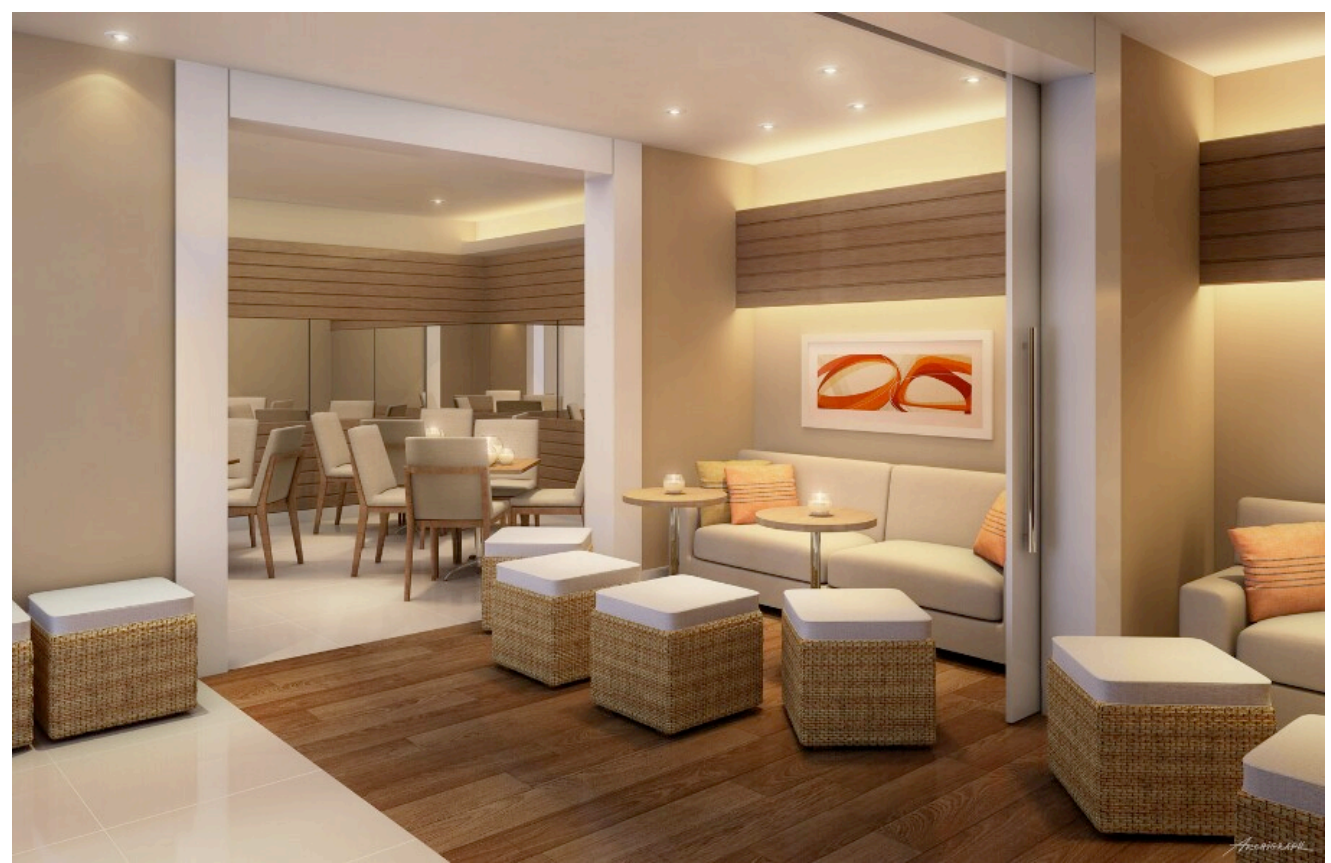

Figura 6.20 - Perspectiva ilustrativa do salão de festas delimitado por paredes estruturais do empreendimento 2; http://www.even.com.br/rj/rio-de-janeiro/recreio-dosbandeirantes/residencial/luar-do-pontal-residencial?origem=google\&tipo=emp; visitado em: 13/04/2014.

As Figuras 6.21 e 6.22 mostram exemplos de ambientes comuns em empreendimentos concorrentes com estrutura convencional com áreas bem superiores se comparadas às dos empreendimentos 1 e 2 . 


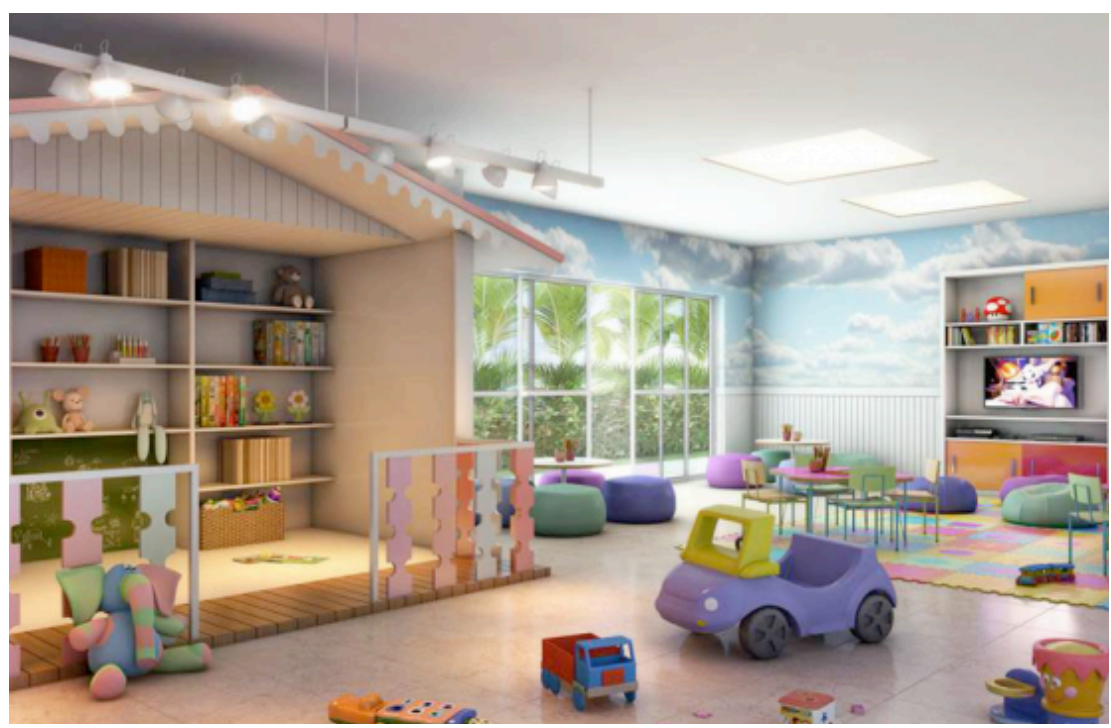

Figura 6.21 - Perspectiva ilustrativa da brinquedoteca do empreendimento Onda Carioca; http://cidaderiodejaneiro.olx.com.br/onda-carioca-condominium-club-iid391568102, visitado em: 30/06/2013.

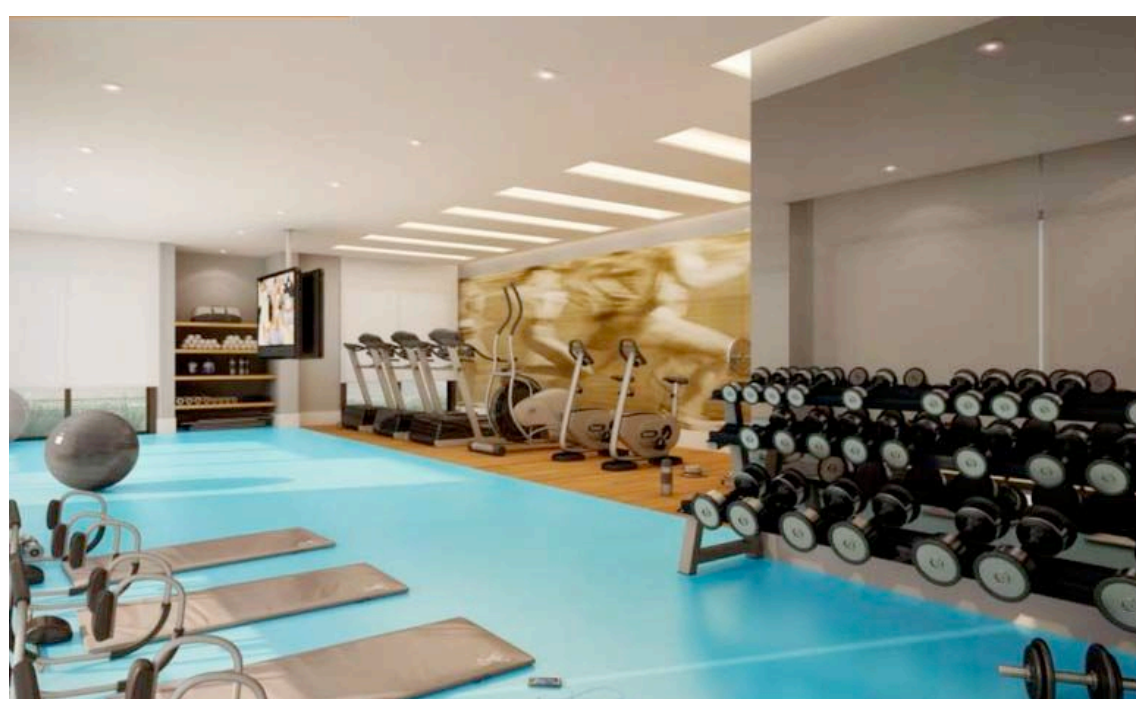

Figura 6.22 - Perspectiva ilustrativa da academia do empreendimento Park Premium; http://cidaderiodejaneiro.olx.com.br/onda-carioca-condominium-club-iid-391568102, visitado em: 30/06/2013.

Consideradas as necessidades comerciais de concepção do projeto e do produto, deve-se ainda levar em conta a parte técnica e construtiva do sistema estrutural para o resultado do empreendimento.

Não há dúvidas que a padronização e a modulação do projeto para a execução da obra geram benefícios com relação a sustentabilidade. 
A perda de material é muito menor com menos resíduos gerados e menor volume de desperdício.

O próprio processo de execução da obra é simplificado e isso faz com que o prazo possa ser encurtado.

Embora alguns aspectos comerciais fiquem comprometidos ao adotar esse sistema estrutural, os ganhos para a construtora são perceptíveis quando se consegue administrar todos os interesses de acordo com o empreendimento. Segundo SÁNCHEZ (2013), uma construção como a do empreendimento 1 e do empreendimento 2, com aproximadamente sete pavimentos, sem pilotis com alvenaria armada gera uma economia entre $15 \%$ e $20 \%$ em relação a um empreendimento em estrutura convencional.

Considerando-se o empreendimento 1 com uma área construída de aproximadamente $30.000,00 \mathrm{~m}^{2}$ e o valor do CUB em torno de $\mathrm{R} \$ 1.100,00 / \mathrm{m}^{2}$. Pode-se considerar que houve uma economia de R\$ 6.600.000,00 nesse empreendimento ao se comparar com a sua execução em estrutura convencional.

O empreendimento 2, tem área construída de aproximadamente 30.000,00 $\mathrm{m}^{2}$, mesmo com quase $10.000 \mathrm{~m}^{2}$ a menos de área privativa em relação ao empreendimento 1 , teria a mesma economia geral, porém, a eficiência do projeto não é tão boa.

Além da economia financeira o sistema emite menos $\mathrm{CO}_{2}$ comparado à estrutura de concreto armado. Com um cálculo aproximado considerando-se que os empreendimentos têm lajes de pavimento tipo com dimensões em torno de 20 m x 60 m, e utilizando-se dados do Manual FIB (Bulletin 67 - Guidelines for green concrete structures) tem-se a economia, conforme Tabela 6.1.

Tabela 6.1 - Análise da redução de emissão de $\mathrm{CO}_{2}$ nos empreendimentos em estudo.

\begin{tabular}{|c|c|c|c|c|c|c|c|c|c|c|}
\hline Empreend. & pav. tipo & área do & pav. $\left(\mathrm{m}^{2}\right)$ & total área \\
pav. $\left(\mathrm{m}^{2}\right)$ & $\begin{array}{c}\text { concreto } \\
\text { alvenaria } \\
\text { estrutural* }\end{array}$ & $\begin{array}{c}\text { volume } \\
\text { concreto } \\
\text { estrutura } \\
\text { convencional* } \\
\text { concreto } \\
\text { alvenaria } \\
\text { estrutural } \\
\left(\mathrm{m}^{3}\right)\end{array}$ & $\begin{array}{c}\text { volume total } \\
\text { concreto } \\
\text { estrutura } \\
\text { convencional } \\
\left(\mathrm{m}^{3}\right)\end{array}$ & $\begin{array}{c}\text { Diferença } \\
\text { de volume } \\
\text { de concreto } \\
\left(\mathrm{m}^{3}\right)\end{array}$ & $\begin{array}{c}\text { índice de } \\
\text { economia } \\
(\mathrm{kg} / \mathrm{kg})\end{array}$ & $\begin{array}{c}\text { Economia } \\
\text { de } \mathrm{CO}_{2}\left(\mathrm{~m}^{3}\right. \\
\mathrm{kg} / \mathrm{kg})\end{array}$ \\
\hline Empreendimento 1 & 5 & 1200 & 6000 & 0,12 & 0,22 & 720 & 1320 & 600 & 0,16 & 96 \\
\hline Empreendimento 2 & 6 & 1200 & 7200 & 0,12 & 0,22 & 864 & 1584 & 720 & 0,16 & 115,2 \\
\hline
\end{tabular}

*espessura da laje e demais componentes em concreto 
Nos casos de empreendimentos mais simples de padrão popular, o sistema ainda pode ser o mais aconselhado, tanto economicamente como do ponto de vista de sustentabilidade, uma vez que toda a padronização do partido arquitetônico do projeto é compatível com as premissas do projeto.

A seguir tem-se uma breve análise dos dois empreendimentos apresentados em relação à possibilidade em adquirir a certificação AQUA, que tem sido uma das mais buscadas para empreendimentos residenciais e que possui critérios de avaliação adaptados à realidade brasileira.

Algumas categorias só atingiriam o nível mínimo (bom) com a adoção de soluções construtivas diferenciadas no projeto ou no uso de materiais específicos.

Tabela 6.2 - Análise certificação AQUA nos empreendimentos de estudo.

\begin{tabular}{|c|c|c|c|c|c|}
\hline \multicolumn{2}{|r|}{ AQUA } & \multicolumn{2}{|r|}{ Empreendimento 1} & \multicolumn{2}{|r|}{ Empreendimento 2} \\
\hline & Categorias & Nível & & Nível & \\
\hline 1 & $\begin{array}{l}\text { Relação do edifício com } \\
\text { o seu entorno }\end{array}$ & Bom & $\begin{array}{l}\text { Situado em região em desenvolvimento } \\
\text { com poucos serviços no entorno imediato. } \\
\text { poderá sombrear e ser sombreado pelo } \\
\text { Viverde. Não estão disponíveis pontos de } \\
\text { ônibus, sendo o mais próximo a } \\
\text { aproximadamente } 2 \text { km de distância. Não } \\
\text { foram detectados impactos sonoros, } \\
\text { visuais ou olfativos, nem poluição do ar ou } \\
\text { eletromagnética. Estacionamento } \\
\text { descoberto com impossibilidade de } \\
\text { proteção de todos os caminhos entre } \\
\text { estacionamento e edifícios. }\end{array}$ & Superior & $\begin{array}{l}\text { O empreendimento está localizado em } \\
\text { área de recente crescimento e não } \\
\text { urbanizada, não existem problemas de } \\
\text { sombreamento. Também não estão } \\
\text { disponíveis pontos de ônibus ou outros } \\
\text { transportes públicos em decorrência } \\
\text { urbanização recente. } \\
\text { É possível proteger os caminhos entre } \\
\text { estacionamento e edifícios através do } \\
\text { subsolo. }\end{array}$ \\
\hline 2 & \begin{tabular}{|l|} 
Escolha integrada de \\
produtos, sistemas e \\
processos construtivos
\end{tabular} & $*$ & $\begin{array}{l}\text { As cozinhas não têm passagem livre de } 80 \\
\text { cm considerando os eletrodomésticos. } \\
\text { Além disso, não existe uma área específica } \\
\text { para os resíduos. Os produtos e materiais } \\
\text { da obra devem ser especificados } \\
\text { considerando níveis de desempenho } \\
\text { mínimo, devem estar em conformidade } \\
\text { com o PSQ e não praticar informalidades } \\
\text { na cadeia produtiva. O projeto possui } \\
\text { flexibilidade de opções de planta, porém } \\
\text { com restrições do sistema estrutural. }\end{array}$ & $*$ & $\begin{array}{l}\text { As cozinhas não têm passagem livre de } 80 \\
\text { cm considerando os eletrodomésticos. } \\
\text { Além disso, não existe uma área específica } \\
\text { para os resíduos. Os produtos e materiais } \\
\text { da obra devem ser especificados } \\
\text { considerando níveis de desempenho } \\
\text { mínimo, devem estar em conformidade } \\
\text { com o PSQ e não praticar informalidades } \\
\text { na cadeia produtiva. O projeto possui } \\
\text { flexibilidade de opções de planta, porém } \\
\text { com restrições do sistema estrutural. }\end{array}$ \\
\hline 3 & $\begin{array}{l}\text { Canteiro de obras com } \\
\text { baixo impacto } \\
\text { ambiental }\end{array}$ & Superior & $\begin{array}{l}\text { Planejamento das atividades e } \\
\text { treinamento da equipe de obra para } \\
\text { minimizizar incômodos aos vizinhos. } \\
\text { Informação aos vizinhos sobre as etapas } \\
\text { críticas de obra e sobre eventuais grandes } \\
\text { mobilizações. Comprometimento em } \\
\text { manter o canteiro e entorno limpos. } \\
\text { Groibição de queima no canteiro de obras. } \\
\text { minimizar resíduos gerados. Exigência de } \\
\text { redução do consumo de água e energia } \\
\text { por empresas contratadas. }\end{array}$ & Superior & $\begin{array}{l}\text { Planejamento das atividades e } \\
\text { treinamento da equipe de obra para } \\
\text { minimizar incômodos aos vizinhos. } \\
\text { Informação aos vizinhos sobre as etapas } \\
\text { críticas de obra e sobre eventuais grandes } \\
\text { mobilizações. Comprometimento em } \\
\text { manter o canteiro e entorno limpos. } \\
\text { Proibição de queima no canteiro de obras. } \\
\text { Gestão e organização do canteiro para } \\
\text { minimizar resíduos gerados. Exigência de } \\
\text { redução do consumo de água e energia } \\
\text { por empresas contratadas. }\end{array}$ \\
\hline
\end{tabular}


Tabela 6.2 - Continuação.

\begin{tabular}{|c|c|c|c|c|c|}
\hline 4 & Gestão da energia & * & $\begin{array}{l}\text { As janelas não atendem à taxa mínima de } \\
\text { ventilação nem de iluminação. Os quartos } \\
\text { e salas, que devem atender } 10 \% \text { da área } \\
\text { para ventilação e alcançam em média, } 8 \% . \\
\text { Uma vez ajustadas para alcançar o nível } \\
\text { estipulado para a ventilação, os vãos } \\
\text { alcançarão, em sua maioria, os níveis } \\
\text { necessários para iluminação. Não foi } \\
\text { avaliada a possibilidade de utilização de } \\
\text { energia renovável, nem há sistemas } \\
\text { específicos e separados para } \\
\text { monitoramento do consumo de energia. }\end{array}$ & * & $\begin{array}{l}\text { As janelas não atendem à taxa mínima de } \\
\text { ventilação nem de iluminação. Os quartos } \\
\text { e salas, que devem atender } 10 \% \text { da área } \\
\text { para ventilação e alcançam em média, } 8 \% \text {. } \\
\text { Uma vez ajustadas para alcançar o nível } \\
\text { estipulado para a ventilação, os vãos } \\
\text { alcançarão, em sua maioria, os níveis } \\
\text { necessários para iluminação. Não foi } \\
\text { avaliada a possibilidade de utilização de } \\
\text { energia renovável, nem há sistemas } \\
\text { específicos e separados para } \\
\text { monitoramento do consumo de energia. }\end{array}$ \\
\hline 5 & Gestão da água & Bom & $\begin{array}{l}\text { O empreendimento atinge a área de } \\
\text { permeabilidade mínima exigida para o } \\
\text { lote e possui sistema de aproveitamento } \\
\text { de águas pluviais bem como medição } \\
\text { individualizada de água. }\end{array}$ & Bom & $\begin{array}{l}\text { O empreendimento atinge a área de } \\
\text { permeabilidade mínima exigida para o } \\
\text { lote e possui sistema de aproveitamento } \\
\text { de águas pluviais bem como medição } \\
\text { individualizada de água. }\end{array}$ \\
\hline 6 & $\begin{array}{l}\text { Gestão dos resíduos de } \\
\text { uso e operação do } \\
\text { edifício }\end{array}$ & $*$ & $\begin{array}{l}\text { O layout das cozinhas não comporta a } \\
\text { área de resíduos mínima de } 0,3 \mathrm{~m}^{2} \text {. Não } \\
\text { há no empreendimento um espaço para } \\
\text { colocação de caçambas ou baias de } \\
\text { triagem para resíduos de futuras obras, } \\
\text { nem um depósito para resíduos especiais. } \\
\text { Existe um depósito único próximo ao } \\
\text { acesso, porém distante de alguns blocos. } \\
\text { O ideal seria ter um depósito } \\
\text { intermediário em cada bloco. } \\
\text { Identificação dos resíduos gerados nas } \\
\text { atividades desenvolvidas nas unidades } \\
\text { habitacionais e nas áreas comuns e } \\
\text { apresentação de sua classificação } \\
\text { conforme natureza e potencial de } \\
\text { valorização. Identificação da frequência da } \\
\text { coleta para adequação do sistema. } \\
\text { Recomendações nos Manuais do } \\
\text { Proprietário e do Síndico. }\end{array}$ & $*$ & $\begin{array}{l}\text { O layout das cozinhas não comporta a } \\
\text { área de resíduos mínima de } 0,3 \mathrm{~m}^{2} \text {. Não } \\
\text { cá no empreendimento um espaço para } \\
\text { triagem para resíduos de futuras obras, } \\
\text { nem um depósito para resíduos especiais. } \\
\text { Existe um depósito de lixo provisório } \\
\text { próximo ao acesso e depósitos finais para } \\
\text { cada bloco próximos aos elevadores. } \\
\text { Necessidade de identificação dos resíduos } \\
\text { gerados nas atividades desenvolvidas nas } \\
\text { unidades habitacionais e nas áreas } \\
\text { comuns e apresentação de sua } \\
\text { classificação conforme natureza e } \\
\text { potencial de valorização. Identificação da } \\
\text { frequência da coleta para adequação do } \\
\text { sistema. Recomendaçães nos Manuais do } \\
\text { Proprietário e do Síndico. }\end{array}$ \\
\hline 7 & $\begin{array}{l}\text { Manutenção - } \\
\text { Permanência do } \\
\text { desempenho ambiental }\end{array}$ & Superior & $\begin{array}{l}\text { O local de armazenamento de resíduos } \\
\text { deve possuir abertura para o exterior, ser } \\
\text { bem iluminados e com ponto de água e } \\
\text { ralo. Os medidores individuais devem } \\
\text { estar acessíveis. Devem ser previstas } \\
\text { recomendações sobre o uso, manutenção } \\
\text { e operação no manual do proprietário e } \\
\text { do síndico. }\end{array}$ & Superior & $\begin{array}{l}\text { O local de armazenamento de resíduos } \\
\text { deve possuir abertura para o exterior, ser } \\
\text { bem iluminados e com ponto de água e } \\
\text { ralo. Os medidores individuais devem } \\
\text { estar acessíveis. Devem ser previstas } \\
\text { recomendações sobre o uso, manutenção } \\
\text { e operação no manual do proprietário e } \\
\text { do síndico. }\end{array}$ \\
\hline 8 & Conforto higrotérmico & * & $\begin{array}{l}\text { Necessidade de adequação das vedações } \\
\text { externas para atendimento aos níveis de } \\
\text { fator de ganho de calor solar de } \\
\text { elementos opacos e de transmitância } \\
\text { térmica adequados à zona bioclimática da } \\
\text { cidade do Rio de Janeiro. Quando os vão } \\
\text { não estão sombreados por varandas ou } \\
\text { sacadas, devem ser projetadas persianas } \\
\text { integradas ou brises. }\end{array}$ & $*$ & $\begin{array}{l}\text { Necessidade de adequação das vedações } \\
\text { externas para atendimento aos níveis de } \\
\text { fator de ganho de calor solar de } \\
\text { elementos opacos e de transmitância } \\
\text { térmica adequados à zona bioclimática da } \\
\text { cidade do Rio de Janeiro. Quando os vão } \\
\text { não estão sombreados por varandas ou } \\
\text { sacadas, devem ser projetadas persianas } \\
\text { integradas ou brises. }\end{array}$ \\
\hline 9 & Conforto acústico & $*$ & $\begin{array}{l}\text { Necessidade de adequação das vedações } \\
\text { para atendimento aos níveis de pressão } \\
\text { sonora padrão ponderado (L'nT,w) através } \\
\text { de engrossamento ou preenchimento de } \\
\text { paredes, bem como pelo uso de } \\
\text { esquadrias com tratamento acústico. } \\
\text { Avaliação da espessura da laje para } \\
\text { atendimento ao nível mínimo exigido } \\
\text { considerando o ruído aéreo entre } \\
\text { unidades. }\end{array}$ & $*$ & $\begin{array}{l}\text { Necessidade de adequação das vedações } \\
\text { para atendimento aos níveis de pressão } \\
\text { sonora padrão ponderado (L'nT,w) através } \\
\text { de engrossamento ou preenchimento de } \\
\text { paredes, bem como pelo uso de } \\
\text { esquadrias com tratamento acústico. } \\
\text { Avaliação da espessura da laje para } \\
\text { atendimento ao nível mínimo exigido } \\
\text { considerando o ruído aéreo entre } \\
\text { unidades. }\end{array}$ \\
\hline
\end{tabular}


Tabela 6.2 - Continuação.

\begin{tabular}{|c|c|c|c|c|c|}
\hline 10 & Conforto visual & Bom & $\begin{array}{l}\text { Projeto contempla iluminação natural nas } \\
\text { unidades habitacionais. lluminação por } \\
\text { sensores de movimento em alguns } \\
\text { ambientes das áreas comuns. Deverá ser } \\
\text { calculado o FLD (fator de luz diurna) para } \\
\text { confirmação dos índices principalmente } \\
\text { nas unidades do térreo entre blocos onde } \\
\text { as salas possuem esse valor mais crítico } \\
\text { em função do sombreamento das } \\
\text { varandas nas salas. }\end{array}$ & Bom & $\begin{array}{l}\text { Projeto contempla iluminação natural nas } \\
\text { unidades habitacionais. lluminação por } \\
\text { sensores de movimento em alguns } \\
\text { ambientes das áreas comuns. Deverá ser } \\
\text { calculado o FLD (fator de luz diurna) para } \\
\text { confirmação dos índices principalmente } \\
\text { nas unidades do térreo entre blocos onde } \\
\text { as salas possuem esse valor mais crítico } \\
\text { em função do sombreamento das } \\
\text { varandas nas salas. }\end{array}$ \\
\hline 11 & Conforto olfativo & Bom & $\begin{array}{l}\text { Adequação de ambientes residenciais } \\
\text { para instalação de aparelhos que utilizam } \\
\text { gás combustível. Garantir ventilação } \\
\text { adequada conforme código de obras. } \\
\text { Identificar fontes de odores desagradáveis } \\
\text { e propor soluções no projeto para } \\
\text { minimizar o efeito. Sistema de esgoto } \\
\text { projetado para impedir que os gases } \\
\text { provenientes do interior do sistema } \\
\text { atinjam áreas de utilização. }\end{array}$ & Bom & $\begin{array}{l}\text { Adequação de ambientes residenciais } \\
\text { para instalação de aparelhos que utilizam } \\
\text { gás combustível. Garantir ventilação } \\
\text { adequada conforme código de obras. } \\
\text { Identificar fontes de odores desagradáveis } \\
\text { e propor soluções no projeto para } \\
\text { minimizar o efeito. Sistema de esgoto } \\
\text { projetado para impedir que os gases } \\
\text { provenientes do interior do sistema } \\
\text { atinjam áreas de utilização. }\end{array}$ \\
\hline 12 & $\begin{array}{l}\text { Qualidade sanitária dos } \\
\text { ambientes }\end{array}$ & Bom & $\begin{array}{l}\text { Ambientes com condições de higiene } \\
\text { específica, com revestimentos adequados } \\
\text { para facilitar a limpeza e conservação. } \\
\text { Pontos de água e esgoto e ventilação } \\
\text { natural sempre que possível. Identificação } \\
\text { das fontes emissoras de ondas } \\
\text { eletromagnéticas de baixa freqüência do } \\
\text { entorno. Identificação das fontes de } \\
\text { radiofreqüência do entorno imediato. }\end{array}$ & Bom & $\begin{array}{l}\text { Ambientes com condições de higiene } \\
\text { específica, com revestimentos adequados } \\
\text { para facilitar a limpeza e conservação. } \\
\text { Pontos de água e esgoto e ventilação } \\
\text { natural sempre que possível. Identificação } \\
\text { das fontes emissoras de ondas } \\
\text { eletromagnéticas de baixa freqüência do } \\
\text { entorno. Identificação das fontes de } \\
\text { radiofreqüência do entorno imediato. }\end{array}$ \\
\hline 13 & $\begin{array}{l}\text { Qualidade sanitária do } \\
\text { ar }\end{array}$ & * & $\begin{array}{l}\text { Garantia de ventilação permanente } \\
\text { adequada: natural (janelas) e artificial } \\
\text { (exaustão mecânica). Sem fontes externas } \\
\text { de poluição ou odores. Vias em } \\
\text { desenvolvimento podem virar pistas de } \\
\text { médio tráfego, com baixo risco sanitário. } \\
\text { Escolha de revestimentos considerando } \\
\text { emissões de COV. Necessidade de deixar } \\
\text { previsão de coifa para as cozinhas das } \\
\text { unidades para controle das fontes } \\
\text { internas de odores. }\end{array}$ & * & $\begin{array}{l}\text { Garantia de ventilação permanente } \\
\text { adequada: natural (janelas) e artificial } \\
\text { (exaustão mecânica). Sem fontes externas } \\
\text { de poluição ou odores. Vias em } \\
\text { desenvolvimento podem virar pistas de } \\
\text { médio tráfego, com baixo risco sanitário. } \\
\text { Escolha de revestimentos considerando } \\
\text { emissões de CoV. Necessidade de deixar } \\
\text { previsão de coifa para as cozinhas das } \\
\text { unidades para controle das fontes } \\
\text { internas de odores. }\end{array}$ \\
\hline 14 & $\begin{array}{l}\text { Qualidade sanitária da } \\
\text { água }\end{array}$ & Excelente & $\begin{array}{l}\text { Água potável fornecida pela } \\
\text { concessionária local, CEDAE. } \\
\text { Compromisso de projetar o sistema de } \\
\text { acordo com diretrizes AQUA - prevenção } \\
\text { dos riscos relacionados a legionelose. } \\
\text { Água pluvial coletada para irrigação. } \\
\text { Identificação das tubulações por fluxo e } \\
\text { conteúdo. Cuidados indicados no Manual } \\
\text { do Síndico. }\end{array}$ & Excelent & $\begin{array}{l}\text { Água potável fornecida pela } \\
\text { concessionária local, CEDAE. } \\
\text { Compromisso de projetar o sistema de } \\
\text { acordo com diretrizes AQUA - prevenção } \\
\text { dos riscos relacionados a legionelose. } \\
\text { Água pluvial coletada para irrigação. } \\
\text { Identificação das tubulações por fluxo e } \\
\text { conteúdo. Cuidados indicados no Manual } \\
\text { do Síndico. }\end{array}$ \\
\hline
\end{tabular}

Legenda

* Necessária a adoção de soluções construtivas diferenciadas para atendimento da certificação. 


\section{7 \\ Conclusões e sugestões para trabalhos futuros}

\section{1 \\ Conclusões}

Atualmente as incorporadoras têm buscado vantagens competitivas demonstrando preocupação com relação às questões ambientais em suas linhas de produção.

Algumas construtoras já estão buscando certificações em sustentabilidade como forma de organizar e formalizar seus processos, visando proporcionar um produto cada vez mais adequado às questões ambientais ao cliente.

Aliadas às certificações, as legislações têm tido atualizações e revisões relacionadas a esse tema.

Dentre inúmeras soluções para melhorar os processos construtivos com vistas a sustentabilidade, o estudo da alvenaria estrutural foi a base desta pesquisa.

Aliado à busca pela construção mais otimizada com prazos menores, e com custos reduzidos cresceu a quantidade de empreendimentos de padrão médio com essa solução construtiva.

Por meio desta dissertação foi possível concluir que um empreendimento em alvenaria estrutural pode trazer benefícios no âmbito da sustentabilidade, considerando-se a racionalidade do método construtivo e a economia na utilização de materiais.

Porém, alguns aspectos da qualidade do empreendimento, desconsiderando-se o sistema construtivo, podem gerar inconsistências fazendo com que o método possa ser questionado do ponto de vista de sustentabilidade. Outros sistemas estruturais podem permitir melhores soluções de projeto para o cliente, como versatilidade de plantas, soluções de fachadas, qualidade de áreas comuns, etc.

Dessa forma na decisão do partido arquitetônico deve-se levar em consideração as exigências do público alvo do empreendimento, e as decisões de projeto devem estar coerentes com o nível de qualidade exigido. 
Nem sempre a alvenaria estrutural será a solução mais adequada a determinado empreendimento, podendo gerar resultados incompatíveis com a expectativa.

Um exemplo são os produtos de alto padrão com soluções arquitetônicas mais ousadas, que irão requerer solução estrutural mais flexível e cairão em um projeto de estrutura convencional (concreto armado) e em alguns casos, em estrutura metálica. Caso contrário o produto poderá ser deficiente ou antieconômico para a classe a qual e destina.

Quando o empreendimento tem um padrão que possa ser atendido pelo sistema, os benefícios recaem sobre a incorporadora que consegue viabilizar o produto e diminui o desperdício em seus canteiros de obra, e sobre a sociedade e o meio ambiente com a redução de resíduos.

O crescimento no volume de obras de padrão popular entre 2008 e 2009 repercutiu na utilização do sistema também para empreendimentos de médio padrão.

Porém, levando-se em consideração a questão cultural, muitas construtoras têm voltado ao método em estrutura convencional como diferencial de venda.

A alvenaria estrutural traz alguns benefícios para as certificações, porém, para a maioria dos itens avaliados o sistema não apresenta grandes diferenciais.

Com relação às eficiências energética e acústica, todos os componentes deverão ser analisados e calculados em conjunto com revestimentos e esquadrias para se obter níveis mínimos determinados em norma e em certificações, o que não os destaca dos demais métodos construtivos. O maior diferencial está na racionalização da execução da obra e na redução de resíduos e no consumo de $\mathrm{CO}_{2}$.

\section{2}

\section{Sugestões}

Como sugestão para trabalhos futuros podem ser estudadas:

1) estudar as possibilidades de soluções mistas com transições (alvenaria estrutural nos tipos e embasamentos com estrutura convencional em concreto armado ou concreto protendido) de modo a se obter uma tipologia padrão ideal de construção sustentável que possa atender as 
principais certificações vigentes, e que torne o produto confortável para o cliente. Esse seria o maior desafio para as construtoras considerando-se o momento atual de constante evolução do tema, o aumento da concorrência e a preocupação com a lucratividade;

2) elaborar uma avaliação quantitativa da economia na retirada das perdas de resíduos quando da construção no sistema convencional (estrutura de concreto armado), em comparação com as perdas do sistema de alvenaria estrutural;

3) estimar, em uma primeira etapa, a economia de energia na produção dos blocos (cerâmicos e/ou de concreto) em comparação com a diminuição nas formas e no consumo de aço em um sistema estrutural em concreto armado;

4) investigar o desempenho térmico de todos os tipos de blocos com diferentes dimensões de uma parede de alvenaria estrutural para a zona bioclimática 8 , onde se insere a cidade do Rio de Janeiro, e propor soluções para atendimento às normas;

5) investigar o desempenho acústico de todos os tipos de blocos com diferentes dimensões de uma parede de alvenaria estrutural, e propor soluções para atendimento às normas. 


\section{Referências Bibliográficas}

AGOPYAN, V.; JOHN, V. M. O desafio da sustentabilidade na construção civil. Volume 5. São Paulo, Blucher. 2011.

ASSOCIAÇÃO BRASILEIRA DE NORMAS TÉCNICAS. NBR 6120: Cargas para o cálculo de estruturas de edificações, 2000.

ASSOCIAÇÃO BRASILEIRA DE NORMAS TÉCNICAS. NBR 6136: Blocos vazados de concreto simples para alvenaria, 2014.

ASSOCIAÇÃO BRASILEIRA DE NORMAS TÉCNICAS. NBR 8949: Paredes de alvenaria estrutural - Ensaio a compressão simples, 1985.

ASSOCIAÇÃO BRASILEIRA DE NORMAS TÉCNICAS. NBR 10837: Cálculo de alvenaria estrutural de blocos vazados de concreto, 2000.

ASSOCIAÇÃO BRASILEIRA DE NORMAS TÉCNICAS. NBR 15270: Componentes cerâmicos - Partes 1 e 2 - Blocos cerâmicos para alvenaria estrutural - Terminologia e requisitos, 2005.

ASSOCIAÇÃO BRASILEIRA DE NORMAS TÉCNICAS. NBR 15575: Edificações Habitacionais - Desempenho, 2013.

ASSOCIAÇÃO BRASILEIRA DE NORMAS TÉCNICAS. NBR 15873: Coordenação modular para edificações, 2010.

ASSOCIAÇÃO BRASILEIRA DE NORMAS TÉCNICAS. NBR 15961: Alvenaria estrutural - blocos de concreto, 2011.

CBIC (Câmara Brasileira da Indústria da Construção). Desenvolvimento com Sustentabilidade. Brasília, 2011.

FIB (Fédération Internationale du Béton). Bulletin 67: Guidelines for green concrete structures. Laussane, 2012.

FIGUEIRÓ, W. O. Racionalização do processo construtivo de edifícios em alvenaria estrutural. 2009 Monografia (Curso de especialização em construção civil) - Universidade Federal de Minas Gerais, Belo Horizonte.

FUNDAÇÃO VANZOLINI. Referencial técnico de certificação processo AQUA construção sustentável. Edifícios habitacionais - versão 2. São Paulo, 2013. 
FURLAN JÚNIOR, S. As principais características do projeto, dos materiais e as técnicas de execução empregadas em edifícios residenciais de alvenaria estrutural. In: $46^{\circ}$ CONGRESSO BRASILEIRO DO CONCRETO (IBRACON 2004), v. 5, pg. 40-54. Anais. Rio de Janeiro, 2004.

HENDRY, A. W. Engineered design of masonry buildings: fifty years development in Europe. Prog. Struct. Eng. Mater; 4:291-300. University of Edinburgh Scotland, 2002.

INMETRO. PORTARIA 220/13: Regulamentação Técnica para Blocos de Concreto para Alvenaria, 2013.

LINS, F. U. Análise de alternativas para melhoria do desempenho térmico de edifícios em alvenaria estrutural em face da norma brasileira 15575. Monografia (Especialização em Gerenciamento de Obras) - Universidade Tecnológica federal do Paraná, Paraná, 2012.

MAMEDE, F. C. Utilização de pré-moldados em edifícios de alvenaria estrutural. Dissertação (Mestrado em Engenharia de Estruturas) - Universidade de São Paulo, São Carlos, 2001.

MARQUES, G. S. A coordenação modular na construção civil. Monografia (Graduação em Engenharia Civil) - Universidade Veiga de Almeida, Rio de Janeiro, 2009.

MORAES, J. C. T. B. Quinhentos Anos de Engenharia no Brasil, São Paulo, 2005.

SÁNCHEZ, E. Nova normalização brasileira para a alvenaria estrutural/organização. Rio de Janeiro, 2013.

RAMALHO, M. A.; CORRÊA, M. R. S. Projetos de edifícios de alvenaria estrutural. São Paulo, PINI. 2003.

RICHTER, C. Qualidade da alvenaria estrutural em habitações de baixa renda: uma análise da confiabilidade e da conformidade. Dissertação (Mestrado em Engenharia Civil) - Programa de Pós-Graduação em Engenharia Civil, UFRGS, Porto Alegre, 2007.

TELlES, P. C. S. História da Engenharia no Brasil Século XX, Clube da Engenharia, 1984.

TELLO, R. Guia CBIC de boas práticas em sustentabilidade na indústria da construção. Brasília, 2012. 
TÉSIO, P. R. A evolução da engenharia civil no Brasil, nos últimos 100 anos, na construção e restauração de edificações históricas: o caso da estação da luz. Monografia (Graduação em Engenharia Civil) - Universidade Anhembi Morumbi, São Paulo, 2007.

YEANG, K. Proyectar com la natureza: bases ecológicas para el proyecto arquitectónico. Barcelona: GG, 1999. 


\section{Sítios consultados}

ADEMI RJ (Associação de dirigentes de empresas do mercado imobiliário). Pesquisa Ademi do Mercado Imobiliário. Disponível em: < http://www.ademi.org.br>

ARROBA CASA. Planta de cobertura do empreendimento Onda Carioca. Disponível em: $<$ http://www.arrobacasa.com.br/onda-carioca-condominium-clubrecreio/> visitado em: 30/06/2013.

ARTE LA GUIA 2000. Catedral de Reims. Disponível em: $<$ http://arte.laguia2000.com/arquitectura/atedral-de-reims $>$ visitado em: $13 / 01 / 2013$.

BANCO SANTANDER. Programa Obra Sustentável Santander. Disponível em: $<$ http://www.comunidadeobrasustentavel.com.br $>$

\section{CAIXA ECONÔMICA FEDERAL. Logomarca Selo Casa Azul - Construção sustentável. Disponível em $<$ http://abr- casa.com.br/customizados/caixa/2010/06/construcao-habitacional-ganha-guia-de- sustentabilidade-do-selo-casa-azul/> visitado em: 30/03/2013.}

CAIXA ECONÔMICA FEDERAL. Selo Casa Azul CAIXA. Disponível em: < http://www1.caixa.gov.br/popup/generico/700x450_1.asp>

COMUNIDADE OBRA SUSTENTÁVEL. Logomarca Selo Santander - Obra sustentável. Disponível em: < http://www.comunidadeobrasustentavel.com.br/blog.php?user=SistemAmbiental> visitado em: 30/03/2013.

ELETROBRÁS. Programa Procel Edifica. Disponível em: $<$ http://www.eletrobras.com/elb/procel/main.asp?TeamID=\%7BA8468F2A-58134D4B-953A-1F2A5DAC9B55\%7D>

EQUIPE DE OBRA. Exemplo de planta e legenda de projeto de alvenaria com modulação da $\mathbf{2 a}$ fiada. Disponível em: $<$ http://www.equipedeobra.com.br/construcao-reforma/59/artigo284540-1.asp> visitado em: 19/05/2013.

EVEN CONSTRUTORA E INCORPORADORA SA. Exemplo de tapume de obras com coleta seletiva. Disponível em: $<$ http://www.even.com.br/sustentabilidade/downloads/even-rs2011.pdf $>$ visitado em: 03/02/2013. 
EVEN CONSTRUTORA E INCORPORADORA SA. Perspectiva da academia do empreendimento 2. Disponível em: $<$ http://www.even.com.br/rj/rio-dejaneiro/recreio-dos-bandeirantes/residencial/luar-do-pontalresidencial?origem $=$ google \& tipo=emp $>$ visitado em: 13/04/2014.

EVEN CONSTRUTORA E INCORPORADORA SA. Perspectiva do salão de festas do empreendimento 2. Disponível em: $<$ http://www.even.com.br/rj/riode-janeiro/recreio-dos-bandeirantes/residencial/luar-do-pontal-

residencial?origem $=$ google $\&$ tipo $=\mathrm{emp}>$ visitado $\mathrm{em}:$ 13/04/2014.

EVEN CONSTRUTORA E INCORPORADORA SA. Perspectiva ilustrativa da fachada do empreendimento 2. Disponível em: < http://www.even.com.br/rj/riode-janeiro/recreio-dos-bandeirantes/residencial/luar-do-pontal-

residencial origem $=$ google $\&$ tipo $=\mathrm{emp}>$ visitado em: 13/04/2014.

EVEN CONSTRUTORA E INCORPORADORA SA. Planta baixa cobertura e Perspectiva ilustrativa do acesso do empreendimento 1. Disponível em: < http://www.even.com.br/rj/rio-de-janeiro/recreio-dos-

bandeirantes/residencial/viverde-residencial\#> visitado em: 18/05/2013.

EVEN CONSTRUTORA E INCORPORADORA SA. Planta da unidade de 3 quartos do empreendimento 2. Disponível em: $<$ http://www.even.com.br/rj/riode-janeiro/recreio-dos-bandeirantes/residencial/luar-do-pontal-

residencial origem $=$ google $\&$ tipo $=\mathrm{emp}>$ visitado em: 13/04/2014.

FUNDAÇÃO VANZOLINI. Processo AQUA (alta qualidade ambiental). Disponível em: $<$ http://www.vanzolini.org.br $>$

GREEN BUILDING COUNCIL BRASIL. Certificação internacional LEED. Disponível em: <http://www.gbcbrasil.org.br/?p=certificacao>

GRUPO BOHM. Exemplo de blocos cerâmicos. Disponível em: $<$ http://site.grupobohm.com.br> visitado em: 12/01/2013.

GRUPO SAGE. Logomarca Procel Edifica. Disponível em: < http://www.gruposage.net/public/index.php/atuacao/certificacao-2> visitado em: 30/03/2013.

LANÇAMENTOS RJ. Localização do empreendimento 1. Disponível em: $<$ http://lancamentosrj.com/imoveis-rio-de-janeiro/viverde-residencial-recreio-dosbandeirantes.html> visitado em: 13/04/2014.

LANÇAMENTOS RJ. Masterplan do empreendimento 2. Disponível em: $<$ http://www.lancamentosriodejaneiro.com/imoveis/32/Rio-de-

Janeiro/Recreio/Apartamento/Luar-do-Pontal-Apto-de-2-e-3-quartos $>$ visitado em: 13/04/2014. 
LANÇAMENTOS VIVA ANUNCIOS. Opção de ampliação da sala no empreendimento Park Premium. Disponível em: $<$ http://lancamentos.vivanuncios.com/empreendimentos+recreio/park-premiumrecreio-residences---/57700621> visitado em: 30/06/2013.

LAS VEGAS GATEWAY. Hotel Excalibur. Disponível em: $<$ http://www.lasvegasgateway.com/excalibur-hotel.html> visitado em: 13/01/2013

LOS MEJORES LUGARES. Coliseo. Disponível em: $<\mathrm{http}$ ://losmejoreslugares.galeon.com/elcoliseoromani.html $>$ visitado em: $13 / 01 / 2013$

MÃOS A OBRA. Assentamento primeira fiada. Disponível em: < http://www.maosaobra.org.br/fasciculos/fasciculo-alvenaria/alvenaria-estruturalcom-blocos-de-concreto/execucao-passo-a-passo-levantamento-da-alvenaria/> visitado em: 26/05/2013.

OLX CIDADE DO RIO DE JANEIRO. Perspectiva da academia do empreendimento Park Premium. Disponível em < http://cidaderiodejaneiro.olx.com.br/onda-carioca-condominium-club-iid$391568102>$ visitado em: 30/06/2013

OLX CIDADE DO RIO DE JANEIRO. Perspectiva da brinquedoteca do empreendimento Onda Carioca. Disponível em < $\mathrm{http}: / /$ cidaderiodejaneiro.olx.com.br/onda-carioca-condominium-club-iid$391568102>$ visitado em: 30/06/2013

OLX CIDADE DO RIO DE JANEIRO. Varanda de uma das unidades do empreendimento Minha Praia. $\quad$ Disponível em $<$ http://cidaderiodejaneiro.olx.com.br/2-quartos-jacarepagua-minha-praiasalvador-aliende-iid-499565898> visitado em: 30/06/2013

PARK PREMIUM NET. Exemplo de planta de cobertura do empreendimento Park Premium. Disponível em: <http://parkpremium.net/park-premium-recreioplantas.html $>$ visitado em: 30/06/2013.

PREFEITURA MUNICIPAL DO RIO DE JANEIRO. Selo Qualiverde legislação para construções verdes. Disponível em: $<$ http://www2.rio.rj.gov.br/smu/compur/pdf/proposta_qualiverde.pdf $>$

RECINERT AMBIENTALE. Ciclo dos resíduos da construção civil com reciclagem. Disponível em: < http://www.recinertambientale.com.br/site/?page_id=10> visitado em: 03/02/2013.

RECINERT AMBIENTALE. Ciclo dos resíduos da construção civil sem reciclagem. Disponível em: 
http://www.recinertambientale.com.br/site/?page_id=10>

visitado

em:

03/02/2013.

RECINERT AMBIENTALE. Exemplo de equipamento para a reciclagem de entulhos e resíduos da construção civil. Disponível em: < http://www.recinertambientale.com.br/site/?page_id=10> visitado em: 03/02/2013.

SCH COMPUTAÇÃO GRÁFICA. Masterplan do empreendimento 1. Disponível em: < http://www.schcg.com.br/portfolio/viverde-residencial/> visitado em: 18/05/2013.

SCH COMPUTAÇÃO GRÁFICA. Planta pavimento térreo de um dos blocos do empreendimento 1. Disponível em: < http://www.schcg.com.br/portfolio/viverde-residencial/> visitado em: 19/05/2013.

SKY SCRAPER CITY. Localização do empreendimento 2. Disponível em: $<$ http://www.skyscrapercity.com/showthread.php?t=1626777\&page $=4>$ visitado em: 13/04/2013.

SUSTENTECH. Logomarca LEED Leadership in Energy and Environmental Design. Disponível em: <http://www.sustentech.com.br/wordpress/tag/leed-ga/ $>$ visitado em: 30/03/2013

SUSTENTECH. Logomarca Processo AQUA - Construção Sustentável. Disponível em: < http://www.sustentech.com.br/wordpress/2011/10/selo-aqua-saiba-mais-sobre-a-primeira-certificacao-nascida-no-brasil/> visitado em: $30 / 03 / 2013$

UNIVERSIDADE ESTADUAL DE CAMPINAS. Núcleo de Informática Biomédica. Como redigir um trabalho científico: curso de introdução à metodologiacientífica.Disponívelem: $<\mathrm{http}: / / \mathrm{www}$.nib.unicamp.br/slides/redacao/t sld001.htm>. Acesso em 20 mar. 2001.

WDICT NET. Edifício Monadnock. Disponível em $<$ http://wdict.net/word/monadnock+bulding/> visitado em: 13/01/2013

WIKIPEDIA. All Gizah Pyramids.jpg. Disponível em: $<$ http://arz.wikipedia.org/wiki/فلف:All_Gizah_Pyramids.jpg > visitado em: 13/01/2013. 